Luciano Gosuen

\title{
Jogos e Prazeres: uma pesquisa em Infocentros de São Paulo
}

\author{
Dissertação apresentada ao Programa de Pós-Graduação \\ em Artes, Área de Concentração Artes Plásticas, Linha de \\ Pesquisa Poéticas Visuais, da Escola de Comunicações e \\ Artes da Universidade de São Paulo, como exigência parcial \\ para obtenção do Título de Mestre em Artes, sob a \\ orientação da Profa. Dra. Silvia Regina Ferreira de \\ Laurentiz.
}

\section{São Paulo} 2007 
Jogos e Prazeres: uma pesquisa em Infocentros de São Paulo

Luciano Gosuen 


\section{AGRADECIMENTOS}

Ao final deste trabalho de mestrado vejo que sua conclusão apenas foi possível através da valiosa contribuição que, diretamente e indiretamente, pessoas e instituições nos deram e que foram fundamentais para que pudéssemos nossos objetivos. Assim, gostaria de expressar os meus agradecimentos:

À professora Silvia Laurentiz, minha orientadora e amiga pela confiança que depositou em mim e pela paciência, generosidade, pelas horas de orientação e revisão deste trabalho por onde pude expandir meus conhecimentos;

Aos professores do departamento de Artes da ECA-USP Gilberto Prado e Mônica Tavares com quem pude discutir questões relevantes às poéticas digitais.

À Escola do Futuro da USP pela oportunidade, apoio financeiro (FUSP) e infra-estrutura fornecida para a realização da pesquisa de campo nos Infocentros em São Paulo;

À equipe do projeto Conexões Científicas (2004/2005), em especial às coordenadoras Daisy Grisolia e Amanelea de Campos Pinto pela dedicação na organização, análise estatística e apoio operacional e logístico para a realização da pesquisa on-line nos Infocentros em São Paulo.

A todos os usuários dos Infocentros em São Paulo que gentilmente responderam à nossa pesquisa de campo.

Aos amigos do Grupo de Poéticas Digitais da ECA-USP onde pudemos, ao longo de nossas reuniões semanais e trabalho de pesquisa, desenvolver uma base importante para nossas reflexões sobre as questões teóricas e práticas envolvendo a poética nos jogos eletrônicos.

À minha irmã, Ana Beatriz Gosuen, pela leitura e sugestões do texto.

Um agradecimento carinhoso aos meus pais Onofre e Regina, que além do incentivo e apoio fundamentais, receberam com compreensão as mudanças e deslocamentos necessários para a realização deste trabalho.

E a todas as pessoas que se arriscam a pensar o mundo através da arte, a quem dedico este trabalho. 


\section{RESUMO}

As tecnologias digitais têm permitido a construção de universos visuais, sonoros e textuais abrindo, através dos jogos eletrônicos, novas possibilidades de experimentação e construção de narrativas interativas. Nesta pesquisa procuramos buscar um entendimento mais amplo sobre como as características inerentes às narrativas digitais interativas e aos jogos eletrônicos podem, através de fatores quantitativos e qualitativos, envolver seus usuários. Para tanto, consideramos a execução de pesquisa teórica e pesquisa prática aplicadas a conceitos definidos como prazeres estéticos, a saber: imersão, agenciamento e transformação. A pesquisa prática foi direcionada para um universo específico denominado Infocentros, composto por usuários de uma comunidade que, em parte, acessam seus computadores e recursos de Internet para a prática de jogos eletrônicos.

Palavras-chave: videogames, games, jogos eletrônicos, narrativas digitais, desejo, prazer, imersão, agenciamento e transformação. 


\begin{abstract}
The digital technology has allowed the construction of visual, additive and textual universes, opening, through the videogames, new possibilities for experiment and construction of interactive narratives. In this research, we looked for a broad understanding of how the inherent aspects of the digital interactive narratives and videogames can, through quantitative and qualitative factors, involve their users. We consider the execution of a theoretical and an experimental research applied both by defined concepts such as the esthetic pleasures defined as immersion, agency and transformation. The experimental research was aimed toward a specific universe known as Infocentros, represented by user of a specific community that, in part, access their computers and internet resources for the videogame practices.
\end{abstract}

Key-words: videogames, games, electronic games, digital narrative, desire, pleasure, immersion, agency and transformation. 


\section{SUMÁRIO}

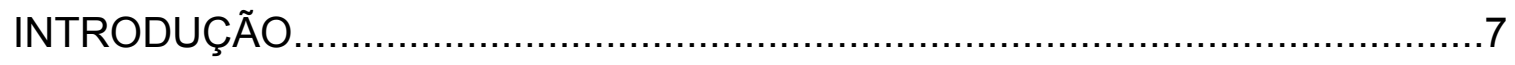

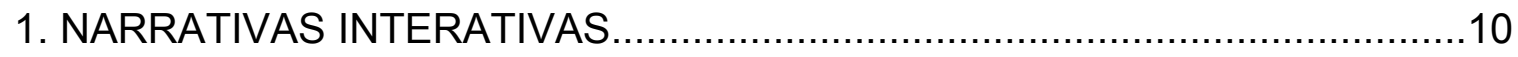

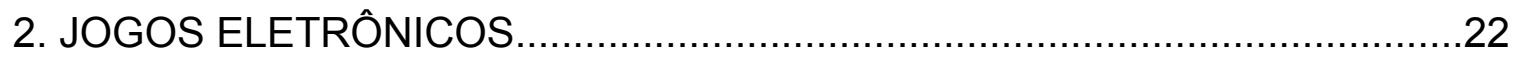

3. PESQUISA DE CAMPO: JOGOS EM INFOCENTROS DE SÃO PAULO ......39

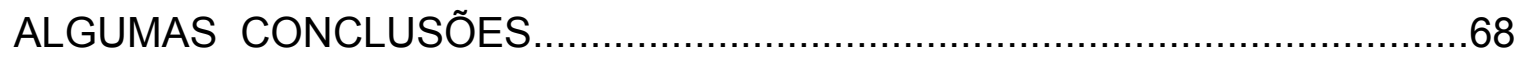

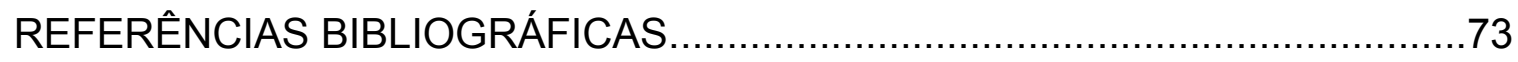

ANEXO 1. FONTES ADICIONAIS DE CONSULTA .....................................77

ANEXO 2. ATIVIDADES REALIZADAS NA PESQUISA DE CAMPO ..................80

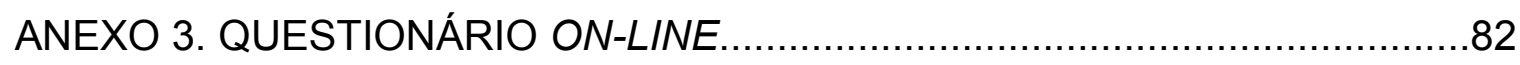




\section{INTRODUÇÃO}

A construção de ambientes virtuais interativos através de computadores parece exercer forte influência na forma pela qual expressamos idéias, dados e informações em diversas áreas como ciência, artes, educação, engenharia e comércio.

Através das tecnologias digitais podemos criar novas realidades (virtuais), explorar objetos, mundos, fenômenos e nossas habilidades para reconhecimento e experimentação de universos visuais, sonoros e táteis aplicados diretamente sobre os algoritmos computacionais.

Um dos importantes atributos oferecido pelas novas tecnologias digitais é a possibilidade na construção de conteúdo interativo. A experimentação deste conteúdo na forma de narrativas se desprende de padrões tradicionais podendo se apresentar de forma simultânea e interativa e com características participativas de interação proporcionando respostas às ações de seus interatores. A representação através destas tecnologias nos permite a construção de espaços navegáveis no qual podemos criar, mover, armazenar e recuperar informações. Um bom exemplo de espaços navegáveis são os jogos eletrônicos de computadores, popularmente conhecidos como videogames ou apenas games. As tecnologias digitais representadas pelos jogos eletrônicos e seus recursos de software e hardware podem afetar a forma como experimentamos o mundo, endereçando hoje conceitos importantes no campo das Artes Digitais e trazendo novos desafios para experimentações estéticas. Segundo Christiane Paul, os jogos eletrônicos são parte importante na história da Arte Digital onde explora muitos de seus paradigmas envolvendo conceitos que podem ir da navegação e simulação até a criação de mundos interativos virtuais e multiusuários (PAUL, 2003, p.196).

A proposta desta pesquisa segue no sentido de compor um conhecimento teórico básico sobre questões das narrativas interativas presentes no universo dos jogos eletrônicos abrindo um caminho para o entendimento sobre como estas narrativas podem envolver seus usuários através de categorias específicas de prazeres implícitas em sua lógica. Como categorias de prazeres utilizamos estritamente a denominação de prazeres estéticos relacionados às narrativas digitais interativas apresentados por Janet Murray 
(2003, p.96), não entrando em conceitos mais profundos tratados por outras áreas como a psicologia, psicanálise e filosofia. Detalharemos estas categorias no próximo capítulo e parte das considerações que Murray efetua a respeito das questões dos prazeres serão observadas em uma pesquisa de campo real.

Além do conhecimento teórico procuramos com a pesquisa um entendimento amplo sobre como as características inerentes às narrativas digitais interativas e aos jogos eletrônicos podem, através de fatores quantitativos e qualitativos tratados em pesquisa experimental de campo, envolver os usuários na prática destes jogos.

No primeiro capítulo "NARRATIVAS INTERATIVAS", tratamos como as tecnologias digitais têm permitido a construção de narrativas através da interatividade e seus atributos visuais, sonoros e textuais. Neste capítulo apresentaremos os conceitos de prazeres estéticos específicos tratados por Murray e definidos como imersão, agenciamento e transformação que serviram como base para a construção da argumentação da pesquisa de campo apresentada no terceiro capítulo "PESQUISA DE CAMPO: JOGOS EM INFOCENTROS DE SÃO PAULO".

Após tratarmos alguns atributos inerentes aos meios digitais e questões sobre as narrativas interativas, passamos para o segundo capítulo "JOGOS ELETRÔNICOS", onde procuramos entender de forma mais abrangente a relevância dos jogos eletrônicos e como estes podem envolver um rico universo de experimentação através de suas narrativas interativas.

Como forma de complementar as questões abertas no tema da pesquisa, dedicamos o terceiro capítulo "PESQUISA DE CAMPO: JOGOS EM INFOCENTROS DE SÃO PAULO", para a elaboração de uma pesquisa prática onde tivemos a oportunidade de observar o quanto os jogos eletrônicos podem envolver os jogares de uma certa população através dos conceitos apresentados nos capítulos anteriores.

Entendemos que esta dissertação, que envolve questões sobre as narrativas interativas e os jogos eletrônicos em suas características interdisciplinares não necessariamente precisaria ser conduzida no campo das artes ou da gamearte. Porém, decidimos inseri-la neste contexto por acreditarmos no potencial que alguns resultados aqui produzidos 
possam representar combustível para novas explorações poéticas no universo dos jogos eletrônicos e seus prazeres específicos.

A importância deste projeto de pesquisa não se faz apenas pela contemporaneidade do tema tratado, mas também pela necessidade de produção de conhecimento em uma área que, apesar de pouco pesquisada no Brasil, parece cada vez mais influenciar o modo como nós percebemos e nos relacionamos com o mundo de hoje. 


\section{NARRATIVAS INTERATIVAS}

As possibilidades abertas pelos meios digitais representam um ponto forte na conjunção com a natureza numérica e simbólica do universo digital para a construção e mediação do seu conteúdo. Um aspecto importante nesta conjunção é a ampla possibilidade para a simulação de experiências extraídas do mundo real em um mundo virtual. A arte dos modelos de simulação, sem dúvida, se constitui em uma arte de imagens híbridas (óticas, pintura, desenho, foto, cinema, televisão e vídeo) a partir do momento em que se encontram "numerizadas" (COUCHOT, 1993, p. 45).

Hoje, através desta tecnologia a produção atual de conteúdo digital inovador pode envolver não apenas a construção de imagens digitais mas também sons e textos interativos e parece interessar tanto ao profissional que as elaboram quanto a seu público. Na maioria de trabalhos com este tipo de conteúdo, a percepção, as dimensões temporais e espaciais parecem representar um papel decisivo no seu processo de produção podendo envolver ambientes e objetos bi e tridimensionais. Associados a recursos tecnológicos de comunicação, como a Internet, contemplariam ainda a estes universos o conceito de ubiqüidade permitindo que personagens e objetos ocupassem mais de um espaço virtual ao mesmo tempo.

"Ambientes digitais acrescidos da participação do espectador contribuem para o desaparecimento e desmaterialização da própria obra de arte substituída pela situação perceptiva: a percepção como recriação" (PLAZA, 2000, p. 14). Aos processos promovidos pela interatividade tecnológica, na relação homem-máquina, Julio Plaza postula a "abertura de terceiro grau". Esta abertura, mediada por interfaces técnicas, coloca a intervenção da máquina como novo e decisivo agente da instauração estética, própria das imagens digitais ou infográficas.

Com as tecnologias numéricas, a lógica figurativa muda radicalmente o modelo geral da figuração. Segundo o teórico Edmund Couchot, a cada ponto da imagem ótica podemos corresponder um ponto do objeto real, porém a nenhum ponto de qualquer objeto real preexistente corresponde ao pixel (COUCHOT, 1993, p. 42). Se alguma coisa preexiste 
ao pixel e à imagem, afirma Couchot, é o programa envolvendo a linguagem e os números e não mais o real, fazendo com que a lógica da figuração entre na era da Simulação.

Para Couchot, a simulação só pode tornar visível o que de antemão é inteligível. No momento em que o virtual se propõe a substituir o real, a simulação exclui toda a comunhão entre o real e o artista possibilitando assim a construção de modelos dos próprios atributos inerentes às faculdades de raciocínio, de aprendizado e emotivas do homem tornando possível a sua representação no universo digital.

Segundo Couchot desde 1970, nota-se no domínio dos meios digitais o aparecimento de algoritmos que seguem uma lógica muito diferente contemplando funções interativas inspiradas em modelos provenientes das ciências cognitivas e das ciências da vida como a genética (COUCHOT, 2003, p. 27).

A interatividade traz para as possibilidades de imagem, som e texto a capacidade de dialogar com seu criador no próprio decorrer de sua realização. Nas últimas décadas, a interatividade nos meios digitais tem sido um forte aliado para a construção de experimentos. "Dos autômatos celulares às criaturas digitais, os recursos computacionais nos oferecem hoje formas sistêmicas para simular a vida” (LAURENTIZ, 2003, p. 45). Estes sistemas podem contribuir com suas características algorítmicas e procedurais para o desenvolvimento de um curso evolutivo e adaptativo através de princípios básicos prédefinidos em sua lógica.

Neste sentido, a interatividade não se limita a permitir apenas ao espectador dialogar com o mundo digital; ela se estende aos próprios objetos virtuais simulados pelo computador. Segundo Couchot, "À interatividade exógena que se estabelecia entre o espectador e a imagem, acrescenta-se à interatividade endógena que regula o diálogo dos objetos virtuais entre eles, quer sejam bi ou tridimensionais, abstratos ou de aparência realista." (2003, p. 28-29) (ver Figura 1). Ainda segundo Couchot, através da interatividade endógena objetos virtuais podem perceber e se relacionar com outros objetos virtuais através de características próprias como forma, cor e posição. Através desta forma de interatividade, podemos construir ambientes virtuais interativos com o objetivo de simular formas sistêmicas de vidas envolvendo características evolutivas e adaptativas próprias 
conforme já mencionamos. Como exemplo, poderíamos construir em um ambiente virtual criaturas marinhas constituídas por algoritmos computacionais simples que passassem a aprender um comportamento mais complexo, como características de locomoção e alimentação, através de suas interações com outras criaturas de seu cardume e do próprio ambiente (Figura 2).

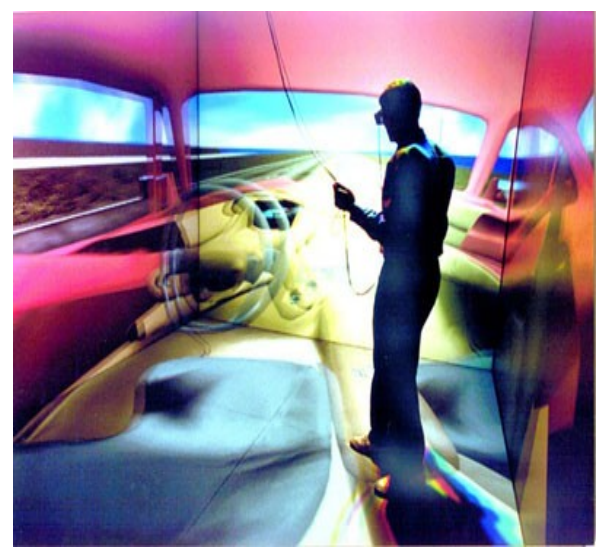

Figura 1 - Interatividade exógena. Fonte: University of Michigan 3D Lab. Disponível em: <http://um3d. dc.umich.edu/hardware/CAVE/index.html> . Acesso em: 29 jan. 2007.

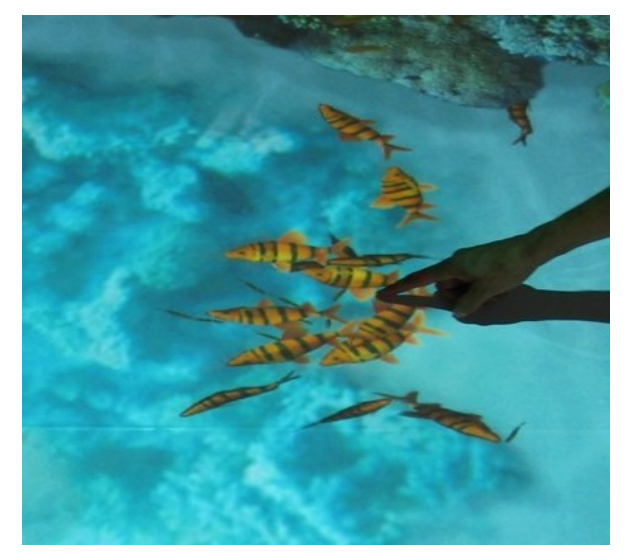

Figura 2 - Interatividade endógena. Fonte: RMH2. Disponível em: <http://www.rmh.de /fish_pool>. Acesso em: 29 jan. 2007.

Janet Murray sugere (2003, p. 96) que cada meio de expressão tem o seu próprio padrão de desejo; sua própria maneira de entender, de criar beleza, de apreender o que sentimos sobre o que é verdadeiro a respeito da vida; sua própria estética. Ao interpretarmos os meios digitais como um meio potencial para a produção de conteúdo de expressão com a produção de narrativas digitais, podemos destacar funções pelas quais este meio pode despertar o público para novos desejos e criar a demanda por uma intensificação de prazeres específicos.

Segundo Murray, "o desejo ancestral de viver uma fantasia originada num universo ficcional foi intensificado por um meio participativo e imersivo" (MURRAY, 2003, p. 101). O meio digital pode nos levar a um lugar onde podemos encenar estas fantasias. "A experiência de ser transportado para um lugar primorosamente simulado é prazerosa em si mesma, independentemente do conteúdo da fantasia. Referimo-nos a essa experiência como imersão" (MURRAY, 2003, p. 102).

Um meio digital imersivo pode envolver muitas tecnologias de gráficos interativos abrangendo dispositivos de hardware e software (Figura 3) específicos para controle e 
atualização dinâmica de movimento, som e texto. Com relação ao controle da dinâmica de movimento, os objetos podem ser visualizados e movimentados em tempo real. Para a visualização desses objetos na tela do computador ou através de projeções, o interator pode executar seus movimentos como se estivesse visualizando as imagens do ambiente virtual através de uma câmera.

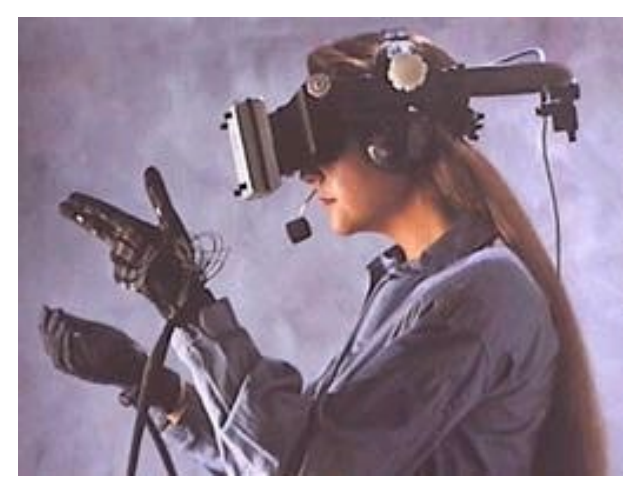

Figura 3 - Óculos esterioscópio e luvas de dados. Fonte: ErgoNetz. Disponível em: < http://www.ergonetz.de/virtualprototyping/index-e.html> Acesso em: 29 jan. 2007.

Nesse sentido, podemos contar com a movimentação da câmera permitindo uma viagem ao redor ou através dos objetos gráficos. Com a câmera fixa podemos acompanhar ou aproximar a imagem de um objeto que se movimenta. As atualizações da dinâmica de movimento no ambiente virtual estão relacionadas com as mudanças da forma, cor e outras propriedades inerentes aos objetos visualizados.

Outro aspecto presente nos meios narrativos digitais como os jogos eletrônicos, é que estes ambientes tecnológicos de imersão requerem de seu interator a aproximação de um papel como uma personagem inserida neste ambiente, com se fosse o seu sujeito. Arlindo Machado comenta que este processo de imersão ou representação do interator na tela pode ocorre de duas formas: do ponto de vista interno e externo (MACHADO, 2003, p. 177).

No primeiro caso ou ponto de vista interno (Figura 4), as imagens são mostradas na tela do interator como se este fosse visual e acusticamente o próprio personagem principal da narrativa proposta. É como olharmos através de uma câmera subjetiva como alguém que faz parte do mundo virtual dando a impressão de que experimentamos e fazemos parte da história e não apenas atuamos como um observador externo. Na segunda forma, ou seja, do ponto de vista externo (Figura 5), a navegação do interator não é dada por uma 
câmera subjetiva, mas sim por um personagem ou objeto controlado objetivamente pelo interator.

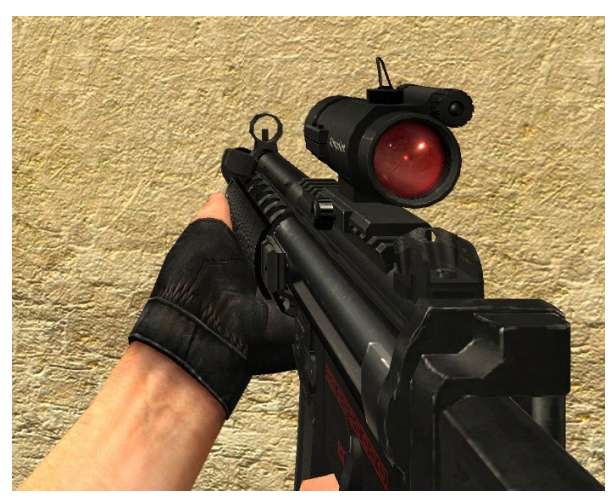

Figura 4 - Ponto de vista interno. Fonte: Conter Strike DL. Disponível em: <www. counter-strike-dl.com/ > Acesso em: 29 jan. 2007.

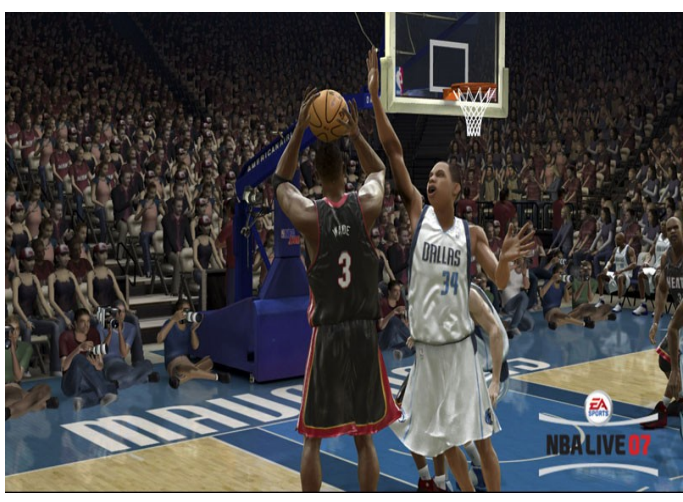

Figura 5 - Ponto de vista externo. Fonte: Electronic Arts. Disponível em: < http://www. brasil.ea.com /games/8886/screenshots/> Acesso em: 29 jan. 2007.

Estas formas de simulação, sejam subjetivas ou mais objetivas podem estar relacionadas não apenas ao nosso desejo de explorar conteúdos possíveis em nosso mundo real, mas também em explorar novas possibilidades até então impensadas. Possibilidades estas que poderiam estar evidenciadas pelo prazer de nos preservarmos através da idéia de recursividade oferecida pelo meio digital, ou seja, a possibilidade de podermos recomeçar novamente uma situação experimentada independente do seu resultado.

Uma forma de materializarmos nossas intervenções nos mundos virtuais é através dos avatares. O avatar pode ser visto como uma idéia de máscara ou bonecos. Esse conceito de avatares foi extraída da mitologia hindu na qual os corpos são representados por divindades que se materializavam quando em visita à Terra (MACHADO, 2003, p. 178179). A criação desta identidade acaba permitindo que seu possuidor esconda a sua identidade original, podendo interagir assim com outros avatares no universo virtual e mantendo seu anonimato.

Entre o universo de possibilidades oferecido pelo meio digital é permitido ao interator interferir na construção de uma narrativa através de ações significativas como resultado de uma escolha ou decisão. A esta forma de intervenção no conteúdo chamamos de agenciamento (MURRAY, 2003, p. 127) e é resultado direto das características dos sistemas interativos. 
Os universos digitais apresentam ao seu interator a possibilidade constante de mudança em sua realidade construindo uma dinâmica participativa onde as experimentações de seus conteúdos apresentam múltiplas possibilidades (Figura 6).

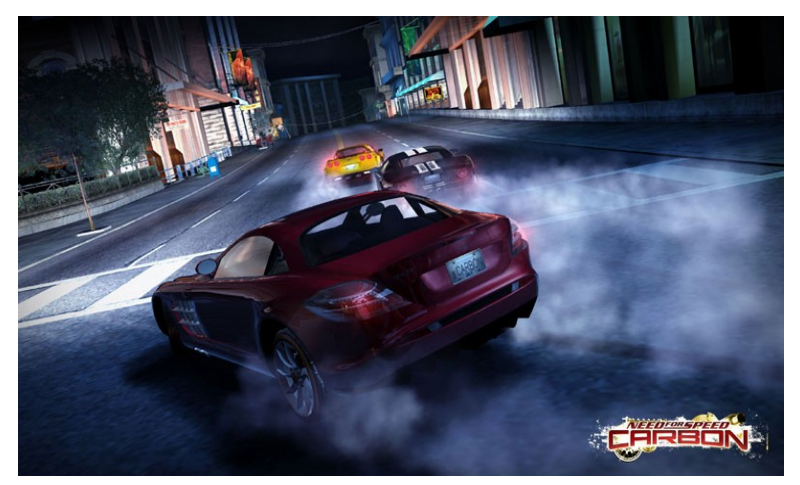

Figura 6 - Exemplo de jogo Need for Speed que demandam um alto grau de agenciamento. Fonte: Electronic Arts. Disponível em: <http:// brasil.ea.com/games/9182/screenshots/> Acesso em: 29 jan. 2007

O grau de abertura de um sistema digitalmente programado dependerá inicialmente da intenção que seu programador ou construtor expressará nas linhas de código dos programas. Porém, ficará a critério do interator o desenvolvimento da narrativa. Um bom exemplo se encontra no próprio paradigma dos jogos eletrônicos onde a maior parte das ações narrativas ocorre com a intervenção dos usuários. Uma vez que se inicia uma experiência de jogo, independente dos resultados já obtidos, inúmeras outras possibilidades de experimentação narrativa poderão ocorrer em função de como seus usuários irão agenciar suas ações. A construção de universos digitais interativos conta neste sentido com a interação de seu público para completar o trabalho iniciado pelo seu criador produzindo assim um tipo de parceria na construção da experiência ou narrativas possíveis nestes universos. Nesta relação de parceria, Murray reconhece dois modos de autoria: o autor procedimental que é aquele que deu as condições e regras para que tudo possa acontecer através do programa, e os autores das performances individuais do programa. Porém, deixa claro que não considera o interator com o autor da narrativa distinguindo a questão de autoria da questão de agenciamento (MURRAY, 2003, p. 149150).

Machado lembra (2003, p.176) que em comparação ao cinema e aos livros, nos quais sabemos que a situação narrativa foi percorrida, nos meios digitais não podemos ter esta certeza. Narrativas que dependem do agenciamento de um interator nunca têm duração definida. E neste sentido, quanto mais envolvente for a construção de uma narrativa, 
mantendo o estado imersivo de seu interator (MURRAY, 2003, p.127), mais este poderá desejar estar dentro dela. Quanto mais as coisas que fazemos neste ambiente trazem resultados tangíveis, mais podemos experimentar 0 prazer de agenciamento característico dos ambientes eletrônicos. Este prazer pode ser decorrente da capacidade gratificante de realizar ações significativas e de ver os resultados de nossas decisões e escolhas.

Seja simples ou complexo, um labirinto de aventura é especialmente apropriado para as narrativas interativas porque a história está amarrada à navegação do espaço. Conforme avançamos, podemos ter uma sensação de grande poder, agindo de forma significativa no rumo dos acontecimentos, que está diretamente relacionada ao prazer que sentimos com o desenrolar da história. Como exemplo, um possível prazer de narrativas envolvendo viagens onde tentamos alcançar algum objetivo ou destino é o de descobrir soluções para situações aparentemente sem saída. Nos jogos de computador, o contexto dramático de captura e fuga pode ser simulado pela manutenção do jogador num espaço confinado até que um enigma seja solucionado. Os enigmas ou problemas a serem resolvidos de forma mais dramática são aqueles que encorajam o interator a aplicar de forma satisfatória o raciocínio do mundo real ao mundo virtual (MURRAY, 2003, p. 138).

Um jogo eletrônico é um tipo de narração abstrata que se parece com o universo da experiência cotidiana, mas condensa esta última a fim de aumentar o interesse. "Portanto, temos uma oportunidade para encenar nossa relação mais básica com o mundo - nosso desejo de vencer a adversidade, de sobreviver às nossas inevitáveis derrotas, de modelar nosso ambiente, de dominar a complexidade e de fazer nossas vidas se encaixarem como as peças de um quebra-cabeça." (MURRAY, 2003, p. 141). Assim, embora podemos experimentar o jogo como um meio para adquirir habilidades, parece que também somos atraídos para ele pelo conteúdo expressivo implícito em sua narrativa.

Segundo Murray, a forma mais comum de jogo, a competição entre oponentes, é a forma mais recente de narrativa e está relacionada pelo principio da oposição à forma de organização da inteligência e linguagem humana (MURRAY, 2003, p. 143). Como este princípio, por intermédio de um conjunto de convenções formais o meio digital oferece um grande desafio no sentido de expressão e construções de gêneros narrativos onde são encenadas as possibilidades de mudanças em certas situações simuladas da vida. 
Além de imersão e agenciamento, outro prazer característico das narrativas interativas no ambiente digital é o da transformação. Os computadores nos oferecem incontáveis maneiras de mudanças das formas de seu conteúdo através de processos e, portanto, estão sempre nos sugerindo novas ações e eventos através de suas características numéricas. "Tudo que vemos em formato digital- palavras, números, imagens animações torna-se mais plástico, mais suscetível a mudanças." (MURRAY, 2003, p. 153). Esta característica pode se conciliar muito bem com nossos prazeres pela multiplicidade e pela variedade.

Esta é uma característica bastante similar àquilo que já denominamos de agenciamento, porém as narrativas digitais acrescentam um novo e poderoso elemento através de seu potencial transformador representado pela possibilidade de encenar histórias ao invés de simplesmente testemunhá-las. "Acontecimentos encenados têm um poder transformador que pode exceder tanto os fatos narrados quanto dramatizados, pois nós podemos assimilá-los como experiências pessoais." (MURRAY, 2003, p. 166).

As características do meio digital e seu potencial de controle sobre o conteúdo e a maneira de organização e inter-relacionamento deste, proporcionam inúmeras possibilidades narrativas. Estas possibilidades são atribuídas com a capacidade de apresentação de ações simultâneas em múltiplos formatos. Podemos projetar nossas emoções, fortemente pessoais, sobre personagens virtuais a partir de fórmulas que transferem o assunto para um campo no qual nos parece seguro pensar sobre estas emoções. Podemos trabalhar nossas fantasias, ansiedades e medos em um canal aberto em função de nossas necessidades emocionais. Com exemplo prático, existem tratamentos terapêuticos que utilizam espaços virtuais construídos especialmente para o tratamento de certas fobias, permitindo que pacientes possam iniciar um processo de cura através de certas experiências transformadoras (Figura 7). 


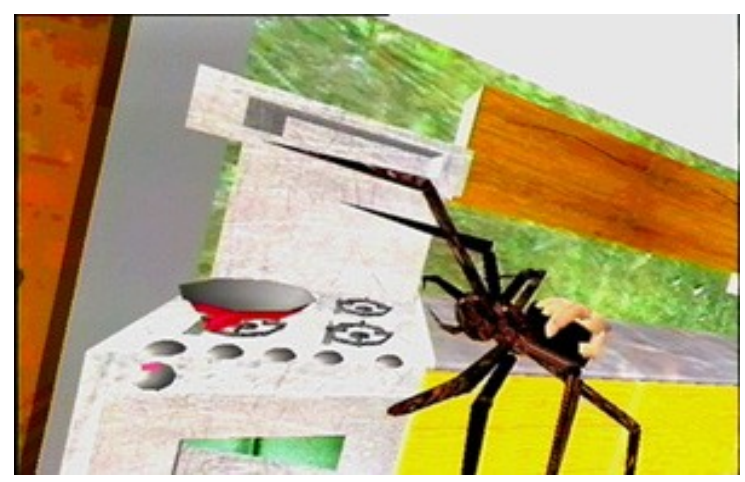

Figura 7 - Ambiente virtual denominado "SpiderWorld", desenvolvido pela Universidade de Washington, nos Estados Unidos, para o tratamento de aracnofobias. Fonte: Roland Piquepaille's Technology Trends. Disponível em: <http://www.primidi.com/2003/11/01.html>. Acesso em: 12. dez. 2006.

Quando nos defrontamos com as possibilidades de características trágicas nas narrativas digitais, como a morte de um personagem, temos a possibilidade de experimentação de um processo trágico ao contrário de apenas percorrer uma escolha trágica. Ou seja, é possível simular e então encenar uma série de possibilidades distintas que nos conduza ao mesmo destino da narrativa permitindo uma análise mais ampla sobre os aspectos implicados no fato. No computador, podemos reiniciar a história e vivenciar mais de uma vez a mesma simulação como se estivéssemos presentes novamente no mesmo processo. Existem jogos eletrônicos que possibilitam de forma bem realista a simulação de situações como o desembarque de tropas em um ambiente de guerra onde podemos vivenciar situações de perdas e morte que dificilmente experimentaríamos na vida real (Figura 8)

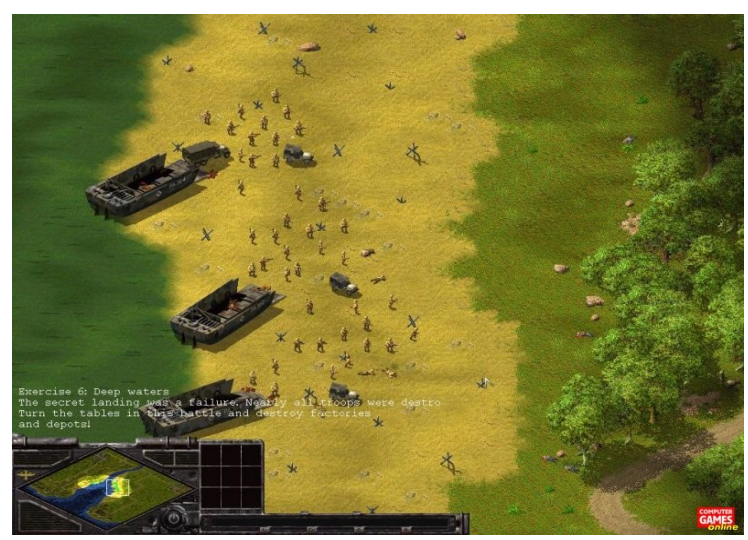

Figura 8 - Exemplo de jogos eletrônicos de simulação de guerra Sudden Strike. Fonte: Sudden Strike. Disponível em: < http://www.suddenstrike. com/index.php?uid=obj_view\&uid_cat=2828>. Acesso em: 29. jan. 2007.

Assim sendo, em mundos virtuais interativos, podemos simplesmente recomeçar incessantemente uma busca por novas formas narrativas, como experimentamos 
freqüentemente nos jogos eletrônicos, de forma a direcionar o nosso desejo pela recusa de término ou conclusão de uma experiência prazerosa.

Outra modalidade de ambientes virtuais interativos que apresenta novas possibilidades na construção e experimentação de narrativas se faz através dos ambientes virtuais multiusuários. Estes ambientes permitem que múltiplos usuários localizados em diferentes partes do planeta interajam em tempo real através de imagens 3D e som estéreo. Segundo Gilberto Prado, um sistema de ambiente virtual interativo multiusuário é composto basicamente de quatro elementos: (1) mecanismos gráficos e dispositivos de apresentação, (2) instrumentos de controle e comunicação, (3) sistemas de processamento e (4) banco de dados (PRADO, 2000). O processo imersivo dos usuários nesse mundo pode se dar através de dispositivos de hardware com teclado e mouse, máscaras, luvas dentre outros equipamentos conforme já comentamos. Sendo assim, estes ambientes podem prover seus múltiplos usuários com a habilidade de interagir uns com os outros, partilhar informação e manipular objetos no ambiente, através de imagens gráficas imersivas demandando a criação de "telepresença", ou seja, a ilusão de que os outros usuários são visíveis de locações remotas. Estes conceitos foram aplicados na obra interativa multiusuário Desertesejo (Figura 9) desenvolvida por Gilberto Prado, considerando um ambiente virtual interativo multiusuário para Internet que explora poeticamente a extensão geográfica, rupturas temporais, a solidão, a reinvenção constante e a proliferação de pontos de encontro e partilha.

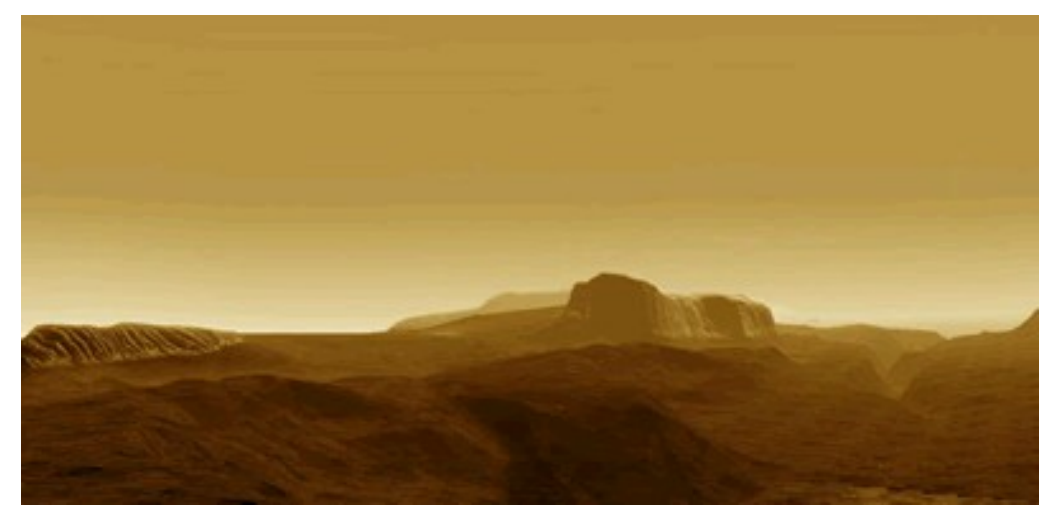

Figura 9 - Cena da obra Desertesejo. Fonte: Itaú Cultural. Disponível em: <http://www.itaucultural.org.br/desertesejo/>. Acesso em: 29. jan. 2007.

Gilberto Prado em parceria com Silvia Laurentiz ampliaram a discussão sobre a poética nos ambientes virtuais multiusuários (PRADO e LAURENTIZ, 2004, p. 24) aprofundando o olhar sobre as características já inerentes a estes meios de expressão como a criação de 
um estado de reciprocidade, ubiqüidade, partilha e simultaneidade onde se apresenta a noção do potencial de expansão do espaço partilhado e distribuído entre seus usuários. Neste potencial residem as inúmeras possibilidades de construção e criação das narrativas interativas já apresentadas, considerando porém como fator multiplicador o resultado das características multiusuário dos meios interativos.

Outro aspecto discutido pelos autores, é a noção de sessão, ou seja, o ato de construção e criação contínuas de novas narrativas interativas em uma obra através da possibilidade de se interromper e recomeçar uma narrativa, envolvendo a participação de cada indivíduo ou grupo de indivíduos. Este aspecto está relacionado a certos conceitos que sustentam a noção de transformação conforme apresentamos. O conceito de sessão também é tratado por Jim Rosenberg como paradigma para as discussões das atividades hipertextuais, onde ainda acrescenta os conceitos de actema e episódio (ROSENBERG, citado por LAURENTIZ, 2005, p. 3). Segundo Rosenberg, actema é uma unidade básica de seguir um link. Episódio é uma coleção de actemas que cria uma coerência na mente do leitor ou interator e sessão é a totalidade da atividade contínua. Através destes conceitos o autor propõe discussões sobre como o leitor ou interator podem compor a partir da experiência narrativa um processo construtivo.

Ao tentarmos entender o processo das narrativas nos jogos eletrônicos, também podemos considerar os conceitos apresentados por Andrew Rollings que sugere uma forma de construção narrativa diferente da classificação apresentada por Rosenberg (ROLLINGS, citado por LAURENTIZ, 2005, p. 4), determinando três tipos de construção. A primeira é denominada de série e representa uma seqüência limitada de capítulos, a segunda de seriado contendo uma seqüência infinita de episódios e a terceira de episodic delivery que seria algo entre uma série e um seriado. A forma onde podemos estruturar as narrativas através de construções em blocos que se desenrolam no tempo como series, seriados ou episodic delivery, nos permite conceitualmente identificar aproximações entre certos formatos construtivos dos jogos eletrônicos a outros veículos narrativos como a televisão, o cinema e a mídia impressa.

Ainda sobre formatos narrativos em ambientes multiusários de jogos, podemos citar os conceitos tratados por Singhal e Zyda que levam em consideração a construção de narrativas através de características comuns pertencentes aos ambientes multiusários. Estas características envolvem um senso partilhado de espaço, um senso de presença 
partilhada, um senso de partilha de tempo e a necessidade de uma forma de comunicação entre os participantes (SINGHAL e ZYDA, citado por PRADO e LAURENTIZ, 2004, p. 25).

Retomando a idéia de dimensão temporal e espacial citada no início deste capítulo, podemos considerar ainda que exploradores de ambientes multiusuários como a Internet, sentem-se arrebatados pela possibilidade de saltar ao redor do mundo, seguindo links de uma página ou de um site da rede para outro quase sempre pelo prazer das repetidas chegadas hipertextuais. Segundo Murray, esta duradoura atração pela navegação por caminhos que lembram labirintos pode advir da fusão entre um problema cognitivo (encontrar o caminho) e um padrão emocional simbólico envolvendo a possibilidade de enfrentamento do que é assustador e desconhecido (MURRAY, 2003, p. 130). 


\section{JOGOS ELETRÔNICOS}

Os usuários de meios digitais podem encontrar um rico campo para pesquisa e experimentação através de seus atributos considerando as possibilidades interativas apresentadas pelo computador, seus dispositivos de hardware, interface homem-máquina e principalmente 0 potencial de síntese no desenvolvimento de programas computacionais e algoritmos.

É evidente que o meio digital oferece através de suas possibilidades construtivas formas e padrões expansivos de experimentação nunca antes vividas no contexto da comunicação. Não é difícil perceber que estas possibilidades podem seguir tendências que procuram explorar questões de como percebemos o mundo real através de nossos desejos e fantasias.

As novas possibilidades abertas pelos meios digitais podem proporcionar um caminho no sentido de satisfazer as necessidades do homem em simular experiências que o ajudem a perceber e experimentar o mundo através da complexidade e da imprevisibilidade. Certamente estas possibilidades, potencializadas pelos jogos eletrônicos e seus prazeres, poderiam representar novos canais de percepção, aprendizado e expressão. Quando refletimos sobre o aparecimento dessas novas possibilidades, questões surgem com o intuito de abalar a forma sobre como essas tecnologias podem afetar nossa percepção da realidade. Essas possibilidades narrativas hoje são fortemente representadas pelos jogos eletrônicos de computadores (Figura 10).
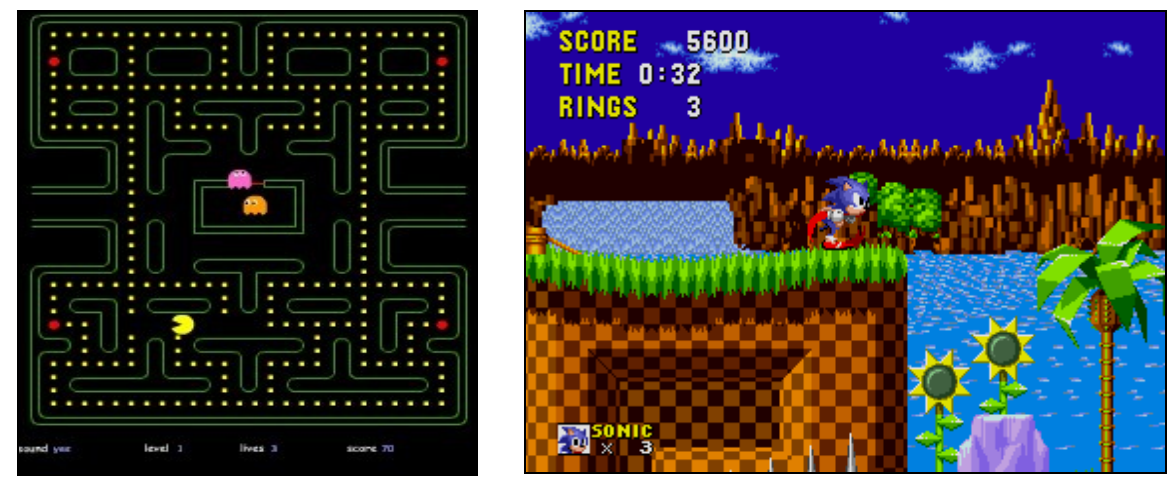

Figura 10 - Exemplo de jogos eletrônicos das décadas de 70 (Packman) e 80 (Sonic). Fonte: site Fliperama. Disponível em: < http://fliperama.uol.com.br /gamesonline>. Acesso em: 29. jan. 2007. 
Em comparação com os jogos tradicionais não eletrônicos que conhecemos como os jogos de tabuleiros, dados e cartas, nos jogos eletrônicos podemos ter a sensação de que perdemos algo como o prazer pela possibilidade física em movermos e manipularmos peças e objetos. Em compensação, nos jogos eletrônicos, suportados pelos atributos das novas tecnologias, ganhamos a possibilidade de interagir com o jogo de modo a permitir que este reaja e se adapte às nossas ações.

Inúmeros são os artigos acadêmicos e de divulgação que procuram discutir o assunto dos jogos eletrônicos. Como exemplo, reproduzimos a seguir alguns destes artigos que discutem sobre a representatividade do universo dos jogos eletrônicos e como estes têm se tornado expressivos no contexto econômico, social e cultural. Estes artigos são resultados de uma pesquisa preliminar realizada no site da Gamenet':

[...] O mercado mundial de jogos eletrônicos movimenta por ano aproximadamente US $\$ 20$ bilhões ("Mercado brasileiro é uma criança”, Valor Online, 12/11/2000). No Brasil este número é bem menor, mas não pode ser ignorado, estima-se que o mercado de jogos eletrônicos no país movimentou US\$ 500 milhões em 2000 ("Mercado brasileiro é uma criança", Valor Online, 12/11/2000) (Rafael Machado - Assessoria de Comunicação Gamenet-PR);

[...] Um artigo publicado no "Wall Street Journal" fortalece o argumento: "A indústria de videogame dos EUA é maior que a venda doméstica de ingressos para os filmes de Hollywood e está se aproximando das vendas de música", tendo acumulado US\$27 bilhões em 2002. (Hermano Vianna, Folha de São Paulo, 18/01/2004);

[...] Não foi o cinema, muito menos a música ou a literatura. O garoto-prodígio da indústria cultural em 2003 foram os games. Com plataformas de altíssima tecnologia, rendas que já ultrapassam muitas das produções de Hollywood e, sim, atores de carne e osso protagonizando os títulos, os antigos jogos eletrônicos começaram a ganhar o status de "entretenimento interativo". Alguns números para pensar: enquanto a indústria cinematográfica faturou, em 2003, US\$ 19 bilhões, os games - que já vinham de trajetória ascendente em 2002 - viraram o jogo e acumularam US\$30 bilhões no período. Quem ainda pensa que a atividade é mero passatempo de adolescentes cheios de espinhas, se surpreende ao descobrir que, ao menos nos EUA, grande parte dos jogadores é formada

\footnotetext{
${ }^{1}$ Gamenet: site especializado em jogos eletrônicos. Disponível em: <http://www.gamenetpr.com.br/>. Acesso em: 23 nov. 2004.
} 
por adultos que gastaram, segundo a revista "Fortune", 75 horas do ano na frente de um vídeo-game - tempo maior do que o gasto assistindo filmes em vídeo ou DVD. Freddi cita números: "A média de idade do gamer no Brasil é de 23 anos, e nos EUA é de 29. Trinta e sete por cento do mercado de games é sustentado por um público com mais de 40 anos. (Diejo Assis - Alexandra Matias , Folha de São Paulo , 12/01/2004);

[...] Nos últimos cinco anos, os jogos eletrônicos passaram a ocupar fatias cada vez maiores do tempo antes dedicado às opções tradicionais de lazer, como cinema, televisão e música. A velocidade é alucinante como os próprios games. Lançado em agosto, o Madden 2004, que simula partidas da NFL, a liga de futebol americano, faturou 100 milhões de dólares nas primeiras três semanas e já vendeu 1,9 milhão de cópias só nos Estados Unidos. A película Chicago, ganhadora do Oscar de melhor filme do ano passado, precisou de nove meses para atingir 171 milhões de dólares em bilheteria. O primeiro CD da banda The Strokes, um fenômeno do rock, levou dois anos para vender 1,8 milhão de cópias no mundo inteiro. O Fifa 2003, jogo que simula disputas com craques do futebol, vendeu 6 milhões de cópias em um ano, 400.000 delas no Brasil. O videogame é o tipo de produto que provoca mudanças culturais no modo como as pessoas usam o tempo livre. Lembra, em escala menor, o efeito da popularização da televisão nos anos 50 (Gabriela Carelli, revista Veja, 25/11/2003);

[...] Estima-se que existam pelo menos 3 milhões de brasileiros que freqüentem com regularidade as LANs, as lojas em que se joga em rede. "Dos vinte games mais vendidos, dezesseis estão na categoria 'everyone' e podem ser jogados por toda a família", diz a americana Ashley Vanarsdall, da Entertainment Software Association, entidade que congrega os principais fabricantes. No The Sims, o jogo mais popular do mundo, com 30 milhões de cópias vendidas, o jogador cria uma cidade, os personagens e faz o que quiser: leva-os para o trabalho e promove encontros amorosos. O segundo lugar no ranking mundial (e primeiro no brasileiro) é o Fifa, que permite dribles e esquemas táticos. Ambos são produzidos pela americana Electronic Arts, o maior fabricante mundial de videogames, que faturou 2,5 bilhões de dólares no ano passado, 40\% mais que em 2001. (Gabriela Carelli, revista Veja, 25/11/2003).

Através destes artigos percebemos a necessidade e importância de estudar, refletir e compreender melhor os jogos eletrônicos e seus possíveis impactos na sociedade, e compreender as novas dimensões e efeitos significativos que eles podem exercer no contexto sócio-cultural (ver também ANEXO 1. FONTES ADICIONAIS DE CONSULTA). 
Além de publicações de divulgação como as que acabamos de apresentar, há uma série de outras questões colocadas sobre os jogos eletrônicos sendo discutidas no âmbito acadêmico como podemos constatar através de algumas dissertações, teses e artigos já publicados sobre o assunto.

Alguns destes trabalhos podem ser encontrados disponíveis no site ${ }^{2}$ desenvolvido pelo pesquisador e desenvolvedor em jogos eletrônicos Gonzalo Frasca. Em seu site, Gonzalo também apresenta uma série de trabalhos e notícias sobre o tema e links para centros de pesquisa que estudam o assunto.

Outro site onde encontramos trabalhos sobre o assunto é o da revista eletrônica Computer Game Studies". Nesta revista, trabalhos como "Computer Game Studies, Year One" do professor Espen Aarseth da Universidade de Bergen na Noruega, "Is It Possible to Build Dramatically Compelling Interactive Digital Entertainment" do professor Selmer Brigsjord do Rensselaer Polytechnic Institute de Nova lorque e "Latin America's New Cultural Industried Still Play Old Games" do professor Jairo Lugo da Universidade John Moores na Inglaterra procuram tratar questões que abordam os jogos sobre novas possibilidades estéticas, culturais e comunicacionais.

Podemos ainda encontrar artigos publicados sobre jogos eletrônicos nos sites do International Game Developers Association ${ }^{4}$ dos Estados Unidos que divulgam informações para pessoas interessadas no assunto e o site Games, Gamers and Gaming Culture $^{5}$. Este último contêm pesquisas acadêmicas e grupos de estudos sobre jogos como os trabalhos "Computer Games as a Learning Resource" de Alan Amory, Kevin Naicker, Jackie Vicent e Claudia Adams da University of Natal da África do Sul e "Computer Games: Youth culture, resistant readers and consuming passions" de Catherine Beavis da Universidade de Deakin na Austrália.

Governos de alguns paises como os Estados Unidos têm demonstrado um maior interesse em pesquisas que buscam entender como os jogos eletrônicos podem exercer

\footnotetext{
${ }^{2}$ Disponível em: < http://www.ludology.org >. Acesso em: 23 nov. 2004.

${ }^{3}$ Disponível em: < http://www.gamestudies.org >. Acesso em: 23 nov. 2004.

${ }^{4}$ Disponível em: < http://www.igda.org/>. Acesso em: 23 nov. 2004.

${ }^{5}$ Disponível em: <http://www.knowledge.hut.fi/projects/games/gamelinks.html >. Acesso em: 23 nov. 2004.
} 
algum tipo de influência sobre a sociedade. Como exemplo o senado americano tomou a iniciativa no ano de 2000 em ouvir pesquisadores de diversos centros de pesquisas do mundo sobre o impacto nas crianças da violência interativa encontrada em jogos. $O$ resultado desta pesquisa ainda pode ser acessado no site $^{6}$ do senado americano.

O governo brasileiro, através do Ministério da Cultura, está criando iniciativas para estimular a produção de jogos eletrônicos nacionais, baseados em software livre. Segundo artigo publicado pela revista Carta Capital $^{7}$, o governo brasileiro entende que dentro da chamada economia da cultura, os jogos são importantes e precisam ser considerados no contexto da indústria audiovisual.

Com relação a trabalhos acadêmicos nacionais, encontramos publicados no site da Coordenação de Aperfeiçoamento de Pessoal de Nível Superior - CAPES, em pesquisa realizada em novembro de 2004, dezesseis teses publicadas sendo que quatro se referiam à área de educação, seis à comunicação, quatro à área de psicologia, uma à área de sociologia e uma na área de computação. Obtivemos este resultado através de uma pesquisa preliminar realizada em seu Banco de Teses", envolvendo o tema "Jogos, prazer e narrativas interativas". Como palavras-chave para esta pesquisa foram utilizadas em português: jogos eletrônicos, narrativas digitais, desejo, prazer, percepção, interface computacional, digital, interativo, cognição, aprendizagem, narrativas, virtualidades; e em inglês: games, digital narrative, electronic games, desire, pleasure, video games, computer games, user-computer interface, future of narrative, interactive narrative, interactivity, narrative, digital story e agency .

Através destas pesquisas, podemos perceber que esforços significativos no meio acadêmico começam a tomar força com o aparecimento de iniciativas investigativas voltadas para as questões relacionadas aos jogos eletrônicos. Ainda no contexto nacional, iniciativas no campo das artes para discussão sobre o tema dos jogos eletrônicos foram implementadas pelo Grupo de Pesquisa Poéticas Digitais ${ }^{9}$

\footnotetext{
${ }^{6}$ Disponível em: <http://commerce.senate.gov/press/106-141.html >. Acesso em: 23 nov. 2004.

${ }^{7}$ Disponível em: < http://cartacapital.terra.com.br/site/index frame.html>. Acesso em: 29 nov. 2004.

${ }^{8}$ Disponível em: < http://www.capes.gov.br/AgDw/frPesquisaTeses.html >. Acesso em: 19 nov. 2004.

${ }^{9}$ O Grupo Poéticas Digitais foi criado em 2002, coordenação de Gilbertto Prado e vice-coordenação de Silvia Laurentiz no Departamento de Artes Plásticas da ECA-USP. A intenção é gerar um núcleo multidisciplinar, promovendo o desenvolvimento de projetos experimentais e a reflexão sobre o impacto das novas tecnologias no campo das artes. Disponível em : < www.cap.eca.usp.br/poeticasdigitais/index.html>. Acesso em: $11 \mathrm{dez} .2006$.
} 
(ECA-USP), desenvolvendo ao longo dos anos de 2005 e 2006, pesquisa experimental envolvendo a construção de um jogo denominado "Cozinheiro das Almas" ${ }^{10}$ (Figura 11).
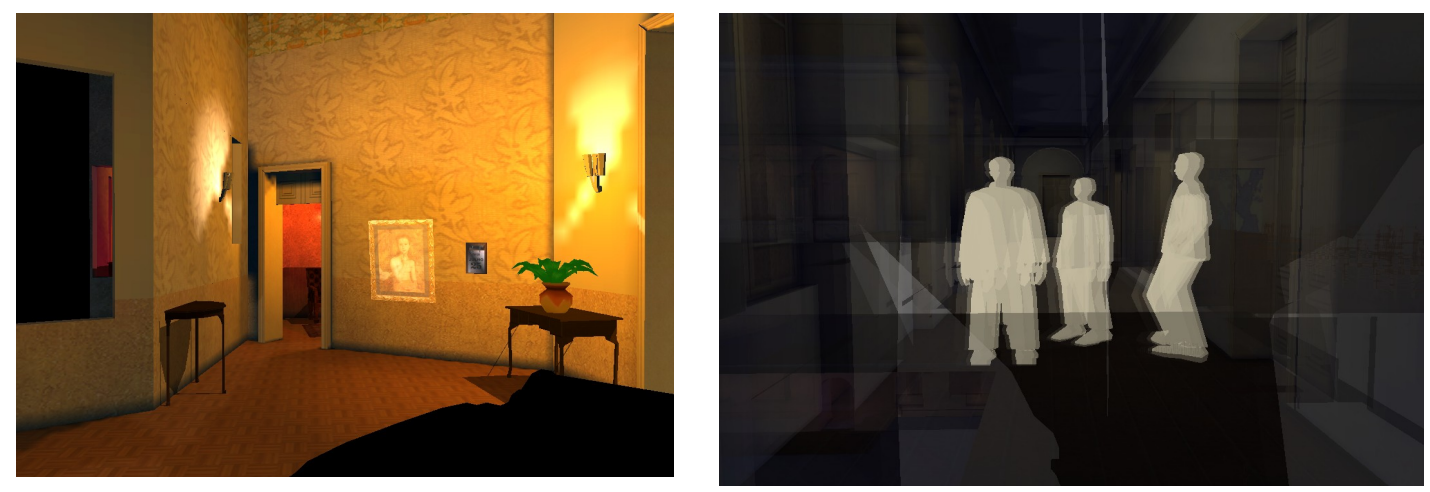

Figura 11 - Jogo eletrônico "Cozinheiro das Almas". Fonte: Grupo Poéticas Digitais ECA-USP. Disponível em: <http://www.cap.eca.usp.br/poeticasdigitais/narrativas.html>. Acesso em: 29 jan. 2007.

Também podemos citar no contexto nacional, congressos realizados com o objetivo de promover discussão sobre questões relacionadas à estética dos jogos eletrônicos. Como exemplos, o " $1{ }^{\circ}$. Congresso e Festival de Games da PUC/SP" , "1․ Festival Universitário de Games" e "10. Congresso Internacional de Estética Tecnológica" (ver outros congressos pesquisados no ANEXO 1. FONTES ADICIONAIS DE CONSULTA).

Segundo Mark Overmans em seu artigo What Is A Good Game, publicado no site

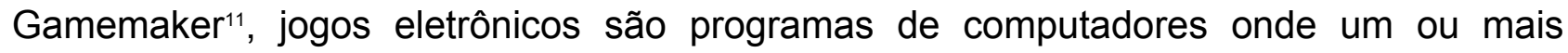
jogadores tomam decisões através do controle de seus objetos e recursos, no sentido de atingir um objetivo independente do propósito a que este jogo se destina. Atualmente os jogos eletrônicos são construídos segundo gêneros que na maioria das vezes acabam determinando como será o tipo de interação e o ritmo destes jogos. Neste sentido, imagens, sons e textos são trabalhados por seus criadores como meio de explorar a sua forma de experimentação, podendo estimular diretamente os prazeres imersivos, agenciadores e transformadores em seus jogadores (MURRAY, 2003, p. 96).

Os gêneros de jogos eletrônicos mais comuns, segundo Overmans, são:

- Árcade: jogos normalmente elaborados em duas dimensões (2D) onde a

\footnotetext{
${ }^{10}$ Cozinheiro das Almas, coordenado por Gilbertto Prado e participação de Jesus de Paula Assis, Paula Janovitch, Lívia Gabbai, Luciano Gosuen, Fábio Oliveira, Gaspar Arguello, André Furlan e Hélia Vannuchi. Disponível em: <http://www.cap.eca.usp.br/poeticasdigitais/narrativas.html>. Acesso em: 12 dez. 2006.

${ }^{11}$ Gamemaker: site especializado em jogos eletrônicos. Disponível em: <http://www.gamemaker.nl/>Acesso em: 20 jul. 2005.
} 
velocidade da reação dos jogadores é o fator mais importante. Com exemplo típico destes jogos temos o Pacman e os jogos com o conceito de mirar e atirar como o Space Invaders.

- Puzzle: onde o raciocínio é a principal características. Estes jogos também são normalmente construídos em $2 \mathrm{D}$ e o jogador joga contra o próprio computador. Como exemplo podemos citar os jogos de xadrez no computador.

- Role Playing Games (RPG): onde o jogador acompanha e guia um personagem do jogo através de um mundo cheio de obstáculos e desafios. Exemplos destes jogos são o Diablo e o Baldur's Gate.

- Estratégia: neste caso os jogadores não apenas controlam indiretamente os personagens mas também definem as estratégias gerais a que estes deverão seguir. Como exemplos temos o Age of Empires, Caesar e Theme Park.

- Aventura: neste caso a história do jogo é crucial e apesar de vários jogos deste gênero serem desenvolvidos em 3D, um grande número são jogados em 2D e utilizam o conceito de apontar, atirar ou clicar em algo. O ponto forte destes jogos não reside apenas na ação mas principalmente sobre a qualidade dos efeitos das imagens e dos sons gerados.

- Atirador em primeira pessoa (First-person shooters): Normalmente narrado através de mundos virtuais em três dimensões (3D), produz a sensação onde o jogador parece estar presente sob seu ponto de vista subjetivo no jogo. Nestes jogos são dadas ênfases na velocidade das ações e reações dos jogadores. Doom e Quake são bons exemplos.

- Atirador em terceira pessoa (Third-person shooters): onde o jogador controla diretamente um personagem através das narrativas do jogo. Estes personagens também são conhecidos como avatares. Neste tipo de jogos não existe ênfase no desenvolvimento dos personagens e sim na descoberta do mundo virtual. Exemplo: Tomb Raider.

- Jogos esportivos: onde esportes como futebol e basquete são simulados sob uma perspectiva em 2D ou 3D.

- Competição ou corrida (Racing games): Este tipo de jogo parece ser mais um tipo de jogo esportivo, mas considerando a quantidade de títulos específicos existentes acabou sendo considerado como um gênero a parte. 
Um bom exemplo são os simuladores de corrida de Formula 1 sendo que as versões mais recentes dão grande ênfase ao realismo dos efeitos especiais no jogo.

- Simuladores: Alguns destes jogos tentam simular com enorme realismo mecanismos complexos como aviões, helicópteros e submarinos dando ênfase nas habilidades dos jogadores para conhecer e controlar estes mecanismos.

Jogos baseados em textos como Dungeons and Dragons, populares nas décadas de $70 \mathrm{e}$ 80 , encontraram sua extensão para o universo das narrativas interativas nos jogos eletrônicos. Envolvendo um caráter multiusuários, podendo ser jogados em larga escala pela Internet, acabaram sendo denominados de MUD e MOO. Mais recentemente, estes jogos migraram seus conceitos narrativos para ambientes visualmente mais sofisticados (PAUL, 2003, p. 197) denominados Ultima Online (Figura 12) e Everquest (Figura 13).

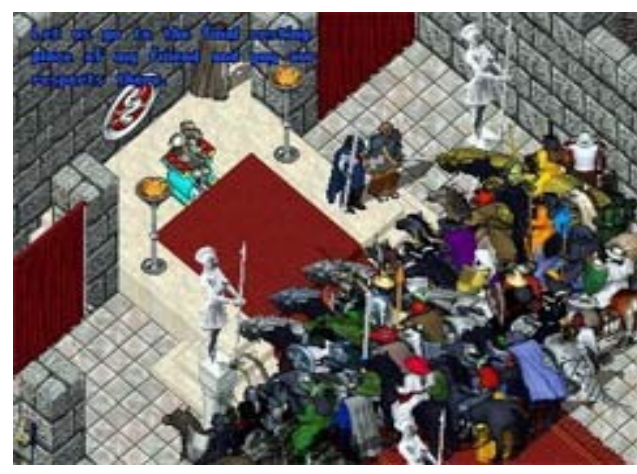

Figura 12 - Cena do jogo Ultima Online. Fonte: Ultima Online. Disponível em: $<$ http://www.uo.com/ageofshadows /viscent.html > Acesso em: 29 jan. 2007.

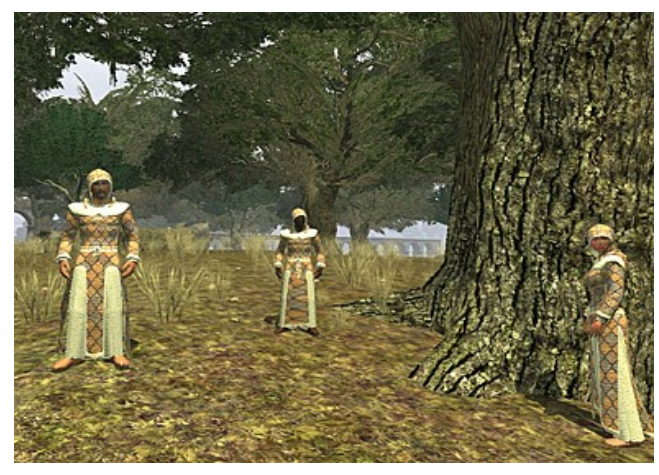

Figura 13 - Cena do jogo Everquest. Fonte: site da Station.com. Disponível em: < http:// everquest2.station.sony.com/ > Acesso em: 29 jan. 2007.

Com as possibilidades abertas pela Internet para a criação de comunidades virtuais interessadas em jogos eletrônicos, uma nova modalidade de jogo tomou força. Partindo do conceito dos jogos do gênero RPG, ambientes virtuais foram construídos para serem populados por uma quantidade de jogadores em massa que pudessem compartilhar de uma mesma experiência narrativa on-line. Esta nova modalidade ficou denominada de Massive Multiplayers On Line ou MMORPGs e pode ser jogada pela Internet por alguns milhares de jogadores ao mesmo tempo. Um exemplo desta modalidade é o jogo Ragnarok Online, criado pela empresa Sul Coreana Gravity Corp e foi baseado na 
mitologia Nórdica contendo referências às culturas Asiática, Grega e Africana.

O processo de construção de um jogo pode ser algo muito mais complexo e trabalhoso do que a própria experiência de jogar. Como exemplo, podemos citar nossa experiência no desenvolvimento em uma das etapas do jogo já mencionado "Cozinheiro das Almas". Fomos incumbidos da tarefa de construção, modelagem e animação de personagens e de alguns objetos deste jogo. Esta tarefa exigiu que desenvolvêssemos um grande repertório de conhecimentos envolvendo tanto habilidades manuais de desenho e escultura para preparação de esboços dos modelos como o conhecimento de software de modelagem 3D. Também foi necessário que tivéssemos conhecimentos sobre técnicas de modelagem para objetos e personagens 3D com menos de 700 polígonos para que pudéssemos transportá-los para um software específico onde foram implementados os ambientes e os objetos do jogo. Além de conhecimentos técnicos e habilidades, tivemos que manter um forte envolvimento com as equipes de pesquisa, roteiro e texturização dos objetos e cenários 3D do jogo.

Ao experimentarmos mais de perto como os jogos são construídos, notamos a necessidade de uma ampla estrutura sistêmica que requer o envolvimento de profissionais de diversas áreas do conhecimento. Normalmente, jogos bem elaborados demandam uma quantidade considerável de recursos de tempo, pessoas, conhecimentos, software, hardware e dinheiro. Para que estes recursos sejam adequadamente empregados na construção e integração das diversas etapas da construção de um jogo, é normal a organização de um projeto estruturado em etapas para a sua construção.

Estas etapas podem ser divididas conforme as áreas de conhecimento a saber (BETHKE, 2003, p.39):

- Design: definição do conceito, objetivo e roteiro do jogo contendo os diversos níveis desejados a serem atingidos, quais os mecanismos que integram o jogo e o desenvolvimento da história e seus diálogos.

- Programação: envolvendo conhecimentos técnicos para a definição das linhas de códigos dos jogos que permitirão a integração do jogo como um todo. Normalmente estes programas são desenvolvidos em linguagem de programação de computadores com a $\mathrm{C}$ e a $\mathrm{C}++$ e utilizam pacotes de softwares contendo bibliotecas de gráficos interativos denominados de 
engines.

- Trabalho de arte: esta etapa pode envolver o trabalho de direção de arte que coordenará toda a produção visual do jogo, o desenvolvimento dos conceitos artístico considerando rascunhos gráficos das seqüências (storyboard), pintura, texturas, escultura e desenhos que comporão o jogo. Nesta etapa, também são desenvolvidos os modelos digitais em 3D dos jogos contemplando mundos, objetos e estudo de personagens animados e efeitos visuais.

- Áudio: esta é uma etapa importante nos jogos onde os efeitos sonoros, trilhas musicais e vozes dos personagens são desenvolvidas e integradas ao resto do jogo.

- Gerenciamento: onde se busca prover financiamento para os recursos necessários à construção dos jogos, produção e administração de todas as demais etapas de construção. Esta etapa é fundamental para jogos que requerem alto grau de investimentos e recursos.

Cada uma destas etapas de construção poderá contar com equipes de profissionais dedicados no desenvolvimento de soluções específicas para o sucesso de jogo. Em jogos com produções menores, seus criadores podem assumir a responsabilidade por mais de uma etapa. Além das diversas etapas de criação tecnológica exigida na elaboração dos jogos, quando observamos a sua evolução através do tempo, suportadas por dispositivos computacionais cada vez mais sofisticados, notamos um processo natural de evolução. Este processo parece seguir uma tendência na indústria dos jogos eletrônicos, onde cada vez mais métodos criativos são empregados na construção do design e na direção de arte dos efeitos visuais buscando aprimorar, em muitos casos, o realismo atribuído na elaboração de seus mundos virtuais, personagens e objetos.

Como forma de ilustrar processos atuais de design e trabalhos de arte para os efeitos visuais empregados em certas etapas da construção de jogos, nós apresentaremos a seguir como este processo ocorreu na elaboração de um jogo específico denominado Black \& White. Este jogo foi produzido em 2001 nos Estados Unidos pela empresa Electronic Arts Inc através da produtora de jogos Lionhead ${ }^{12} \mathrm{e}$ acabou se tornando um

\footnotetext{
${ }^{12}$ Site da Lionhead com. Disponível em: <http://www.lionhead.com/teambw/makingof.html>. Acesso em: 20 jul. 2005.
} 
clássico dos jogos no seu gênero por ter sido um dos primeiros jogos a utilizar recursos de inteligência artificial, permitindo que seus personagens aprendessem com as ações e reações de seus interatores e se adaptassem a elas.

O jogo é do gênero RPG e a estratégia envolve padrões conceituais bastantes comuns para jogos desta natureza onde os jogadores tomam decisões através do controle de certos objetos no sentido de atingir um objetivo definido. $O$ objetivo do jogo é se tornar o Deus supremo dos mundos virtuais definidos.

É importante ressaltar que os jogadores não são obrigados no jogo a tomar uma posição maniqueísta escolhendo entre personagens do "bem" ou do "mau". Mesmo que nenhuma ação seja tomada pelo jogador, o jogo quando processado no computador, continuará existindo através de acontecimentos independentes e autônomos.

Quando interagimos com os objetos, personagens e cenários virtuais deste jogo, podemos notar que foram adotados cuidados no processo criativo para que fossem mantidas referências com o mundo real além de concepções fantasiosas com criaturas gigantescas (Figura 14).
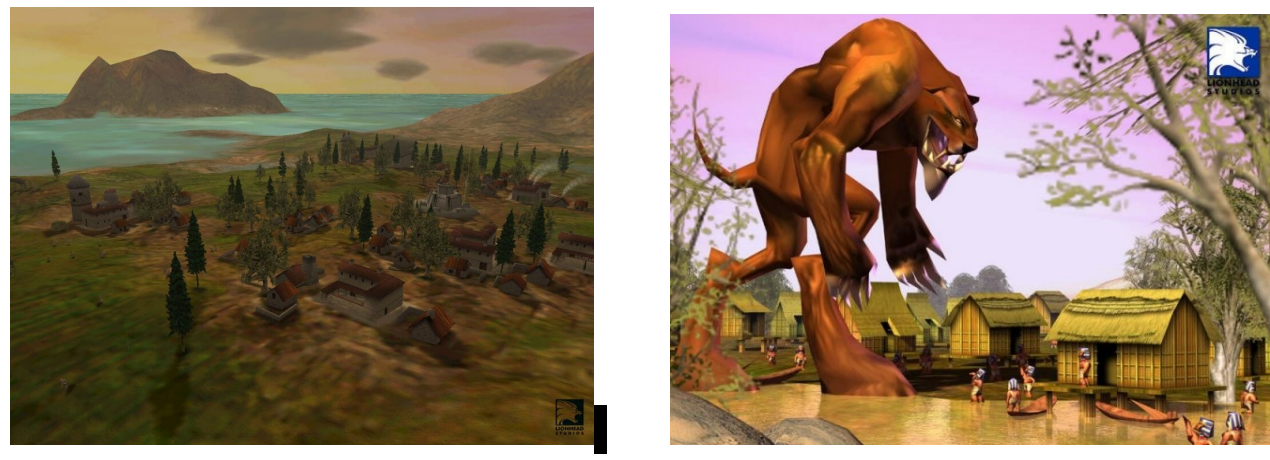

Figura 14 - Imagens realistas e fantasiosas do jogo Black \& White. Fonte: Lionhead. Disponível em: <http://www.lionhead.com/teambw/makingof.html> . Acesso em: 29 jan. 2007.

Percebemos que os criadores do jogo utilizaram referências estruturais da natureza para a construção dos ambientes virtuais. Podemos entender melhor o método de criação utilizado no jogo através de depoimentos, fornecidos no site da Lionhead, pelos profissionais envolvidos diretamente na sua criação.

Segundo o programador para a versão 2 do jogo Black \& White, Matthew Hanlon, suas florestas virtuais compreendem grande parte do cenário onde a narrativa se desenrola. 
Estas florestas foram construídas tentando simular uma situação que correspondesse à situação de uma floresta real. Assim as árvores das florestas foram divididas em árvores que se encontram em crescimento e em árvores já maduras. Para as árvores maduras foram desenvolvidos comportamentos possibilitando, sobre certas circunstâncias, a liberação de sementes que gerariam novas árvores. Este aspecto permite que as árvores possam se tornar mais independente dos jogadores, correspondendo a um conjunto de interações endógenas.

Outro aspecto interessante com relação às arvores desenvolvidas é o fato das folhagens adquirirem aspectos diferenciados em função do tempo decorrido no jogo. Para este trabalho, programadores de imagens 3D e artistas estudaram e utilizaram como fonte de inspiração as mudanças naturais que ocorrem nas árvores reais ao longo das estações do ano (Figura 15).
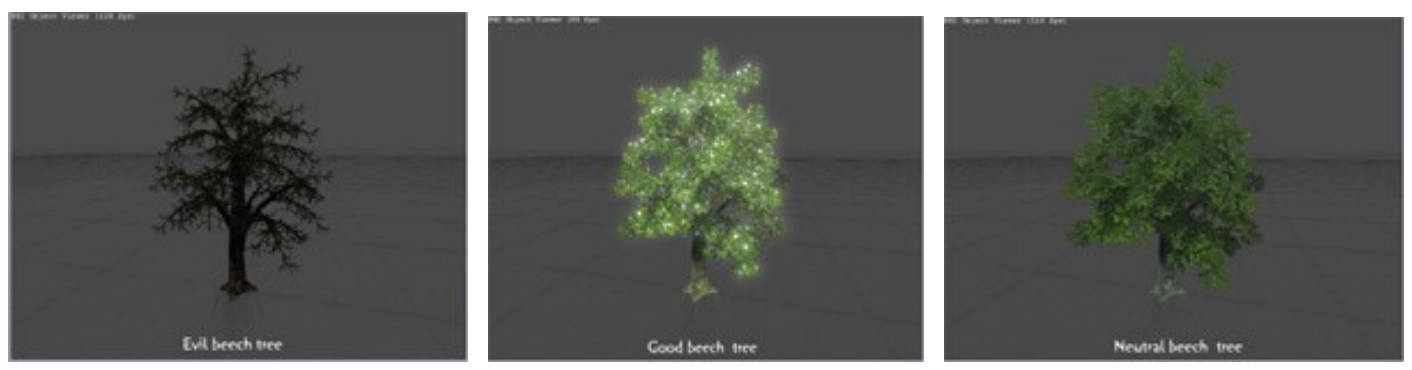

Figura 15 - Exemplo de alterações naturais empregadas em árvores virtuais no jogo. Fonte: Lionhead. Disponível em: <http://www.lionhead.com/teambw/makingof.html>. Acesso em: 29 jan. 2007.

Outro exemplo de criação de objetos com visuais elaborados no jogo é o caso do portão asteca. Neste item, os artistas comentam que se inspiraram em características reais das civilizações astecas envolvendo temas como a representação da vida, morte e renascimento para a criação do portão. A partir deste conceito, artistas desenvolveram vários outros conceitos experimentais com desenhos sobre papel, onde foram surgindo os conceitos finais para o portão. Nestes desenhos, faces representando cada um destes temas se fecham umas sobre as outras. Após esta concepção manual, as imagens foram introduzidas pelos modeladores 3D no sentido de criar modelos virtuais texturizados e animados digitalmente (Figura 16). 

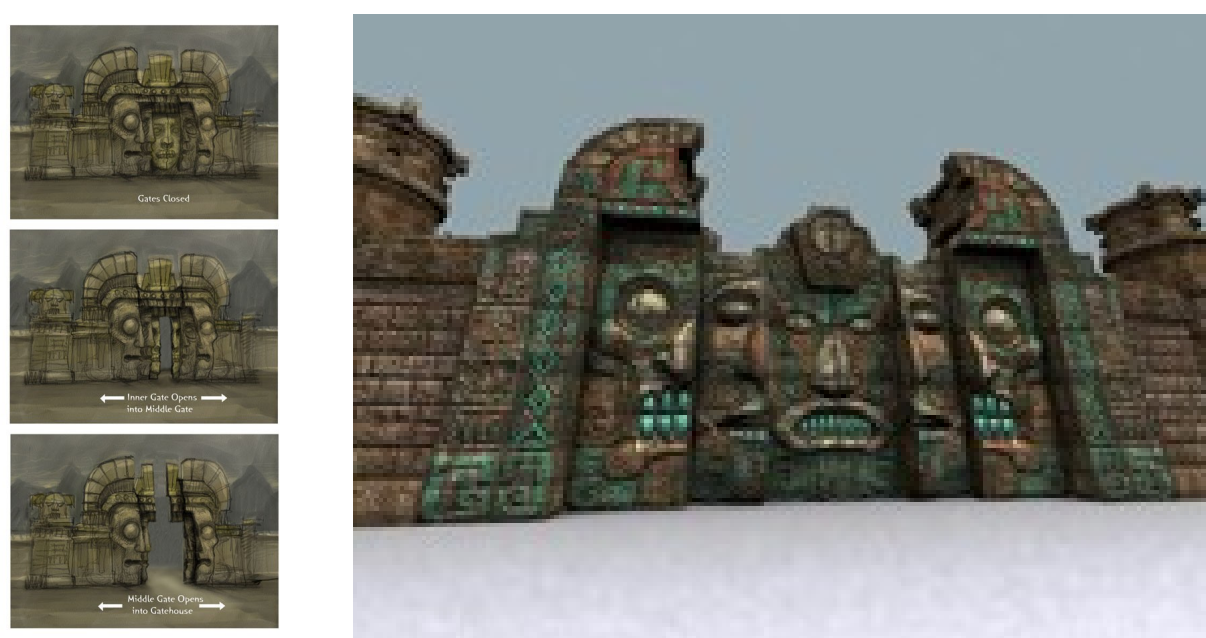

Figura 16 - Desenhos do conceito final e modelo digital do portão asteca. Fonte: Lionhead. Disponível em: <http://www.lionhead.com/teambw/makingof.html>. Acesso em: 29 jan. 2007.

O programador 3D do jogo - Francesco Carucci, comenta que em outra etapa, se inspirou em técnicas computacionais denominadas blooming ${ }^{13}$ para o auxílio na percepção de imagens brilhantes e objetos extremamente claros. Esta técnica permite a simulação, através da aplicação de filtros sobre a imagem digital, da luz que se difunde dentro do olho humano, e produz uma sensação de realismo à cena (Figura 17).
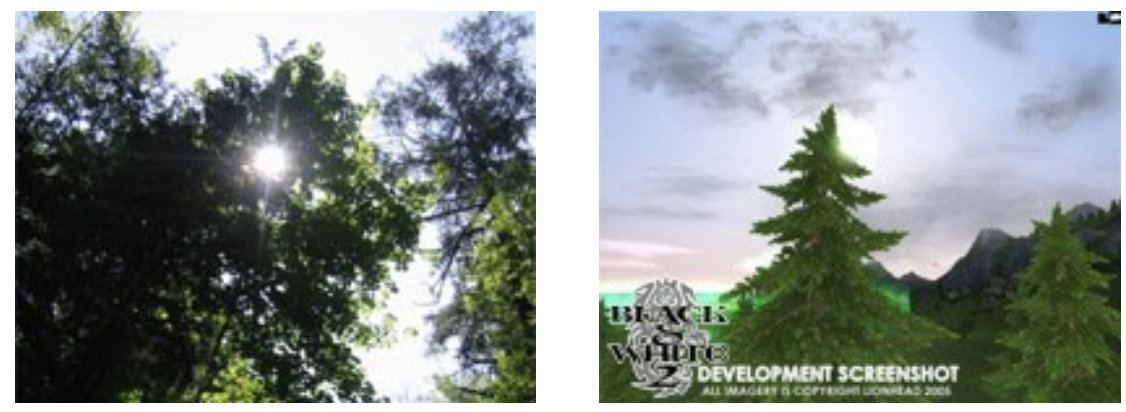

Figura 17 - Efeito blooming aplicado sobre imagens do jogo. Fonte: Lionhead. Disponível em: <http://www.lionhead.com/teambw/makingof.html>. Acesso em: 29 jan. 2007.

Para um dos roteiristas - Mattew Leonard, a maior inspiração para este jogo foi encontrada no próprio processo de jogá-lo. À medida que etapas do jogo eram construídas, ele interagia com estas como se fosse um jogador, permitindo assim que novas idéias se criassem e dessem continuação ao roteiro para as etapas seguintes.

\footnotetext{
${ }^{13} \mathrm{Em}$ alguns casos o efeito blooming produz referencias a efeitos causados pela a luz difusa quando filmada através de lentes de máquinas fotográficas ou filmadoras criando uma referência à fotografia e ao cinema.
} 
Como vimos, jogos eletrônicos podem ser considerados estruturas sistêmicas complexas, que podem envolver na sua construção profissionais como artistas, roteiristas e programadores. Assim os jogos eletrônicos estão inseridos em um contexto híbrido e podem abranger uma grande gama de recursos como programação, roteiro de navegação, design de interface, técnicas de animação (SANTAELLA, 2004).

Já no campo das artes digitais, onde investigações poéticas buscam problematizar, ou até mesmo subverter o uso das novas mídias, podemos encontrar projetos que tentam criam novos contextos para os jogos eletrônicos. Estes projetos, que também podem ser denominados de gamearte, possuem um certo caráter estético que tentam se apropriar de jogos eletrônicos de modo crítico e questionador, propondo reflexões inusitadas (LEÃO, 2005).

Como exemplo de jogos de gamearte, podemos citar o jogo multiusuário desenvolvido em 2002 pelo artista Feng Mengbo, que se apropria do sofware de um jogo eletrônico original do gênero atirador em primeira pessoa bem conhecido e chamado Quake III Arena, ou apenas Q3A, para a construção de sua obra (PAUL, 2003, P. 201). O nome de sua obra em alusão ao nome original é Q4U (Quake For You). Em seu jogo, Feng introduz sua própria imagem como o personagem principal portando uma arma e uma filmadora (Figura 18). Para os demais personagens, ele cria um exército de clones seus que podem ser jogados pelos demais jogadores. Neste contexto, o artista questiona conceitos de identidade on-line na narrativa original do jogo através de seu caráter comercial e violento.

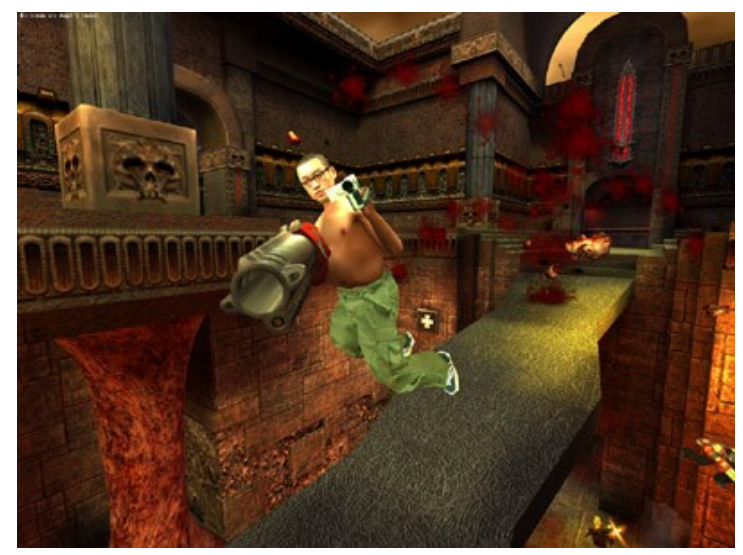

Figura 18 - Cena do jogo Q4Y. Fonte: University of Chicago. Disponível em: < http://q4u1.uchicago.edu/ >. Acesso em: 29 jan. 2007. 
Outro exemplo é o projeto de jogo Velvet-Strike desenvolvido pelos artistas Anne-Marie Schleiner, Joan Leandre e Brody Condon, como uma crítica direta à política de guerra contra o terrorismo do presidente americano George Bush. Neste projeto, os artistas se apropriam do ambiente original do jogo multiusuário, também do gênero atirador em primeira pessoa, conhecido como Counter-Strike, onde usuários podem jogar como parte de um grupo terrorista ou anti-terrorista. Através do jogo Velvet-Strike, seus jogadores podem espalhar pelas paredes e muros dos cenários virtuais do então Counter-Strike, seus grafites anti-guerra (Figura 19), desenvolvendo um conceito ativista de mídia tática (PAUL, 2003, P. 203).

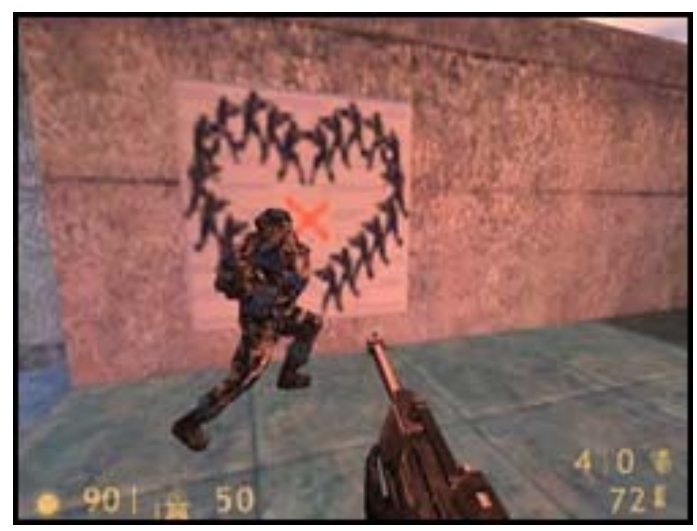

Figura 19 - Cena do jogo Velvet-Strike. Fonte: Opensorcery.net.

Disponível em: < http://www.opensorcery.net/velvetstrike/screenshots.html>. Acesso em: 29 jan. 2007.

Outro jogo desenvolvido com o conceito de gamearte foi denominado Imateriais ${ }^{14}$ (Figura 20). Este jogo foi concebido por Ricardo Ribemboim, Jesus de Paulo Assis, Celso Favaretto, Ricardo Anderáos e Roberto Moreira em 1999 (SILVA, 2004, p. 80).

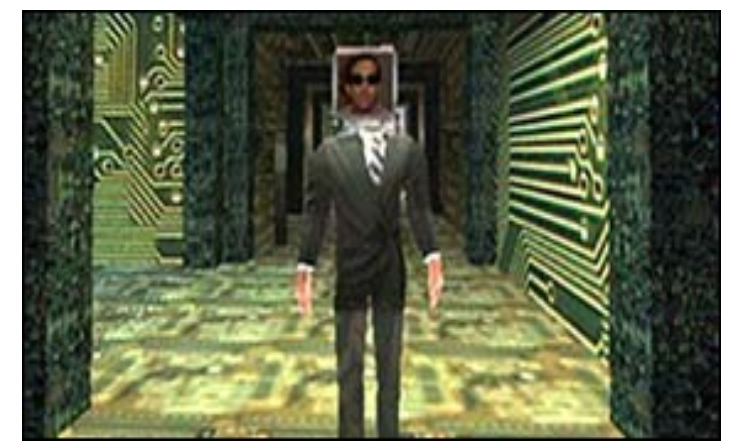

Figura 20 - Cena do jogo Imateriais. Fonte: Itaú Cultural. Disponível em: < http://www.itaucultural.org.br /index.cfm?cd_pagina=2028>. Acesso em: 29 jan. 2007.

${ }^{14}$ O jogo "Imateriais" esteve exposto no Instituto Itaú Cultural, em São Paulo em 1999. Disponível em <http://www.itaucultural.org.br/tecnica/imateriais/i01.htm>. Acesso em: 10 jan. 2006. 
É interessante notar que, diferente de jogos mais comuns, este jogo não possui um objetivo definido na sua concepção. Ao invés disto, o jogo procura explorar a interseção entre jogos eletrônicos, espaços interativos e ambientes virtuais através do envolvimento do conceito que trata da relação entre o físico, o virtual e a materialidade em um ambiente multiusuário. Se é que podemos definir um objetivo para este jogo ou ambiente virtual, este seria o de levar sensações físicas para o espaço virtual procurando explorar possíveis conexões entre o mundo físico e o virtual. Com esta intenção, foi introduzida à visitação prévia do ambiente virtual do jogo, por um percurso contínuo de ambientes físicos onde o interator podia explorar os cinco sentidos: paladar, tato, olfato, audição e visão. Estes ambientes, construídos para apresentação do jogo no Instituto Itaú Cultural, em São Paulo, se comportaram como verdadeiras instalações com o objetivo de provocar estímulos em seus interatores através da experimentação sensorial de objetos ali contidos. A idéia era que a experiência destes estímulos iniciasse a construção de uma narrativa prévia que pudesse ser transportada como experiências para o mundo virtual.

Antes que os participantes experimentassem o ambiente 3D, era preciso que cada um tirasse uma fotografia digital de seu rosto, ao qual era usada como face de seu avatar. Os criadores do jogo elaboraram aqui um conceito que permitia a mistura de imagens fotográficas com imagens virtuais dos personagens em movimento, criando assim a exploração do caráter híbrido destes ambientes navegáveis. A partir do deslocamento pelo ambiente virtual do jogo era possível conversar através de voz com outros avatares que estavam visitando a obra. A característica multiusuário do jogo permitiu que até 25 pessoas interagissem simultaneamente. Apesar de não ser considerado um jogo de aventura, seus criadores foram inspirados pelos paradigmas dos jogos de ação onde os personagens se deslocavam por labirintos virtuais como se tivessem perseguindo ou fugindo de algo.

Seja de caráter lúdico, artístico, terapêutico ou educacional o ponto forte dos jogos parece estar em seu potencial para a construção de narrativas interativas. A forma como podemos experimentar estas narrativas interativas reside no potencial impresso nos códigos de programas dos jogos idealizados pelos seus criadores conforme já mencionamos. A construção das narrativas interativas dos jogos depende tanto do potencial de criação programado, como na forma em que seus jogadores irão interagir com estes códigos através de interfaces definidas, dando continuidade ao potencial de 
criação através de um processo cíclico de recriação.

A seguir apresentaremos a pesquisa prática de campo onde procuramos identificar como, através das narrativas digitais, jogadores de uma comunidade especifica podem se sentir envolvidos pelos prazeres dos jogos eletrônicos. 


\section{PESQUISA DE CAMPO: JOGOS EM INFOCENTROS EM SÃO PAULO}

Como forma de corroborar os aspectos teóricos relacionados às narrativas interativas e seus prazeres, bem como sobre a abrangência do universo dos jogos eletrônicos já apresentados, acrescentamos nesta pesquisa uma investigação prática sobre quanto os jogos eletrônicos podem apreender e envolver os usuários de uma comunidade específica.

A pesquisa que apresentamos a seguir é resultado de nossa participação no programa Conexões Científicas ${ }^{15}$ da Escola do Futuro da USP ${ }^{16}$. Esta participação foi firmada como o objetivo de proporcionar recursos básicos necessários para a elaboração e execução de um trabalho de campo onde pudéssemos aplicar os conceitos teóricos tratados nesta dissertação, visando assim complementar e ampliar nossas bases de argumentação para as questões tratadas.

Para a execução da pesquisa nos foram disponibilizados os recursos da rede interna de computadores da Escola do Futuro dos quais obtivemos acesso às bases de dados do programa Conexões Científicas. Com o início dos trabalhos, ficamos responsáveis pela execução das atividades de campo sobre o tema "Jogos, Prazer e Narrativas Interativas" com o apoio, orientação e coordenação da Escola do Futuro. Este ciclo do programa Conexões Científicas foi coordenado pelas pesquisadoras Daisy Grisolia $^{17}$ e Anamelea de

\footnotetext{
${ }^{15}$ O programa Conexões Científica foi criado em 2003, para intensificar e ampliar a produção de conhecimento científico nas áreas de atuação da Escola do Futuro da USP. Trata-se de um sistema de gestão de pesquisa, que tem entre seus objetivos promover a interação entre diferentes setores do conhecimento, dando às pesquisas realizadas um caráter multi e trans-disciplinar. O programa seleciona alunos de pós-graduação com projetos, indicados pelos orientadores da USP, onde os pesquisadores têm a oportunidade de enriquecer e aprimorar seus projetos de pesquisa mediante a participação de atividades por meio de reuniões de atualização e acompanhamento do trabalho científico na Escola do Futuro.

${ }^{16}$ Escola do Futuro da USP é um laboratório interdisciplinar que investiga como as novas tecnologias de comunicação podem melhorar o aprendizado em todos os seus níveis. Tendo seu início em 1989 como um laboratório departamental na Escola de Comunicações e Artes, em 1993 foi transferida para o âmbito da Pró-Reitoria de Pesquisa. Disponível em: < http://www.futuro.usp.br >. Acesso em: 15 out. 2005.

${ }^{17}$ Daisy Grisolia - médica (UNIFESP 1976), psiquiatra com especialização em gestalt terapia e arte-terapia. Mestrado em Biologia molecular (UNIFESP 1980). Atua como consultora de projetos sócio-educativos em organizações públicas, privadas e do terceiro setor desde 1994. Coordenadora de pesquisa pela escola do Futuro no Programa Acessa São Paulo desde 2003.
} 
Campos Pinto $^{18}$ que proporcionaram orientação quanto ao planejamento, execução e análise dos dados quantitativos e qualitativos obtidos nos locais pesquisados. Nosso envolvimento no programa Conexões Científicas, com o objetivo de elaborarmos esta etapa da dissertação, foi iniciado em $1^{\circ}$ de setembro de 2004 e concluído em 30 de abril de 2005. Neste período dedicamos uma carga horária de aproximadamente 20 horas semanais ao projeto (ver ANEXO 2. ATIVIDADES REALIZADAS NA PESQUISA DE CAMPO).

A pesquisa de campo foi viabilizada pelo programa Conexões Científicas com o patrocínio de um outro programa denominado Acessa São Paulo ${ }^{19}$, financiado pelo Governo do Estado de São Paulo e coordenado pela Escola do Futuro.

No programa Acessa São Paulo foi identificado, através da pesquisa Ponline2004 ${ }^{20}$, um interesse crescente dos usuários em acessar jogos eletrônicos on-line em seus Infocentros ${ }^{21}$. Segundo os resultados da pesquisa, vinte e quatro por cento dos usuários acessam programas de jogos nos Infocentros ou através da Internet. Este fator foi determinante para que pudéssemos conciliar o programa Conexões a esta dissertação.

Pudemos confirmar as estatísticas apontadas na Ponline2004 através de visitas realizadas em outubro de 2004 a três destes Infocentros ${ }^{22}$ onde observamos presencialmente que em cada nove computadores disponibilizados para os usuários, pelo menos dois estavam acessando sites de jogos. Entre os sites mais procurados nos Infocentros estava o www.fliperama.com.br (Figura21) onde os usuários jogam online clássicos do gênero árcade como Pacman, Space Invaders e Sonic.

\footnotetext{
${ }^{18}$ Amanelea de Campos Pinto - Formada em Letras, Mestrado e Doutorado em Ciências da Educação pela Universidade Federal de Santa Catariana, com bolsa sanduíche na Université Nouvelle Sorbonne - Paris III. Pesquisadora Sênior na área de Educação a Distância.

${ }^{19}$ O Programa Acessa SP é uma iniciativa do Governo do Estado de São Paulo e tem como objetivo combater a exclusão digital, levando os recursos da Internet à população de baixa renda e estimulando o desenvolvimento destas comunidades. Para isso o Governo do Estado criou os Infocentros.

${ }^{20}$ Ponline2004 é a pesquisa realizada pela Escola do Futuro para o Programa Acessa São Paulo, no período de 2003/2004. Tem como objetivo principal estudar os Infocentros e os processos de Inclusão digital na população do Estado de São Paulo, por meio de um levantamento de dados, realizado on-line.

${ }^{21}$ Infocentros, espaços com acesso gratuito à Internet. Existem três tipos de Infocentros: os Infocentros Comunitários, criados em parceria com entidades comunitárias; os Infocentros Municipais, criados em parceria com prefeituras paulistas; e os Postos Públicos de Acesso à Internet, criados em parceria com órgãos do próprio Governo do Estado onde há grande fluxo de pessoas.

22 Infocentros visitados: 1) CIC Leste - Itaim Paulista, rua Pe. Virgílio Campelo, 150 - Encosta Norte; 2) Centro Comunitário Nossa Senhora Aparecida, rua Condessa Amália Matarazzo,13 - Jardim Peri; 3) Promorar São Luís, rua Cornélio Zelaia, 187 - Conjunto Promorar São Luis.
} 


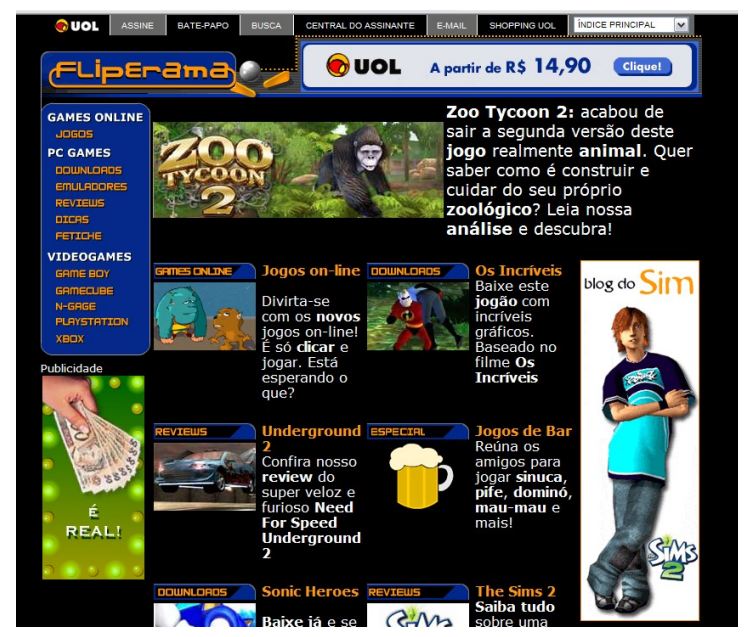

Figura 21 - Site Fliperama. Fonte: Fliperama.com.br. Disponível em: < http://www.fliperama.com.br/>. Acesso em: 29 jan. 2007.

Em uma entrevista prévia à aplicação do questionário da pesquisa com os monitores dos Infocentros, identificamos que além do site de jogos na Internet, os usuários de jogos exerciam preferência pelo jogo eletrônico Counter-Strike (Figura 22) que, conforme já mencionamos no segundo capítulo "JOGOS ELETRÔNICOS" é um jogo do gênero atirador em primeira pessoa, onde equipes de contra-terroristas e terroristas combatem até a vitória. Este é um jogo que requer muita estratégia, trabalho de equipe e habilidade para se chegar a um vencedor.
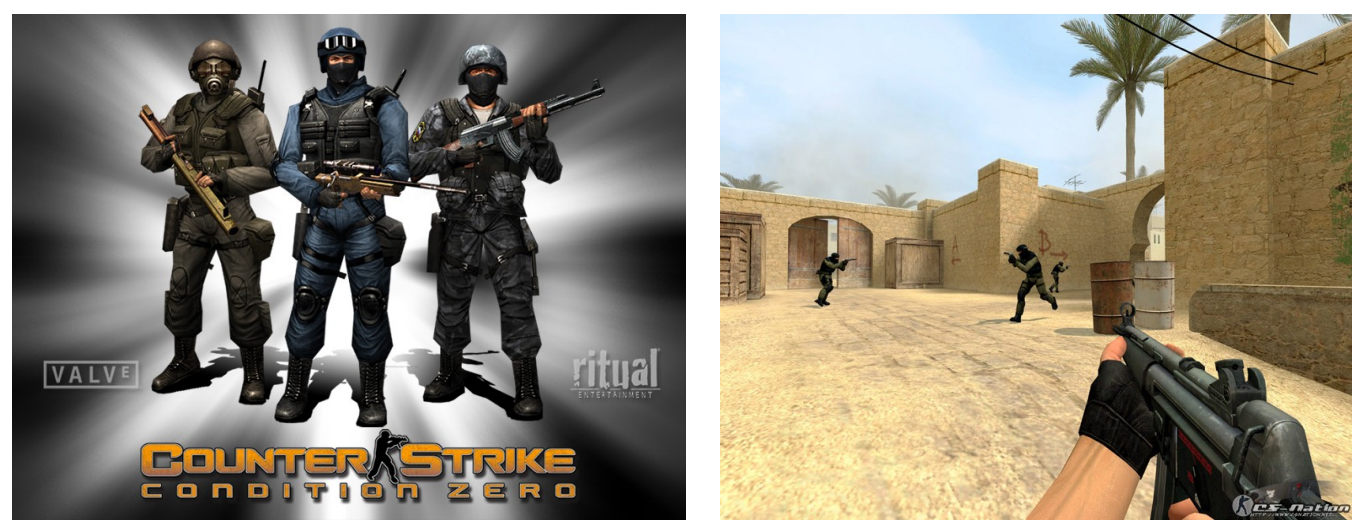

Figura 22 - Imagens do Jogo Counter-Strike. Fonte: Valve Software. Disponível em: < http://storefront .steampowered.com/v2/index.php?area=game\&Appld=240>. Acesso em: 29 jan. 2007.

Apesar de nossa pesquisa não ter sido elaborada no sentido de discutir a prática de um jogo específico, induzimos pelos comentários fornecidos pelos monitores dos Infocentros que este jogo representa um número significativo de horas de prática dedicadas pelos usuários.

Como ponto de partida para a pesquisa de campo definimos como universo e 
amostragem de análise as práticas de jogos identificadas nos Infocentros.

\begin{tabular}{|l|l|}
\hline \multicolumn{2}{|c|}{ INFORCENTROS } \\
\hline ACHAVE & Itajuibe \\
\hline ACOL & Jardim Irene \\
\hline ADEVA & Jardim Nova Progresso \\
\hline APS & Jardim Piracuama \\
\hline Associação Comunitária Tucuruvi - ACTR & Jardim São Luís \\
\hline Betinho & Luz e Vida \\
\hline Bom Prato - Santo Amaro & Mulheres da Colúmbia \\
\hline Brasil Gigante Adormecido & Mulheres do Jardim Colorado \\
\hline Butantã & Nove de Julho \\
\hline Casa de Cultura São Luis & Parque Guarapiranga \\
\hline Cenha & Pétalas de Amor \\
\hline Centro Comunitário Nossa Senhora Aparecida & Posto de Orientação Familiar - POF \\
\hline CIC Leste - Itaim Paulista & Poupatempo Santo Amaro \\
\hline CIC Norte - Jaçanã & Poupatempo Sé \\
\hline CIC Oeste - Jaraguá & Promorar São Luis \\
\hline Cidade Júlia & São Francisco de Assis \\
\hline Cio da Terra & São Judas Tadeu \\
\hline Circo Escola Grajaú & Sociedade Amigos da Vila Constança - SAVIC \\
\hline Clube da Turma do Parque Ecológico & Sociedade Amigos de Ermelino Matarazzo - SAEM \\
\hline Clube de Mães Criança Esperança & Sociedade Sonho Estudo e Ação Social \\
\hline CRI - Nova Progresso & Sol Nascente \\
\hline Criança Feliz & SUDS \\
\hline Dom Bosco & Tiradentes \\
\hline EMTU - São Mateus & Turma da Touca \\
\hline Ermelino Matarazzo - Saem & UNAS - Lagoa \\
\hline Espaço Criança Esperança & Vale Verde \\
\hline Espaço Juventude & Vila Antonieta \\
\hline Espaço Negro & Vila Cisper \\
\hline Fundação SEADE & Vila Conceição \\
\hline Gleba do Pêssego & Vila Constança - Savic \\
\hline Imprensa Oficial & Vila Nascente \\
\hline Infância Feliz & Vila Prel \\
\hline Infocentro Parq. Ecol. Guarapiranga & Vila Progresso \\
\hline Infocentro Piraporinha & Vista Alegre \\
\hline
\end{tabular}

Quadro 1 - Infocentros selecionados (68) como universo para a pesquisa de campo.

Adotamos então como objetivo inicial obter um entendimento mais apurado sobre como as características inerentes aos jogos eletrônicos podem, através de fatores quantitativos e qualitativos, envolver seus usuários na experimentação de seu conteúdo.

Para estruturar a abordagem dos tópicos da pesquisa de campo e organizar as questões colocadas aos respondentes, procuramos visualizar um diálogo sobre a experimentação do conteúdo de jogos com o intuito de propor modelos de investigação considerando o conceito estético apresentado por Janet Murray (2003, p. 96) na construção de narrativas digitais e outros pesquisadores como Arlindo Machado (2003, p. 176) e Edmond Couchot (2003, p. 27), conforme apresentados no primeiro capítulo "NARRATIVAS INTERATIVAS".

Segundo o conceito de Murray (2003, p. 96) poderíamos através dos jogos imaginar funções em suas narrativas interativas que despertam em seu público, desejos, e criam uma demanda para intensificação de prazeres específicos.

A estas categorias de prazeres de Murray (Imersão, Agenciamento e Transformação) decidimos acrescentar outra. Nesta outra categoria, que denominamos a partir de agora apenas Meio Digital, observaremos questões inerentes aos meios digitais, que embora possam estar subentendidas nas categorias de prazeres apresentadas por Murray, não 
foram explicitamente tratadas como, por exemplo: a relação dos usuários de jogos com os e os dispositivos de hardware de entrada e saída de dados; os aspectos relativos à recursividade e a portabilidade permitida para a interação com o conteúdo nos meios digitais; e as características intertextuais dos computadores que através de seus sistemas digitais interativos nos permitem experimentações simultâneas envolvendo imagens, sons e textos. Para o planejamento e seleção da amostragem desta pesquisa consideramos:

- Universo: Cidade de São Paulo - segundo o IBGE 1 são 18.386.919 residentes na Região Metropolitana ;

- População estudada: usuários cadastrados em 68 Infocentros, correspondendo atualmente à cerca de 320.000 pessoas;

- Amostra: Indivíduos da população estudada, selecionados para responder o questionário.

O processo utilizado para composição da amostragem foi a seleção aleatória simples, isto é, qualquer indivíduo da população estudada tem chances iguais de vir a ser escolhido e, uma vez selecionado, participa uma única vez da mesma pesquisa.

Quando uma pessoa era selecionada, perguntávamos se ela já havia jogado alguma vez jogos no computador. Caso sim, foi-lhe apresentado o questionário da pesquisa e esta pessoa era convidada a respondê-lo. Desse modo, todos os subgrupos existentes na população tiveram igual oportunidade de se fazer representar na amostra. Por conseguinte, tivemos também um espectro muito amplo e geral, pois, apesar das características dominantes da população que freqüenta os Infocentros, não recortamos gêneros e características sócio-culturais a serem atingidas dentro de nossa amostragem o que pode desvirtuar alguns dos objetivos que pretendíamos alcançar.

Para a definição do tamanho da amostra consideramos: a) freqüência estimada a partir da literatura e de estudos preliminares das variáveis estudadas; b) capacidade máxima de atendimento de um Infocentro; c) grau de precisão dos dados necessário para este estudo e d) recursos disponíveis em termos de tempo e custos. A seleção se deu durante uma semana típica de funcionamento dos Infocentros, em todos os horários disponíveis.

Como procedimento para seleção da amostra nos Infocentros foi atribuída a seus 
monitores a seleção dos respondentes em campo. Nas semanas de aplicação das pesquisas, todos os usuários assinaram um formulário de presença. Aqueles que a assinatura coincidiu com os números previamente selecionados foram convidados, pelo agente de pesquisa, a responder um questionário on-line. Estando o respondente de acordo, o agente de pesquisa digitava seu um número de identificação (RG, certidão de nascimento) liberando assim o sistema. Se o usuário selecionado tivesse respondido anteriormente à pesquisa, o sistema bloqueava automaticamente uma nova participação. Neste caso, o usuário seguinte era convidado a participar. Todos os respondentes preencheram um cadastro on-line com suas características sócio-demográficas: gênero, idade, etnia, estado civil, escolaridade, situação ocupacional e renda familiar.

O questionário continha dois tipos de questões específicas:

- Questões de avaliação em que o respondente indicava numa escala de 0 a 10 o seu grau de interesse com as afirmações apresentadas, sendo que 0 representa algo completamente sem interesse, e 10 algo muito interessante e prazeroso. Os respondentes tiveram ainda a opção de responder para cada uma destas questões "Não tenho opinião";

- Questões abertas onde o respondente fazia por escrito suas considerações sobre o tema da pesquisa e sobre a pesquisa em si.

Quanto ao conteúdo, as questões foram divididas em :

- Q1 a Q10 - abordando os aspectos relativos a características sóciodemográficas: gênero, sexo, idade, etnia, escolaridade, situação ocupacional, renda familiar e região da Capital São Paulo. Para as classificações de etnia, utilizamos como referência a metodologia adotada pelo Instituto Brasileiro de Geografia e Estatística - IBGE, no Censo Demográfico $2000^{23}$, que classifica a dinâmica das relações raciais na sociedade brasileira utilizando cinco categorias, a saber: branca, preta, amarela, parda e indígena;

\footnotetext{
${ }^{23}$ Censo Demográfico 2000, Disponível em: <http//www.ibge.gov.br/home/estatística/população/censo2000/ metodologia /desenho.pdf>. Acesso em 11 dez. 2006.
} 
- Q11.1 a Q11.14 - abordando grau de interesse e envolvimento dos usuários quanto aos prazeres proporcionados à categoria de prazer Meio Digital;

- Q12.1 a Q12.8 - abordando grau de interesse e envolvimento dos usuários quanto aos aspectos relacionados à categoria de prazer de Imersão;

- Q13.1 a Q13.19 - abordando grau de interesse e envolvimento dos usuários quanto aos aspectos relacionados à categoria de prazer de Agenciamento;

- Q14.1 a Q12.10 - abordando grau de interesse e envolvimento dos usuários quanto aos aspectos relacionados à categoria de prazer de Transformação;

- Q15 - comentário dos usuários quanto aos aspectos não mencionados no questionário;

- Q16 - comentário dos usuários sobre o tema da pesquisa - Jogos, Prazeres e Narrativas Interativas.

(ver ANEXO 3. QUESTIONÁRIO ON-LINE versão integral do questionário aplicado).

Para garantir a uniformidade dos procedimentos de seleção de amostra e aplicação dos questionários, os monitores dos Infocentros participaram de uma capacitação de Agentes de Pesquisa organizada a partir de atividades on-line nas modalidades síncrona e assíncrona, em três etapas, a saber:

- Distribuição on-line de material de estudo contendo os principais conceitos utilizados na pesquisa e os procedimentos a serem desenvolvidos durante a aplicação da pesquisa;

- Discussão do material de estudo através de chat com a participação de até vinte monitores por sessão, um mediador e um observador de apoio. Foram realizadas sete sessões com duração de uma hora cada, no período de um dia. Os mediadores do chat elaboraram o roteiro de discussão de modo que todas as sessões abordassem com igual ênfase os mesmos pontos;

- Plantão de dúvidas (telefone) e suporte através de fórum de discussão assíncrono - permaneceu à disposição dos monitores desde a abertura dos trabalhos até o último dia de aplicação da pesquisa.

Através do questionário procuramos observar em que intensidade as classes de prazeres aqui tratadas, poderiam envolver os usuários de jogos. Com bases nas respostas obtidas, 
primeiro tentamos efetuar as seguintes análises quando ao comportamento da população:

- Ordem das questões mais e menos votadas por média das notas;

- Percentual de indivíduos que atribuíram notas menores que 4 ou maiores que 7 ;

Na seqüência, efetuamos análise por categorias de prazeres (Meio Digital / Imersão / Agenciamento / Transformação):

- As maiores e as menores médias considerando: Infocentro, sexo, idade, escolaridade e situação ocupacional;

- As 3 maiores pontuações e as 3 menores pontuações para cada classe de perguntas;

Por fim, efetuamos análise das respostas qualitativas considerando o tipo de resposta, tempos verbais e palavras-chave utilizadas. Os questionários da pesquisa foram aplicados nos Infocentros, no período de 7 a 11 de março de 2005. Os trabalhos transcorreram sem registros de intercorrências significativas, sendo a precariedade das conexões dos computadores à Internet a dificuldade mais freqüentemente enfrentada pelos Infocentros. As respostas dos questionários foram recebidas via Internet e armazenadas em um banco de dados MYSQL. Foram eliminadas manualmente as respostas repetidas de um mesmo usuário (problemas de transmissão) e aqueles usuários que não preencheram completamente a folha de cadastro inicial e a primeira página de questões.

A pesquisa gerou um número de 273 respondentes válidos, assim distribuídos: 


\begin{tabular}{|c|c|c|c|}
\hline Gênero & $\begin{array}{l}\text { Masculino = 216 } \\
\text { Feminino }=57\end{array}$ & Renda Familiar & \multirow{2}{*}{$\begin{array}{l}\text { Menos que } 1 \text { salário mínimo }=32 \\
\text { Mais que } 1 \text { salário mínimo e até } 2 \text { salários mínimos }=104 \\
\text { Mais que } 2 \text { salários mínimos e até } 4 \text { salários mínimos }=71 \\
\text { Mais que } 4 \text { salários mínimos e até } 6 \text { salários minimos }=40 \\
\text { Mais que } 6 \text { salários mínimos e até } 8 \text { salários mínimos }=7 \\
\text { Mais que } 8 \text { salários mínimos e até } 10 \text { salários mínimos }=3 \\
\text { Mais que } 10 \text { salários mínimos }=8 \\
\text { Outros }=8\end{array}$} \\
\hline Etnia & $\begin{array}{l}\text { Branco = 103 } \\
\text { Pardos }=100 \\
\text { Pretos }=51 \\
\text { Outros }=19\end{array}$ & & \\
\hline Escolaridade & $\begin{array}{l}\text { Ensino Fundamental = } 109 \\
\text { Ensino Médio }=135 \\
\text { Ensino Superior }=14 \\
\text { Outros }=15\end{array}$ & \multirow[t]{3}{*}{$\begin{array}{l}\text { Pessoas da } \\
\text { família }\end{array}$} & \multirow{3}{*}{\begin{tabular}{|l|} 
Duas $=15$ \\
Três $=35$ \\
Quatro $=68$ \\
Cinco $=62$ \\
Seis $=39$ \\
Sete $=29$ \\
Oito $=7$ \\
Nove $=6$ \\
Dez $=2$ \\
Mais de $10=10$
\end{tabular}} \\
\hline $\begin{array}{l}\text { Situação } \\
\text { Ocupacional }\end{array}$ & $\begin{array}{l}\text { Estudam e trabalham }=28 \\
\text { Não estudam e trabalham }=135 \\
\text { Estudam e não trabalham }=41 \\
\text { Não estudam e não trabalham }=41 \\
\text { Outros }=9\end{array}$ & & \\
\hline $\begin{array}{l}\text { Região da } \\
\text { Capital (SP) }\end{array}$ & $\begin{array}{l}\text { Centro }=2 \\
\text { Leste }=127 \\
\text { Norte }=20 \\
\text { Sul }=119 \\
\text { Outros }=5\end{array}$ & & \\
\hline
\end{tabular}

Quadro 2 - Totais de respondentes nos Infocentros por gênero, etnia, escolaridade, situação ocupacional, região da Capital de São Paulo, renda familiar e pessoas da família.

Os dados foram exportados para uma planilha no software Excell a partir da qual foram realizados os cálculos de freqüência de resposta, distribuição por subgrupos, média e desvio padrão para as questões avaliadas na escala de 0 a 10;

A análise estatística dos dados foi o instrumento utilizado neste trabalho para quantificar e conhecer melhor os seguintes aspectos:

- As características sócio-demográficas dos usuários dos Infocentros;

- A distribuição, entre diferentes subgrupos da população, de hábitos, atitudes e as preferências com relação aos jogos eletrônicos;

- O envolvimento dos usuários em relação ao seu grau de interesse pelos jogos eletrônicos em função das classes de prazeres previamente definidas.

Números, gráficos e análises estatísticas nos ajudaram a construir um mapa da realidade em termos de distribuição, intensidade e freqüência de respostas. Os dados quantitativos são base para os indicadores do acompanhamento sistemático e periódico de evolução de um determinado fenômeno grupal. Contudo, eles são apenas uma representação particular de uma realidade complexa, formada a partir dos pressupostos (recortes) do pesquisador, do especialista em estatística e de sua cultura.

Os textos produzidos pelos usuários nas questões abertas, nos deram indicações sobre os afetos e sentimentos atribuídos ao ato de jogar que, de forma genérica, nos indicam caminhos na elaboração de novas questões específicas não consideradas 
anteriormente. Como exemplo, podemos citar a resposta atribuída por um dos respondentes à questão 16 , onde são solicitados a comentarem livremente sobre o tema da pesquisa: "Eu acho que um jogo perfeito é aquele que nos diverte, mas que nos ensina a viver também. Nos mostre cultura".

Quando partimos para a análise dos resultados obtidos na pesquisa quantitativa, observamos que a grande maioria dos respondentes se constitui de usuários dos próprios Infocentros das regiões Leste (47\%) e a região Sul (49\%) da Capital de São Paulo. Nesta amostra, podemos identificar ainda que a maioria, ou seja, $78 \%$ dos usuários, eram representados por pessoas do sexo masculino e $21 \%$ por pessoas do sexo feminino.

As pessoas de etnia branca e parda representaram $75 \%$ da população dos respondentes e representam pessoas que pertencem na maioria $(89 \%)$ à rede de ensino fundamental de $5^{\mathrm{a}}$ a $8^{\mathrm{a}}$ série e ensino médio, com uma representatividade de $38 \%$ e $51 \%$, respectivamente, conforme demonstrados nos gráficos:

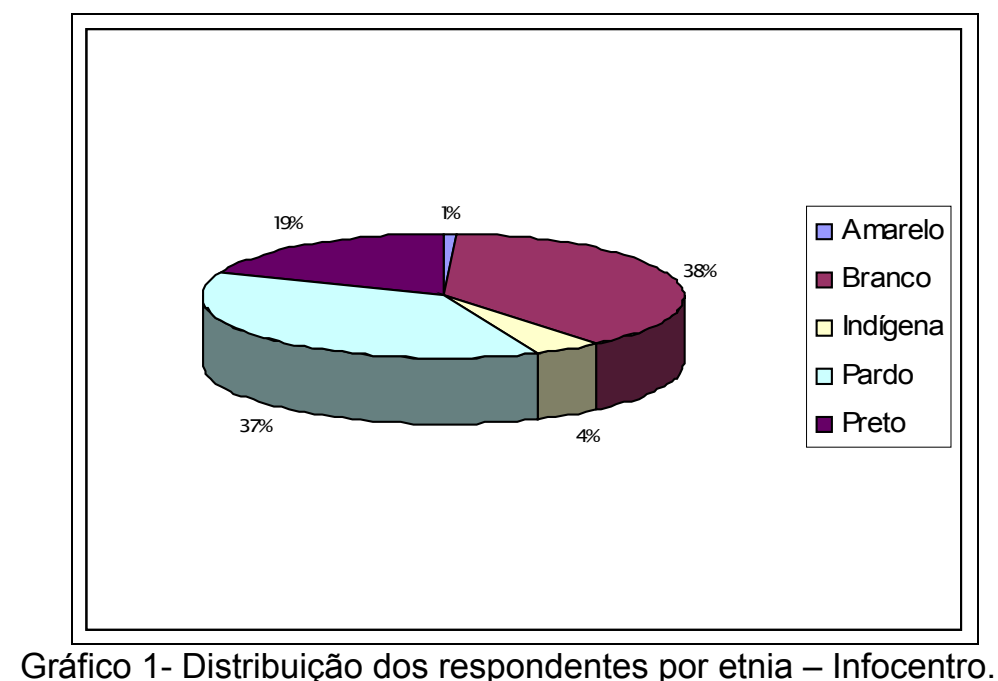




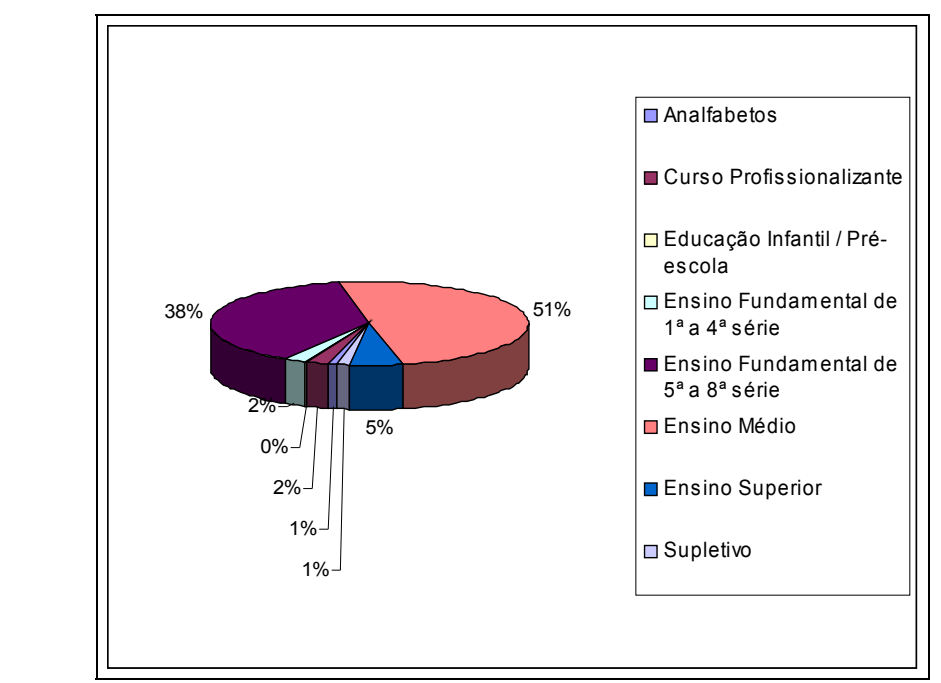

Gráfico 2- Distribuição dos respondentes por escolaridade - Infocentros.

A maioria dos respondentes, somando um total de $32 \%$, possui entre 15 e 18 anos de idade, seguidos de respondentes entre 11 e 14 anos de idade (23\%).

A situação ocupacional destes respondentes mostra que a maioria atualmente é representada por pessoas que estudam $(73 \%)$ e que não trabalham $(77 \%)$, conforme o gráfico:

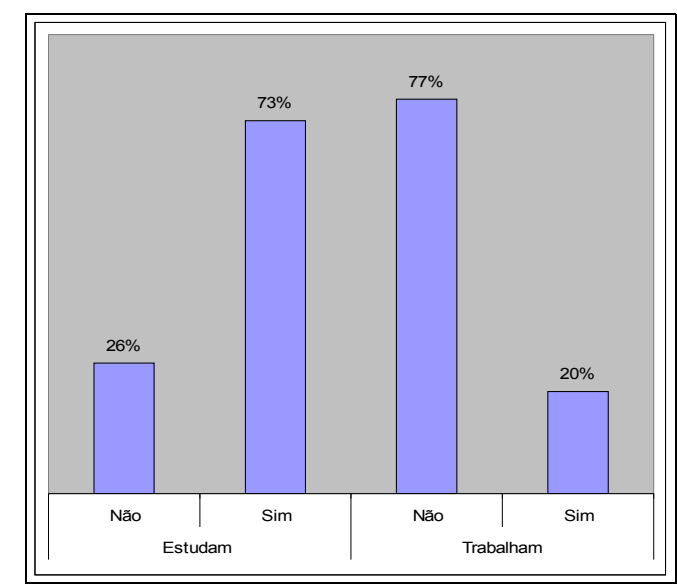

Gráfico 3 -Situação ocupacional dos respondentes - Infocentros.

Sobre um ponto de vista geral, e com o objetivo de entender o comportamento dos usuários de jogos eletrônicos, foram elaboradas 51 questões sobre as categorias específicas de prazeres nos jogos. Através das respostas obtidas, observamos um resultado onde consta que as quatro maiores médias foram atribuídas às questões 14.5, $14.4,13.3,13.13$ e as quatro menores às questões $11.1,11.2,11.5,11.9$, pontuadas conforme mostra o gráfico a segui: 


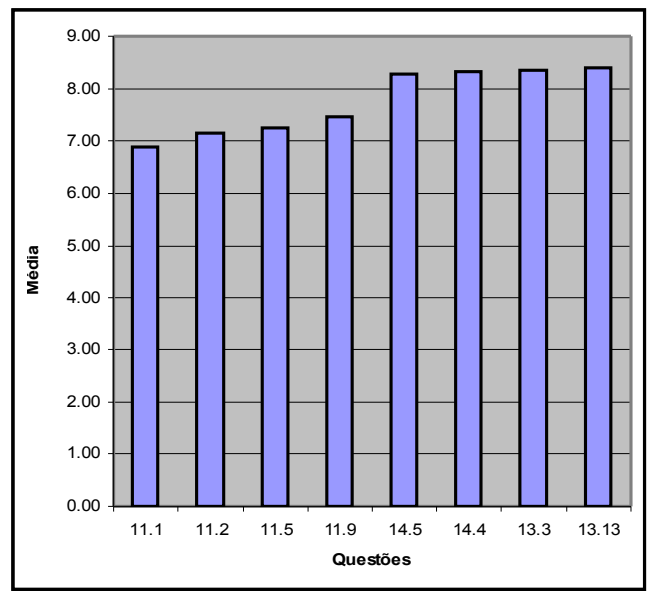

Gráfico 4 - Maiores e menores médias obtidas - Infocentros.

Se considerarmos uma análise mais específica envolvendo as três maiores e menores médias atribuídas por classe de prazer podemos considerar:

Para os prazeres do Meio Digital:

\begin{tabular}{|l|l|l|}
\hline Médias & Questão & Notas \\
\hline Maiores & $\begin{array}{l}\text { 11.10) A possibilidade de jogar com outras pessoas via } \\
\text { Internet/computadores em rede. }\end{array}$ & $(8.2)$ \\
11.14) Poder jogar com gente de qualquer parte do mundo \\
pela Internet. \\
$\begin{array}{l}\text { 11.13) Cenários de vários lugares ao redor do mundo por onde } \\
\text { podemos passar durante o jogo. }\end{array}$ & $(8.0)$ \\
\hline $\begin{array}{l}\text { Menores } \\
\text { 11.1) Imagens, sons e textos aparecendo ao mesmo tempo } \\
\text { durante o jogo. }\end{array}$ & $\begin{array}{l}\text { 11.5) Quando os personagens e objetos de um jogo (plantas, } \\
\text { animais, água, nuvens etc) tem vida própria e se mexem } \\
\text { sozinhos, sem precisar que você clique em nada. } \\
\text { 11.2) Imagens, sons e textos onde os respondentes achem } \\
\text { emocionantes durante o jogo. }\end{array}$ & (7.2) \\
\hline
\end{tabular}

Quadro 3 - Maiores e menores médias atribuídas para a categoria de prazer Meio Digital- Infocentros.

Para os prazeres inerentes a categoria de Imersão:

\begin{tabular}{|l|l|c|}
\hline Médias & Questão & Notas \\
\hline Maiores & $\begin{array}{l}\text { 12.4) Assumir o papel de um personagem do jogo mostrado na } \\
\text { tela do computador, como se você fosse o próprio sujeito. Por } \\
\text { exemplo, no jogo Counter-Strike. }\end{array}$ & \\
\hline
\end{tabular}




\begin{tabular}{|l|l|l|} 
& $\begin{array}{l}\text { 12.8) A possibilidade de ter algum tipo de troca on-line com } \\
\text { outros participantes dos jogos. Por exemplo, compartilhar } \\
\text { informações importantes para a evolução do jogo. }\end{array}$ & $(8.0)$ \\
& $\begin{array}{l}\text { 12.3) Experimentar na tela do computador imagens e sons de } \\
\text { qualidade que dão a impressão de estar no mundo real. }\end{array}$ & $(8.2)$ \\
\hline Menores & $\begin{array}{l}\text { 12.1) Jogar num lugar virtual onde podemos usar nossa } \\
\text { imaginação e viver nossas fantasias. } \\
\text { 12.2) Sensação de ser transportado para um lugar virtual onde } \\
\text { desejamos estar. } \\
\begin{array}{l}\text { 12.6) Possibilidade de não revelarmos nossa verdadeira } \\
\text { identidade quando jogamos pela Intenet. }\end{array}\end{array}$ & $(7.5)$ \\
\hline
\end{tabular}

Para os prazeres inerentes a categoria de Agenciamento:

\begin{tabular}{|l|l|l|}
\hline Médias & Questão & Notas \\
\hline Maiores & $\begin{array}{l}\text { 13.13) Vencer um obstáculo. } \\
\text { 13.3) A qualidade dos efeitos especiais (explosões, tiros, } \\
\text { chutes ao gol etc) dando realismo a suas ações no jogo. } \\
\text { 13.14) Sobreviver a uma derrota inevitável. }\end{array}$ & $(8.3)$ \\
\hline Menores & $\begin{array}{l}\text { 13.19) Construir e manter situações de poder e controle sobre } \\
\text { outros personagens. Por exemplo, ser o prefeito ou uma } \\
\text { autoridade num jogo em uma cidade. } \\
\text { 13.17) Dar vida a objetos imaginários. } \\
\text { 13.7) Poder aplicar o raciocínio do mundo real no mundo } \\
\text { virtual para resolução de quebra-cabeça. }\end{array}$ & $(8.2)$ \\
\hline
\end{tabular}

Quadro 5 - Maiores e menores médias atribuídas para a categoria de prazer Agenciamento - Infocentros.

Para os prazeres inerentes a categoria de Transformação:

\begin{tabular}{|l|l|l|}
\hline Médias & Questão & Notas \\
\hline Maiores & $\begin{array}{l}\text { 14.4) Poder adquirir novas habilidades como o aprendizado de } \\
\text { línguas, tomada de decisões, simuladores de vôos etc. }\end{array}$ & (8.3) \\
$\begin{array}{l}\text { 14.5) Aprender formas de estar no mundo, por exemplo, como } \\
\text { resolver conflitos, como ter sucesso na busca por um } \\
\text { emprego, como educar bem os filhos, como ser melhor pai ou } \\
\text { como se relacionar melhor com os amigos. }\end{array}$ & (8.3) \\
$\begin{array}{l}\text { 14.3) Sentir a experiência do jogo como se fosse uma } \\
\text { experiência pessoal. Por exemplo, podemos sentir o prazer da }\end{array}$ & (8.2) \\
\hline
\end{tabular}




\begin{tabular}{|l|l|l|}
\hline Menores & $\begin{array}{l}\text { vitória do personagem como conquista pessoal. } \\
\text { 14.1) Interferir na história do jogo ao invés de simplesmente } \\
\text { acompanhá-la. }\end{array}$ & (7.5) \\
$\begin{array}{l}\text { 14.10) Poder anular a morte. Por exemplo, o nosso } \\
\text { personagem morre numa determinada fase do jogo e nós } \\
\text { reiniciamos o mesmo jogo em uma fase anterior. }\end{array}$ & (7.7) \\
$\begin{array}{l}\text { 14.7) Estar sempre à procura por informações secretas e } \\
\text { recompensas difíceis de serem conseguidas. }\end{array}$ & (7.9) \\
\hline
\end{tabular}

Quadro 6 - Maiores e menores médias atribuídas para a categoria de prazer Transformação - Infocentros.

$\mathrm{Na}$ comparação geral das respostas apresentadas entre pessoas do sexo feminino e masculino, as pessoas do sexo feminino se aproximam mais das pessoas do sexo masculino com relação aos prazeres de atualização dos jogos. Também são estimuladas de forma parecida pelo prazer de poder experimentar cenários ao redor do mundo através do jogo (questões 11.8 e 11.13). Denominando homens para sexo masculino e mulheres para sexo feminino, podemos observar que homens e mulheres se distanciam quanto aos prazeres relacionados às qualidades multimídicas e periféricos oferecidos pelo computador. As mulheres são mais estimuladas (questão 11.7) nas questões relacionadas à portabilidade dos jogos e os homens (questão 11.4) quando à qualidade dos periféricos interativos (joystik, padstik, teclado, etc).

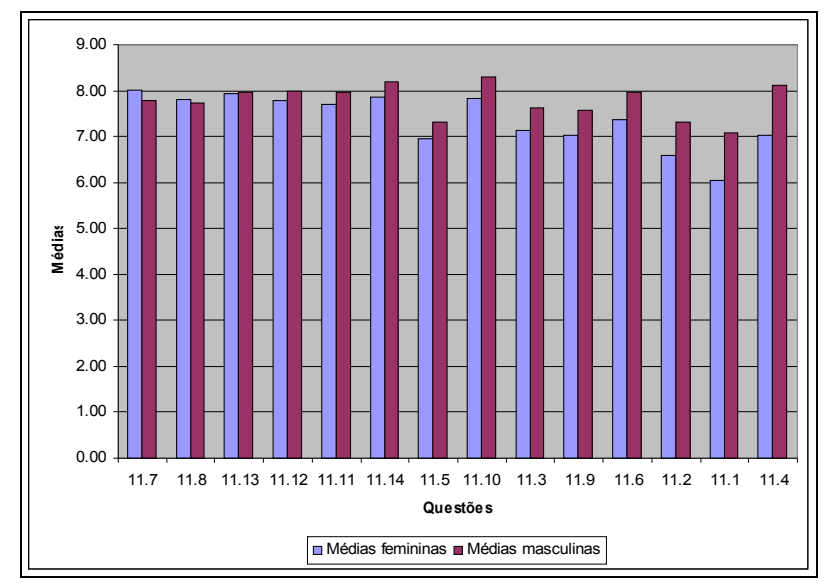

Gráfico 5 - Comparação das médias atribuídas por respondentes do sexo feminino e masculino para a classe de prazer Meio Digital- Infocentro.

Quanto aos prazeres de Imersão, homens e mulheres se aproximam onde se pode usar a imaginação e realizar suas fantasias (questão 12.1). A possibilidade de não se revelar a identidade quando se joga pela Internet é outro fator de aproximação entre homens e mulheres (questão 12.6). Neste item, as mulheres se sentem mais estimuladas em 
comparação com os homens no que diz respeito ao fato de se sentirem transportadas para um lugar onde desejam estar (questão 12.2). Já os homens, quanto ao fato de manterem a sua integridade no mundo real quando estão jogando (questão 12.7).

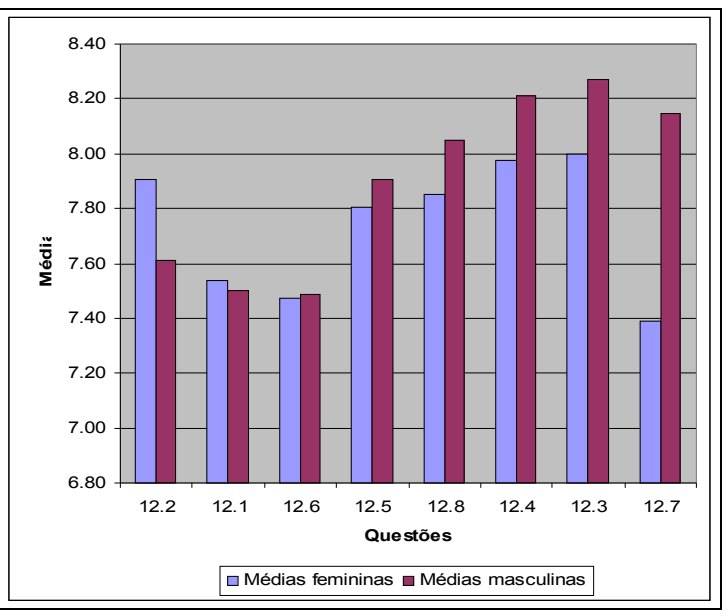

Gráfico 6 - Comparação das médias atribuídas por respondentes do sexo feminino e masculino para a classe de prazer Imersão - Infocentro.

Quanto aos desejos de Agenciamento, mulheres e homens se mostraram parecidos quanto às questões relativas à possibilidade de escolha e decisão permitidas pelos jogos (questão 13.1), e quanto a se viver uma experiência no jogo parecida com o dia a dia descobrindo um enigma ou uma lógica (questão 13.8). Aqui as mulheres foram mais estimuladas quanto as questões relacionadas a se sobreviverem a uma derrota inevitável (questão 13.14), e os homens quanto ao fato de poder sentir que a história do jogo está evoluindo (questão 13.5).

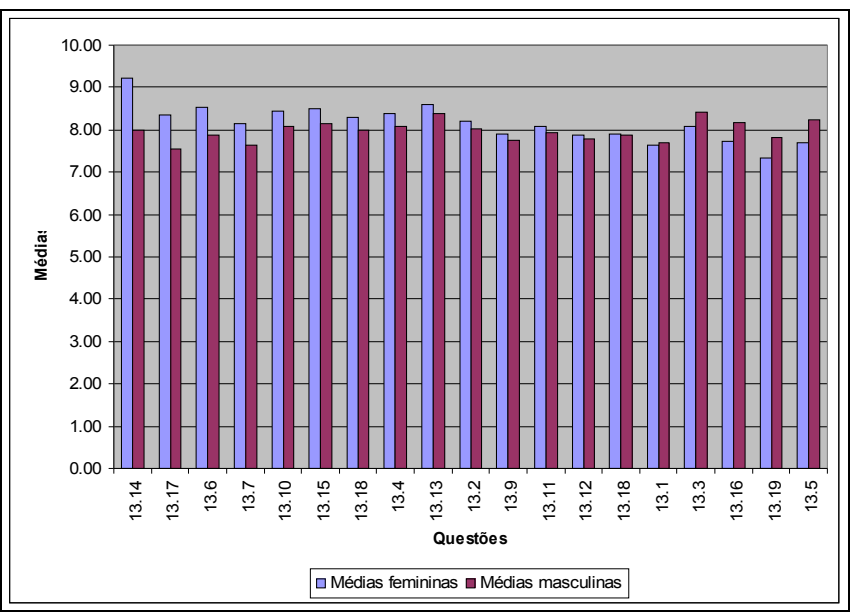

Gráfico 7 - Comparação das médias atribuídas por respondentes do sexo feminino e masculino para a classe de prazer Agenciamento - Infocentro.

Em Transformação, verificamos que homens e mulheres se aproximam quanto às questões de poder experimentar uma situação de jogo de diversas formas diferentes 
(questão 14.2), e quanto à possibilidade de vivenciar a experiência do jogo como uma experiência pessoal (questão 14.3). Nos pontos em que se distanciam, as mulheres se sentem mais estimuladas quanto ao fato de experimentar várias situações de erros até encontrar uma solução satisfatória na história do jogo (questão 14.9), e os homens quanto ao poder de interferir na história do jogo ao invés de simplesmente acompanhá-las.

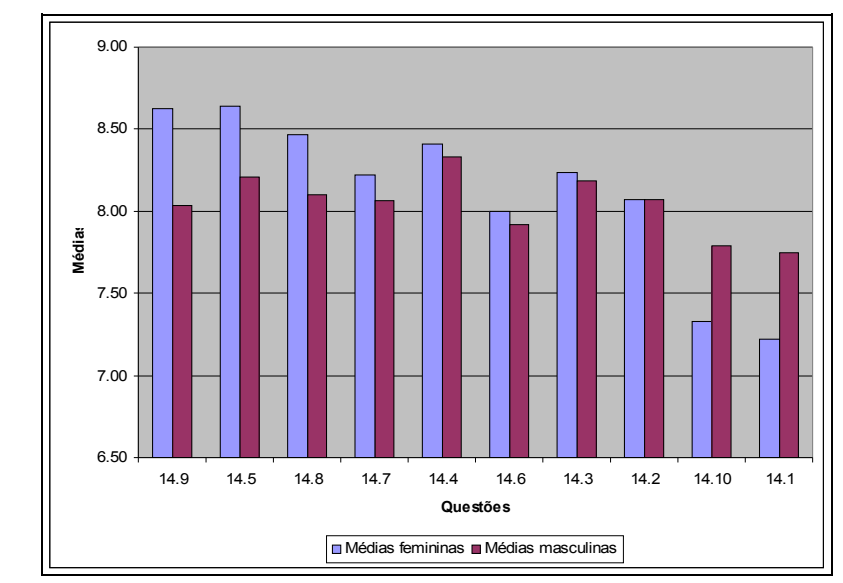

Gráfico 8 - Comparação das médias atribuídas por respondentes do sexo feminino e masculino para a classe de prazer Transformação - Infocentro.

Quando analisamos como a escolaridade se relaciona com as categorias de prazeres examinadas podemos observar que as classes educacionais mais representativas na população dos respondentes, são do ensino fundamental ( $5^{\mathrm{a}}$ e $8^{\mathrm{a}}$ série) e do ensino médio, compondo $89 \%$ do total dos respondentes. Observamos aqui uma diferença pequena nas médias que estas categorias atribuíram para os tipos de prazeres.

Para os prazeres relacionados ao Meio Digital, alunos do ensino fundamental se aproximam mais dos alunos do ensino médio quanto às questões relativas à possibilidade de atualização dos jogos (questão 11.8), e quanto às possibilidades de vivenciar a história do jogo através de cenários ao redor do mundo (questão 11.13). Os alunos do ensino fundamental são estimuladas mais com as questões de portabilidade do meio onde se joga (questão 11.7), e os alunos do ensino médio com a possibilidade de se poder jogar com pessoas de qualquer parte do mundo pela Internet (questão 11.14). 


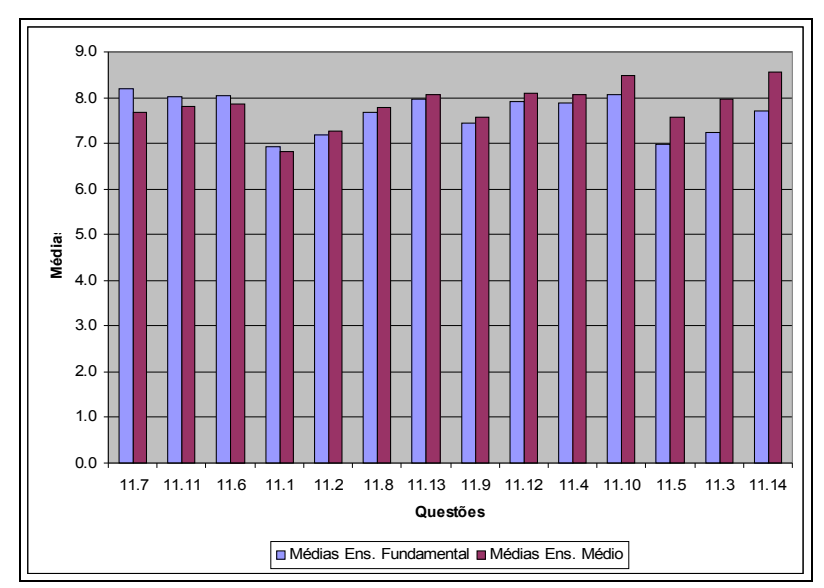

Gráfico 9 - Comparação das médias atribuídas por respondentes do ens.

Fundamental e ens. médio para a classe de prazer Meio Digital - Infocentro.

Nos prazeres de Imersão estes alunos se aproximam mais quanto às médias atribuídas para as questões relativas à utilização da imaginação e experimentação de fantasias em lugares virtuais (questão 12.1), e quanto à possibilidade de poderem realizar algum tipo de troca on-line com outros jogadores. Neste contexto os alunos do ensino fundamental parecem são mais estimulados com as possibilidades de assumirem o papel de uma personagem no jogo, podendo acompanhar a sua evolução como se estivessem olhando para ele (questão 12.5). Já os alunos do ensino médio, são melhores estimulados pela sensação de serem transportados para um lugar virtual onde desejam estar (questão 12.2).

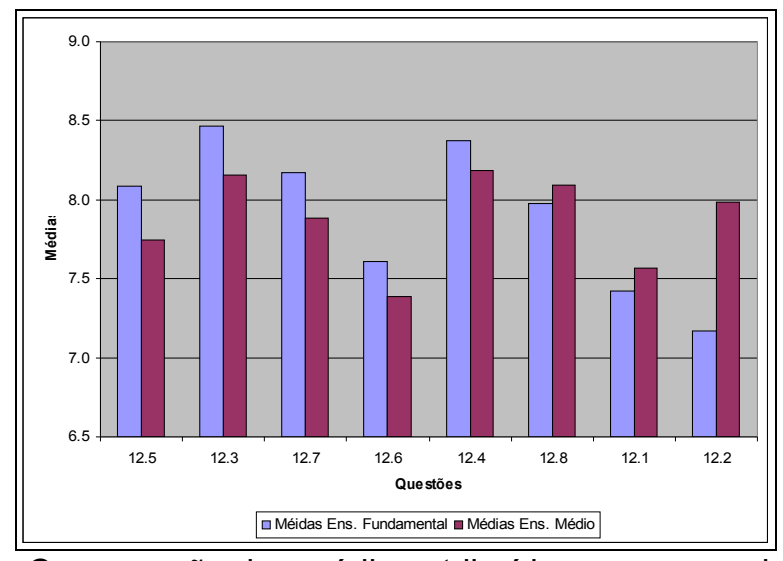

Gráfico 10 - Comparação das médias atribuídas por respondentes do ens.

Fundamental e ens. médio para a classe de prazer Imersão - Infocentro.

Nos prazeres de Agenciamento nos jogos, os alunos parecem ser igualmente estimulados para as questões relacionadas às possibilidades de dominarem uma situação complicada (questão 13.16), e enfatizar ou simular alguns limites (questão 13.18). Os alunos do ensino fundamental são melhores estimulados pela qualidade dos efeitos especiais utilizados nos jogos (questão 13.3), e os alunos do ensino médio quando agenciam na possibilidade de aplicar o raciocínio do mundo real no mundo virtual como se estivessem solucionando um quebra-cabeça (questão 13.7). 


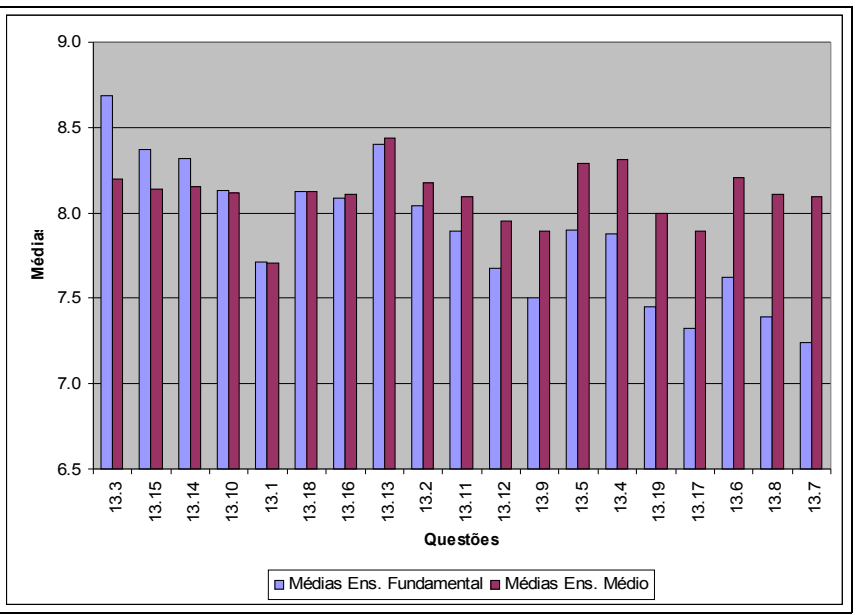

Gráfico 11 - Comparação das médias atribuídas por respondentes do ens.

Fundamental e ens. médio para a classe de prazer Agenciamento - Infocentro.

Em Transformação, os alunos são igualmente estimulados para as questões relativas a poder aprender novas habilidades através do jogo (questão 14.4). Os alunos do ensino fundamental são melhores estimulados em comparação aos alunos do ensino médio nesta classe de prazeres quanto à possibilidade de anulação da morte, presente nos jogos (questão 14.10). Já os alunos do ensino médio são mais estimulados no que diz respeito à possibilidade de interferir na história do jogo, ao invés de simplesmente acompanhá-la (questão 14.1).

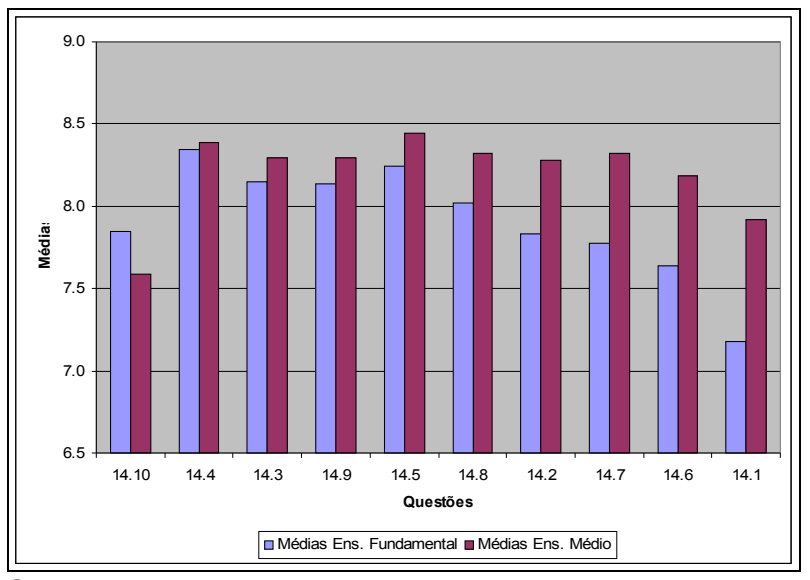

Gráfico 12 - Comparação das médias atribuídas por respondentes do ens.

Fundamental e ens. médio para a classe de prazer Transformação - Infocentro.

A característica ocupacional mais relevante no universo pesquisado se refere aos usuários que estudam e não trabalham. Neste contexto, os prazeres referentes ao Meio Digital apresentaram a maior média atribuída à possibilidade de se jogar com outras pessoas via Internet ou computadores em rede (questão 11.10). A menor média foi atribuída à questão de personagens e objetos de um jogo terem vida distinta e agirem por conta própria no jogo (questão 11.5). 


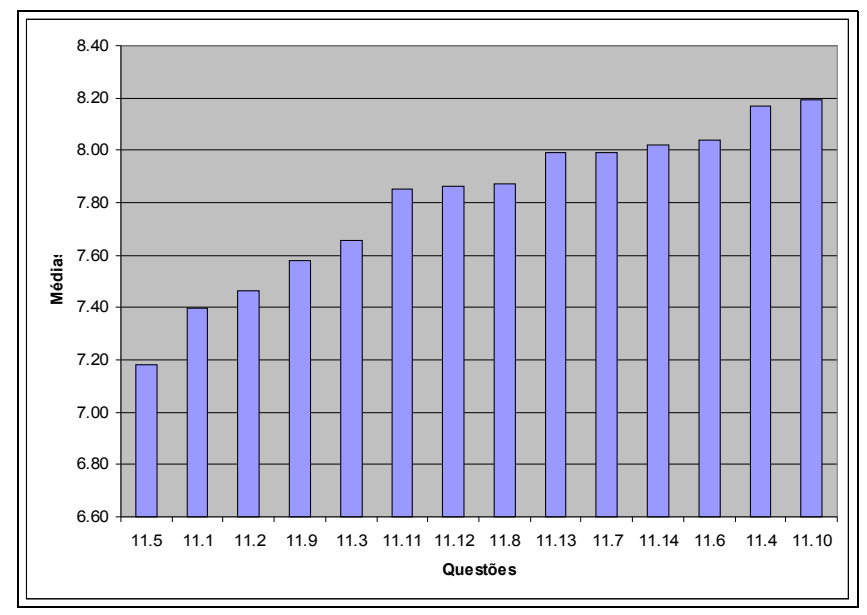

Gráfico 13 - médias atribuídas por respondentes que estudam e não trabalham para a categoria de prazer Meio Digital- Infocentro.

Para os prazeres de Imersão, estes respondentes atribuíram a maior média para a possibilidade de experimentarem na tela do computador imagens e sons de qualidade que dão a impressão de estar no mundo real (questão 12.3). A menor média nesta classe foi atribuída à questão de jogar num lugar virtual onde podemos usar nossa imaginação e viver nossas fantasias (questão 12.1).

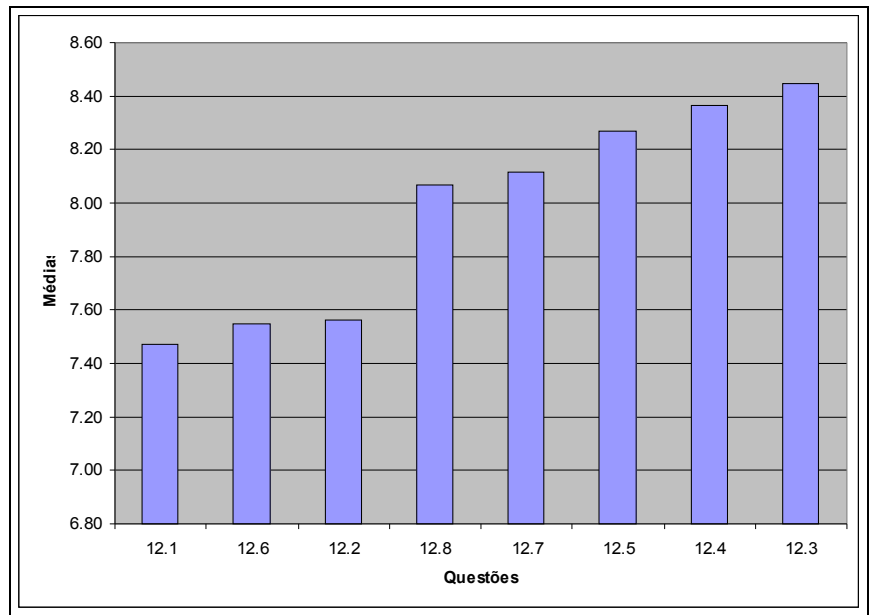

Gráfico 14 - médias atribuídas por respondentes que estudam e não trabalham para a categoria de prazer Imersão - Infocentro.

Nas questões de Agenciamento foi atribuída a maior média para a qualidade dos efeitos especiais dando realismo ao jogo (questão 13.3). As menores médias foram para a possibilidade de vivenciar experiências no jogo parecidas com a do dia-a-dia (questão 13.9). 


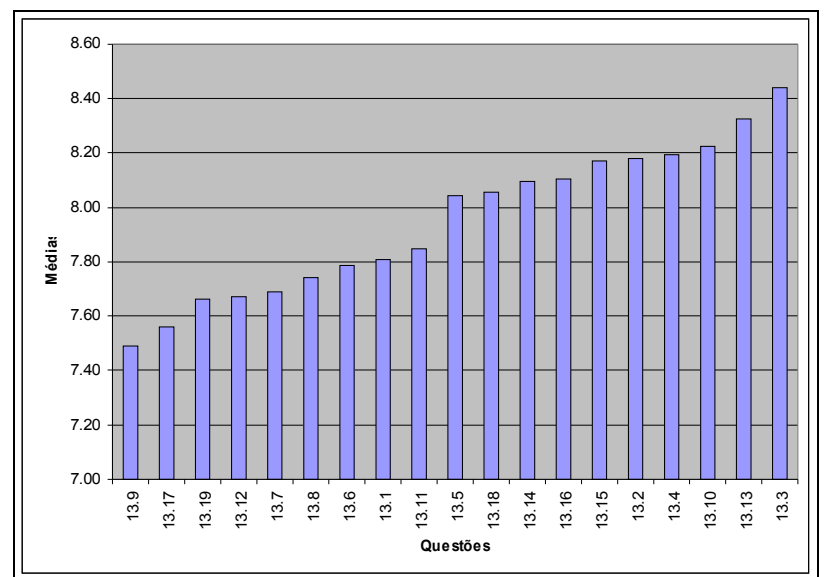

Gráfico 15 - médias atribuídas por respondentes que estudam e não trabalham para a categoria de prazer Agenciamento - Infocentro.

Na categoria de Transformação, estes respondentes atribuíram a maior média para a possibilidade de sentir a experiência do jogo como se fosse uma experiência pessoal (questão 14.3). A melhor média nesta classe foi atribuída à possibilidade de atuar na história do jogo ao invés de simplesmente acompanhá-la (questão 14.1).

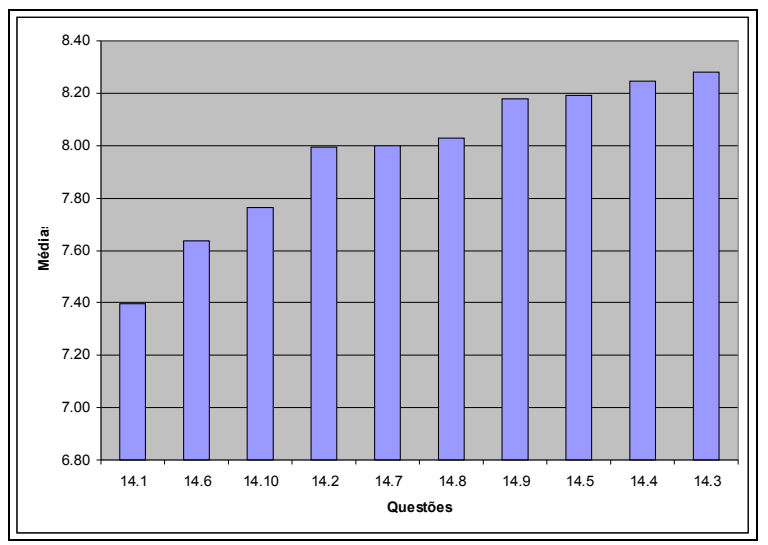

Gráfico 16 - médias atribuídas por respondentes que estudam e não trabalham para a categoria de prazer Transformação - Infocentro.

Quando analisamos as maiores e menores notas obtidas nas respostas por categorias de prazeres podemos observar que as questão relacionada ao Meio Digital que mais recebeu nota inferior a $4(10 \%)$ foi a questão referente à portabilidade, ou seja, poder de transportar e jogar em um computador diferente (questão 11.3). A questão nesta categoria que mais recebeu notas superiores a $7(63 \%)$ foi a questão relacionada à possibilidade de jogar com outras pessoas via Internet ou em computadores em rede (questão 11.10). 


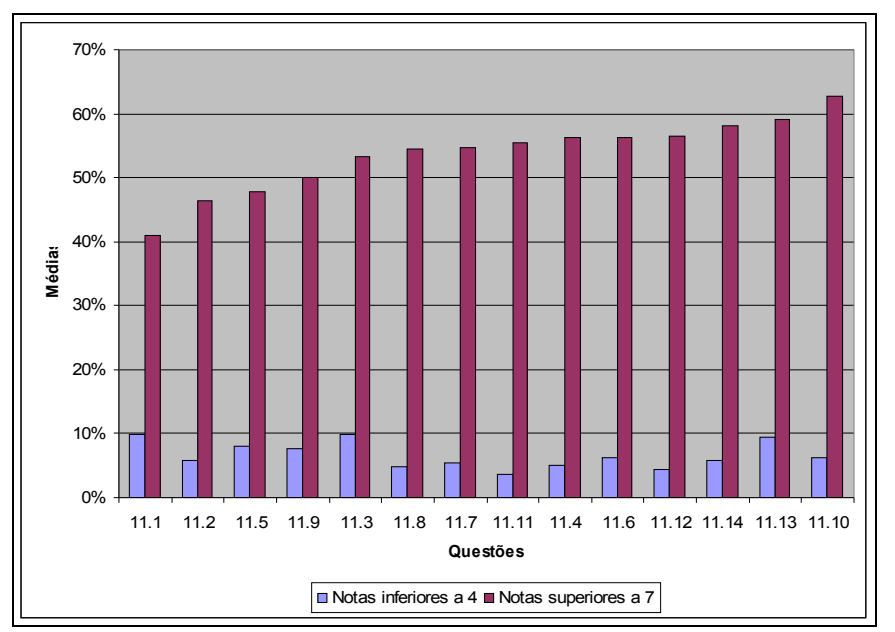

Gráfico 17 - notas inferiores a 4 e superiores a 7 atribuídas à classe de prazer Meio Digital - Infocentro.

Na categoria de Imersão a questão que mais recebeu notas inferiores a $4(9 \%)$ se refere à possibilidade de não revelarmos nossa verdadeira identidade quando jogamos pela Internet (questão 12.6) e a questão que mais recebeu notas superiores a 7 (61\%) foi a de experimentar na tela do computador imagens e sons de qualidade que dão a impressão de estar no mundo real (questão 12.3).

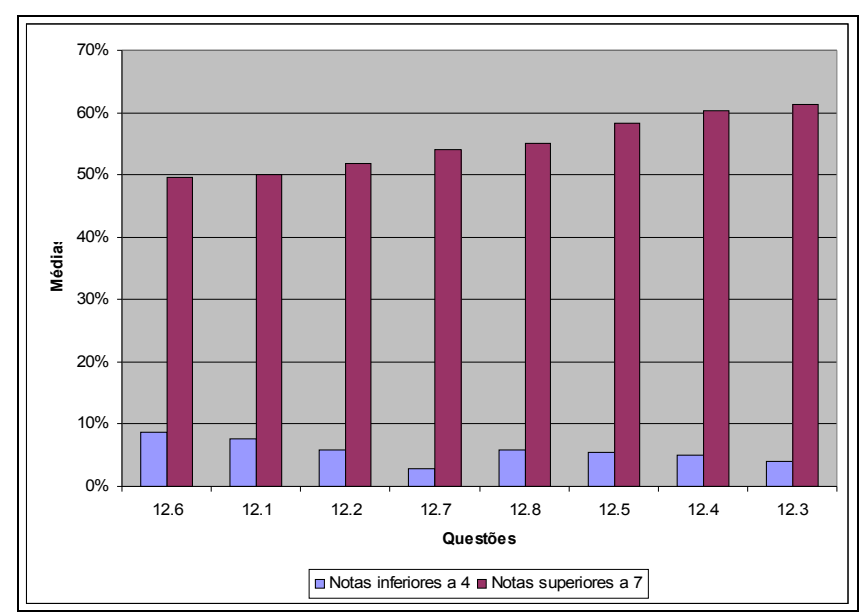

Gráfico 18 - notas inferiores a 4 e superiores a 7 atribuídas à classe de prazer Imersão - Infocentro.

Para Agenciamento, o maior número de notas inferiores a $4(6 \%)$ foi para a questão referente à possibilidade de viver uma experiência parecida com a do dia-a-dia descobrindo um enigma ou uma lógica (questão 13.8). A questão que mais recebeu notas superiores a 7 (66\%) foi aquela sobre vencermos um obstáculo no jogo (questão 13.13). 


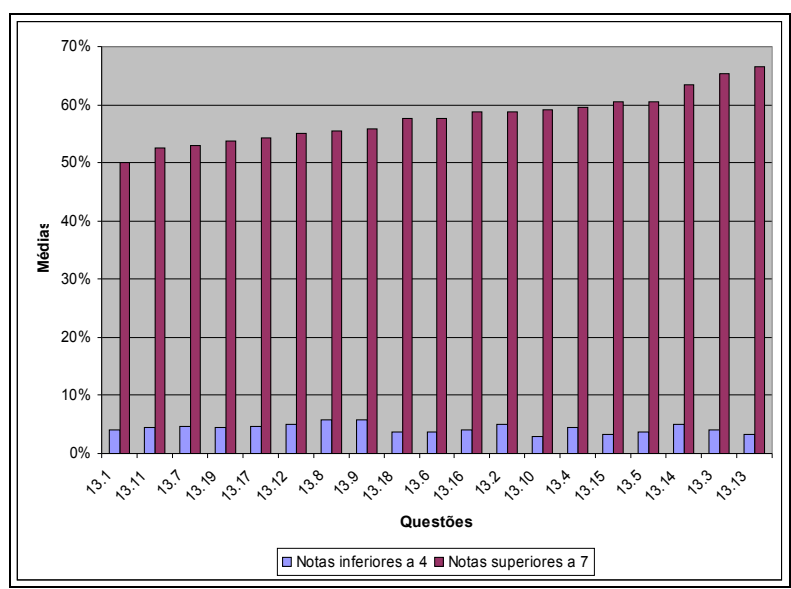

Gráfico 19 - notas inferiores a 4 e superiores a 7 atribuídas à classe de prazer Agenciamento - Infocentro.

Na categoria Transformação a questão que mais recebeu notas inferiores a 4 foi referente a poder compreender melhor através da experiência dos jogos temas polêmicos e injustiças sociais (8\%) (questão 14.6). A questão com o maior número de notas superiores a $7(63 \%)$ se refere a como podemos vivenciar a experiência do jogo como se tivéssemos encenando a história (questão 14.3).

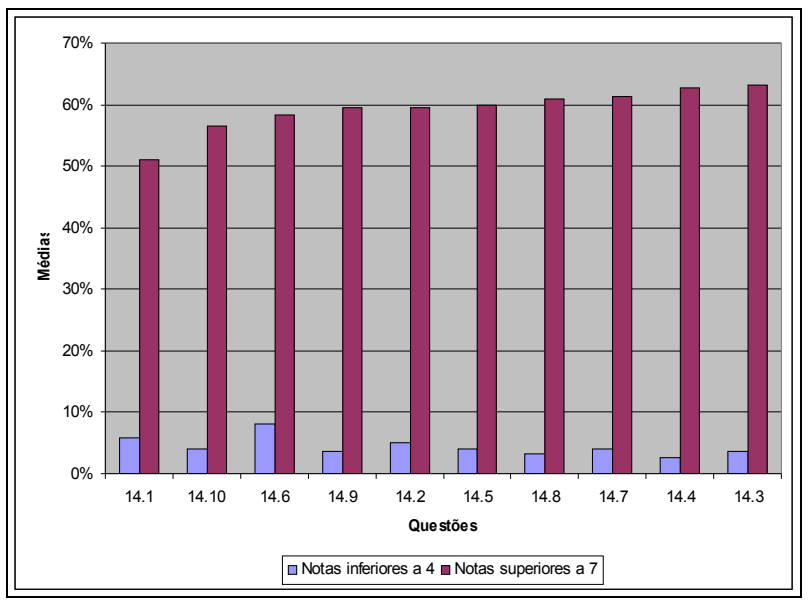

Gráfico 20 - notas inferiores a 4 e superiores a 7 atribuídas à classe de prazer Transformação - Infocentro.

Para facilitar a análise das respostas obtidas através das questões qualitativas 15 e 16 do questionário, consideramos a possibilidade de agrupá-las em função de possíveis similaridades através de palavras e expressões contidas em cada resposta e que pudessem atribuir alguma tônica em seu sentido. Neste agrupamento procuramos gerar tópicos que representassem grupos, mesmo que composto por apenas uma resposta isolada, de opiniões concretas dos respondentes.

Foram desconsideradas de nosso universo de análise as respostas obtidas sem algum sentido no contexto das questões e as respostas em branco. A partir deste critério, para a 
questão 15 foram descartadas 165 respostas e para a questão 16 desconsideramos 147. O quadro a seguir apresenta as palavras que denominamos de 'expressões dominantes' e consideramos como representativas no universo das questões obtidas:

\begin{tabular}{|c|c|c|}
\hline & \multicolumn{2}{|c|}{ PERGUNTAS } \\
\hline & 15 & 16 \\
\hline $\begin{array}{c}\text { PALAVRAS- } \\
\text { CHAVE }\end{array}$ & $\begin{array}{l}\text { aprender a perder } \\
\text { aprender e desenvolver } \\
\text { coisas impossíveis } \\
\text { dependente } \\
\text { dia a dia } \\
\text { diferenciados, educacionais e criativos } \\
\text { envolver } \\
\text { estar no jogo } \\
\text { eu inventei } \\
\text { experimentar } \\
\text { felicidade } \\
\text { formador de opinião } \\
\text { intercâmbio } \\
\text { liberdade } \\
\text { mais realista } \\
\text { não exitir na net } \\
\text { personagens } \\
\text { raciocinar } \\
\text { raciocínio, inteligencia e paciência } \\
\text { rede nacional } \\
\text { sentir emoção } \\
\text { vida real }\end{array}$ & $\begin{array}{l}\text { acessíveis } \\
\text { comunicação } \\
\text { diverte, ensina } \\
\text { emprego } \\
\text { idéias são inovadoras } \\
\text { infocentro } \\
\text { Infocentro } \\
\text { jogo da vida } \\
\text { jogos mais realisticos } \\
\text { lazer } \\
\text { liverassem } \\
\text { menos violentos e mais educativos } \\
\text { novos jogos } \\
\text { pesquisa muito boa } \\
\text { piadas } \\
\text { proibir } \\
\text { rapidez no raciocício, emocionante } \\
\text { reais } \\
\text { RPG } \\
\text { saindo da rua } \\
\text { vicia } \\
\text { viciam }\end{array}$ \\
\hline
\end{tabular}

Quadro 7 - Palavras relevantes extraídas das respostas referentes às perguntas 15 e 16 - infocentro.

Seguindo o nosso critério de análise, e considerando as palavras relevantes conforme quadro apresentado, pudemos construir tópicos como respostas mais significativas.

Em relação à questão 15 (“Agora, gostaríamos que você comentasse qualquer outro aspecto não mencionado no questionário que você julga como sendo um fator importante também"):

- A experiência do jogo é algo segregado das experiências cotidianas reais;

- Os jogos podem estimular o raciocínio rápido e a capacidade de pensar de quem joga;

- Através dos jogos pode-se adquirir coordenação motora;

- Os jogos podem gerar dependência e ficar muito tempo jogando pode ser prejudicial ao indivíduo;

- Os atributos de som, gráficos e movimentos realistas deixam os jogos muito mais interessantes.

Em relação à questão 16 ("Este espaço é para que você comente livremente o tema desta pesquisa - Jogos, Prazeres e Narrativas Interativas. Suas experiências, impressões e sugestões são importantes para que possamos conhecer e melhorar nossos serviços."): 
- É importante o serviço prestado pelos Infocentros à comunidade pois permite que os jovens saiam das ruas, e venham acessar atividades nos computadores como jogar e acessar a Internet;

- É importante que se tenham mais jogos educativos e menos jogos violentos;

- A pesquisa ajuda a saber como os jogos são importantes;

- Os jogos por computadores são apenas mais uma forma de lazer. Ficar muito tempo em frente ao computador pode ser prejudicial.

\section{Primeiras Considerações}

Como conclusões preliminares do comportamento da população de usuários de jogos, podemos dizer que jogar nos Infocentros é uma prática dominada por pessoas de etnia branca e parda do sexo masculino e com idade entre 15 e 18 anos. Os respondentes em sua maioria estudam, mas não trabalham, e freqüentam os Infocentros da zona Sul e Leste da Capital de São Paulo, o que nos permite afastar a possível relação entre a questão "não estudar" como um fator de estímulo para a prática de jogos eletrônicos.

Quanto ao comportamento dos indivíduos em relação às classes de prazeres pelos jogos podemos concluir que a maioria dos respondentes apresentou boas médias em relação à escala de estímulos de 0 a 10 ao se referirem no questionário do prazer que sentem quando estão jogando. As médias neste sentido nunca ficaram a baixo de 6.9 (questão 11.1) onde podemos concluir que, por mais superficial que possamos ter sido na tentativa de mensurar o quanto e onde estes jogadores são estimulados, podemos crer que os jogos representam instrumentos potencializadores de estímulos prazerosos em usuários que experimentam suas narrativas interativas.

Sobre um ponto de vista geral das médias atribuídas para as categorias de prazeres apresentadas, as questões com maiores médias são aquelas referentes às categorias de Agenciamento e Transformação, e as menores às categorias de Imersão e ao Meio Digital. Sendo assim, estes jogadores quando jogam, apresentam uma tendência a se envolverem mais com as possibilidades de interferirem nas narrativas dos jogos e com possibilidades onde sentem que estão encenando uma experiência real que produza algum efeito transformador em suas vidas. As características do Meio Digital como os atributos relativos às imagens interativas, sons e dispositivos de interação e a sensação 
de estar imerso em um ambiente virtual ficaram em segundo plano.

Analisando as três maiores e menores médias por categoria de prazer, podemos concluir que às maiores médias associadas ao Meio Digital estão relacionadas à coletividade e as redes. Este é um fator interessante quando confrontado com as características sociais e econômicas da população respondente. Se pudermos elaborar alguma conclusão prévia neste sentido, a população de baixa renda e possivelmente carente de inclusão digital, diante da possibilidade de experimentar jogos eletrônicos, parece valorizar aspectos referentes à comunicação e ao compartilhamento destas experiências com outros jogadores.

Para as menores médias atribuídas nesta classe de prazeres, os aspectos da multimídia dos computadores e as possibilidades de interatividade endógena (onde os elementos internos do jogo interagem entre si) no jogo não parecem estimular muito estes usuários. Devemos ressaltar no entanto que a população pesquisada, conforme já mencionamos no início deste capítulo, utiliza jogos acessados pela Internet através dos computadores dos Infocentros. Considerando que estes computadores não são preparados especificamente para a prática de jogos, é possível que este resultado tenha sofrido algum tipo de interferência quanto ao tipo de resposta obtida. Considerando a hipótese onde estes respondentes pudessem, através de computadores mais adequados, experimentar jogos com melhor qualidade e resolução de imagens, sons e textos, suas opiniões poderiam ter variado significativamente.

As questões mais pontuadas quanto a Imersão estão em torno do aspecto relacionado ao jogador poder compartilhar algo com alguém através do jogo e com o fato de poder experimentar o jogo atuando em primeira pessoa. Atributos de imagem, som e textos interativos tomam força neste contexto quando parecem auxiliar no grau de realismo da experiência vivida. Observamos neste ponto um fator potencializador de estímulos prazerosos relacionados a questões da coletividade. Estes aspectos podem representar um indício na valorização de questões relacionadas à formação de comunidades em torno dos jogos, como forma de melhor envolver seus jogadores. Neste contexto, as questões de vivenciar desejos e fantasias parecem não estimular muito estes jogadores. Quanto à possibilidade de jogar pela Internet, o fator preservação da identidade do jogador também não parece muito interessante. Com isto podemos concluir que estes jogadores não estão 
preocupados com o seu próprio grau de exposição ao jogarem, ou então, não se dão conta do grau de exposição a que estão sujeitos quando jogam em rede. Estes parecem mais envolvidos pela possibilidade de serem identificados e reconhecidos por seus feitos quando jogam.

O Agenciamento parece influenciar fortemente os aspectos que favorecem o realismo da experiência vivida no jogo, onde podemos estabelecer vínculos entre a narrativa experimentada e nossa vida real. Outro fator de forte influência nesta categoria de prazer parece ser referente as possibilidades apresentadas aos jogadores no sentido de superar derrotas inevitáveis durante os jogos. Nos jogos eletrônicos, normalmente podemos retomar uma narrativa a partir de um ponto já experimentado, e tentar interferir de forma diferente como se recriássemos a narrativa com o objetivo de não incorrermos em erros que não gostaríamos de ter cometido. Este aspecto parece abrir uma discussão sobre como e quanto realmente poderíamos aprender com as experiências dos jogos e, nesse sentido, evitarmos erros em nossas vidas reais.

Atuar no jogo com um ponto de vista centralizador onde podemos exercer algum tipo de poder parece não estimular muito os jogadores. As possibilidades de controle associadas ao Agenciamento durante o jogo parece ter maior efeito quando se faz de forma mais sutil.

A correlação entre o que pode se aplicar do mundo real ao mundo dos jogos também não parece muito envolvente para os jogadores. Por exemplo, observamos que aspectos da vida real não ajudam muito jogadores a resolverem enigmas apresentados pelo jogo. Aqui os jogadores esperam contar com a possibilidade de abstração e fantasia do jogo com relação ao mundo real para descobrirem novas formas de lidar com os mesmos problemas conforme tentamos identificar através da questão 13.7.

Adquirir novas habilidades e resolver conflitos estabelecendo uma ponte entre o universo virtual e real é o prazer mais pontuado para a classe Transformação. Este aspecto, relacionado com a possibilidade da experimentar o jogo como uma experiência pessoal são os aspectos que mais estimulam os jogadores. Neste ponto, os jogadores parecem não apenas querer vivenciar sensações prazerosas mas também exprimirem sua vontade pela exploração de conhecimentos e habilidades nos jogos. 
De forma geral, a sensação de estar participando da história de um jogo ao invés de apenas assisti-la parece não causar muito efeito sobre estes jogadores. O que parece ser contraditório aos aspectos mencionados no item anterior. Estes jogadores parecem não perceber que através das possibilidades interativas dos jogos, sejam narradas em primeiro ou em terceira pessoa, acabam participando efetivamente da construção da narrativa. Ao longo da narrativa dos jogos, o prazer pela negação ou interrupção da própria narrativa, definitivamente parece ser algo que não estimula muito estes jogadores. Se existe prazer nos jogos relacionados a experimentar situações similares as experimentadas na vida real, questões polêmicas e sociais não parecem ser um fator muito expressivo no universo de usuários tratado na pesquisa.

Quando comparamos as respostas entre pessoas do sexo feminino e masculino vimos que as mulheres se aproximam mais dos homens, no aspecto de se sentirem envolvidos nos jogos com relação aos seus prazeres de atualização, e quanto à possibilidade de poder experimentar cenários diferentes ao redor do mundo, ou seja, fator referente à renovação do conteúdo e continuidade na experimentação de narrativas interativas com cenários variados. Outro fator de aproximação deste grupo está na possibilidade de pessoas de ambos os sexos poderem utilizar a imaginação e realizar fantasias durante as possibilidades de escolhas e decisões permitidas pelo jogo. Ambos parecem estimulados quanto às questões de não revelarem suas identidades durante o jogo, e poderem experimentar situações de formas diferentes como se fosse uma experiência pessoal.

Os homens se distanciam mais das mulheres quando estimulados nos prazeres de Transformação relacionados às qualidades multimídicas e periféricos oferecidos pelo computador, onde parecem se interessar pela qualidade e versatilidade dos periféricos interativos como joystick, padstick e teclado. Homens também parecem ser mais estimulados pela sensação envolvendo a possibilidade de, independente da evolução na narrativa, manterem sua integridade no mundo real conforme a história do jogo evolui, podendo interferir na narrativa ao invés de simplesmente acompanhá-las.

As mulheres neste caso parecem ser mais estimuladas para as questões relacionadas à portabilidade que permitam transportar a experiência dos jogos para outros meios e locais físicos. Poder sobreviver a uma derrota inevitável e experimentar várias situações de erros até encontrar uma solução satisfatória na história do jogo também são prazeres que 
parecem estimular mais as mulheres que os homens nos jogos.

Quando analisamos os prazeres pelos jogos levando em consideração as questões de escolaridade de seus jogadores podemos concluir que, para a classe de alunos com maior representatividade entre os jogadores que são os alunos do ensino fundamental e médio conforme apontam os resultados da pesquisa, observamos que os fatores aos quais estes mais se aproximam em termos de estímulos estão nas questões relativas à possibilidade de atualização dos jogos. Vivenciar a história do jogo através de cenários ao redor do mundo, utilizar nossa imaginação e poder experimentar nossas fantasias também são fatores de aproximação entre esta classe de respondentes. Outros fatores ainda de aproximação estão relacionados à possibilidade de dominarem uma situação complicada e simularem alguns limites. Quanto aos prazeres Transformadores, os estímulos se aproximam às questões onde podem aprender novas habilidades através do jogo.

Ao analisarmos como as categorias de prazeres podem afetar os respondentes da pesquisa considerando a situação ocupacional mais relevante, ou seja, jogadores que estudam mas não trabalham, concluimos que estes respondentes atribuíram as maiores médias referentes aos prazeres do Meio Digital para a questão relacionada à possibilidade de se jogar com outras pessoas via Internet ou computadores em rede. Para as questões relacionadas à Imersão as maiores médias foram evidenciadas para a possibilidade de experimentar na tela do computador imagens e sons de qualidade que dão a impressão de estar no mundo real. Para Agenciamento, as maiores médias ficaram com os prazeres relativos à qualidade dos efeitos especiais dando realismo ao jogo. Com relação aos prazeres de Transformação, as maiores médias ficaram com a possibilidade de sentir a experiência do jogo como se fosse uma experiência pessoal.

O maior número de respondentes da pesquisa atribuiu notas superiores a 7, o que indica que são, para a maioria das questões, bem estimulados pelos prazeres dos jogos de computadores. Neste contexto, se analisarmos as categorias de prazeres que mais receberam notas superiores a 7 e menos notas inferiores a 4, encontramos os prazeres de Agenciamento, e quando procuramos pelas categorias que menos receberam notas superiores a 7 e mais notas inferiores a 4 encontramos os prazeres de Imersão. Sendo assim podemos concluir que sob o ponto de vista do número de notas atribuídas também 
é bem provável que os prazeres de Agenciamento sejam aqueles que mais estimulam os respondentes e os prazeres de Imersão aqueles que menos os estimulam.

Através da classificação das respostas qualitativas atribuídas pelos respondentes concluímos que, para a questão referente a outros aspectos não considerados em nosso questionário, os respondentes reconhecem que os jogos ajudam no aprimoramento de habilidades mentais como raciocínio e coordenação motora, porém eles representam algo bem distinto de nossas experiências na vida real. Apesar destes respondentes considerarem os jogos uma prática interessante, temem que os prazeres pelos jogos possam implicar em dependências. Como ponto de reforço às nossas conclusões podemos ressaltar que, dentre as palavras relevantes extraídas nestas respostas, identificamos ênfase maior para: aprender, raciocinar, dia-a-dia, vida real, mais realista, sentir emoção, dependente e vicia.

Os respondentes evidenciaram em seus comentários a importância dos serviços prestados pelos Infocentros à comunidade no sentido de permitir que, através dos jogos, seus usuários possuam uma atividade fora das ruas. Através de considerações a respeito da importância de jogos educativos, os respondentes apontam a conciliação de atividades lúdicas e educacionais executadas nos Infocentros. Os termos utilizados pelos respondentes que reforçam estas conclusões são: Infocentro, saindo da rua, diverte e ensina. 


\section{ALGUMAS CONCLUSÕES}

A utilização de meios digitais, envolvendo as possibilidades interativas apresentadas pelo computador, dispositivos de hardware, interfaces homem-máquina e principalmente o potencial de síntese no desenvolvimento de programas computacionais e algoritmos, pode representar um rico campo de experimentação, expressão e pesquisa para seus criadores e usuários.

Quando tentamos interpretar os agentes estéticos colocados pelos meios digitais através de recursos computacionais, obtemos formas sistêmicas para simulação da vida num contexto virtual onde se torna possível a abertura de canais para acesso a certas emoções, pensamentos e condutas.

Para Murray (2003, p.176) os princípios estéticos das narrativas digitais interativas, mais do que prazeres usuais, são prazeres que antecipamos conforme nossos desejos são despertados pela emergência dos novos meios digitais.

Quando passamos a entender melhor como os jogos podem envolver e influenciar seus usuários, concluímos que sua exploração no sentido de vivenciarmos certas emoções percorre um caminho através de possibilidades complexas e imprevisíveis.

Através dos resultados que chegamos em nossa pesquisa, principalmente no âmbito da pesquisa realizada nos Infocentros de São Paulo, fica evidente que os jogos eletrônicos podem oferecer padrões expansivos de experimentação através de seus princípios estéticos, conforme questionamento lançado por nós na INTRODUÇÃO. Não há dúvida que o universo dos jogos possua atributos envolventes no sentido de estimular seus usuários, seja de forma positiva ou não, através de uma experiência intensa. É importante ressaltarmos que, com o resultado da pesquisa prática, deparamos com uma gama complexa de dados, não permitindo que chegássemos a conclusões imediatas para as médias obtidas nas comparações específicas da população daquela comunidade. Porém, sob um ponto de vista mais genérico, podemos concluir que os respondentes da pesquisa se mostraram bastante estimulados e envolvidos pelos aspectos aqui considerados como 
prazeres específicos dos jogos eletrônicos. O maior número de respondentes atribuí notas superiores a 7, quando apresentada numa escala de 0 a 10 para a forma como se sentem estimulados por estes prazeres quando jogam.

Acreditamos que para conclusões mais específicas, levando em consideração as características próprias dos Infocentros, análises mais amplas seriam necessárias. Apesar de considerarmos que atingimos nosso objetivo quanto à proposta inicial na construção de um primeiro entendimento geral sobre como os prazeres nos jogos envolvem os usuários dos Infocentros, temos consciência de que estes resultados estão direcionados para a realidade de um universo particular. Entendemos que para um estudo prático mais aprofundado e amplo sobre o complexo universo dos jogos, seriam necessários investimentos que envolvessem o refinamento da metodologia já iniciada nesta pesquisa considerando o desenvolvimento de instrumentos de análises mais precisos. Atrelados ao aprimoramento da metodologia, outros recursos se fazem necessários para o sucesso de futuras pesquisas sobre o tema dentre os quais podemos citar: sala teste, software e computadores dedicados para acompanhamento dos usuários e da pesquisa, desenvolvimento de jogos específicos para a análise de situações particulares e o envolvimento de profissionais com qualificações no universo de análises estatísticas e nas novas linguagens digitais. Tais aprimoramentos seriam importantes no sentindo de amplificarmos nossa escala de sensibilidade para uma análise mais depurada sobre os subgrupos decorrentes das amostragens elaboradas.

Através das respostas apresentadas pelos os usuários dos Infocentros, notamos que estes percebem e reconhecem como os prazeres nos jogos proporcionam, através de sua prática, experiências onde podem vivenciar suas fantasias em um universo ficcional intensificadas pelas características participativas e imersivas, e pela experiência de serem transportados para um ambiente simulado. Estes usuários comentam que se sentem bastante envolvidos pela possibilidade de explorar e agenciar possíveis conteúdos do mundo real representado na forma de narrativas eletrônicas, onde se mantém preservada a idéia de recursividade e recriação das narrativas desempenhadas nos jogos. Comentam ainda, que um dos aspectos mais envolventes e estimulantes nos jogos está relacionado à capacidade gratificante de realizar ações significativas e ver os resultados de suas decisões e escolhas. Aspecto este que consideramos ao longo da pesquisa como os prazeres de Agenciamento. Considerando que esta comunidade é 
em maioria representada por população de baixa renda e possivelmente carente quanto aos recursos de tecnologia que possam incluí-los de forma mais ampla no contexto digital, quando diante da possibilidade de experimentar jogos eletrônicos, valorizaram aspectos referentes à comunicação e ao compartilhamento destas experiências com outros jogadores. Este é um aspecto bastante interessante considerando que os jogos, através de suas características participativas, tendem a estimular seus usuários através da prática em ambientes multiusuários, com a formação de comunidades virtuais em torno de seu tema narrativo conforme abordamos no segundo capítulo "JOGOS ELETRÔNICOS".

O fato dos jogos serem colaborativos e participativos, permitindo a seus usuários o compartilhamento de suas experiências no ciberespaço, proporciona uma boa oportunidade para que, através dos jogos, seja exercitada a construção de uma sociedade global mais inteligente e democrática. "Que venham os designers de games nos trazerem os brinquedos que nos libertem dos medos que se cristalizaram em egoísmo e egocentrismos!" (LEÃO, 2005).

Porém, não temos como distinguir até que ponto a busca deste usuário pelos prazeres implícitos nas narrativas dos jogos é fruto de uma escolha consciente em torno de suas necessidades mais preeminentes e justificáveis. Usuários podem dedicar várias horas diárias na prática dos jogos dependendo de quanto se sentem envolvidos pelas narrativas.

É importante refletirmos sobre as possíveis conseqüências de nos entregarmos de forma inconseqüente aos prazeres que nos conduzirão pelas narrativas interativas dos jogos. Não é difícil perceber que estas possibilidades podem ser exploradas através da elaboração de jogos com tendências diretamente voltadas para nossos desejos e fantasias.

Em um mundo tão diverso, podemos facilmente nos deparar com situações onde possibilidades abertas pelas mídias digitais, mais especificamente no contexto dos jogos eletrônicos e sua relevância, são exploradas no sentido de conduzir seu desenvolvimento para fins que justifique interesses específicos, guiados por poderes que giram certos motores de nossa sociedade com fatores econômicos, políticos, religiosos e militares. $\mathrm{Na}$ história das novas mídias, os jogos eletrônicos foram os que se desenvolveram de forma 
mais rápida (SANTAELLA, 2004). Não seria menos importante tentar imaginar quais as implicações futuras que tal emergência ainda nos aguarda. Os nossos hábitos potencializados pelo desenvolvimento de outras mídias digitais massivas como a Internet, o cinema interativo e a televisão digital que carregam em sua essência paradigmas similares aos dos jogos eletrônicos, podem ainda esperar grandes surpresas sob o ponto de vista de mudanças no contexto social e cultural.

Quando olhamos para a evolução dos jogos eletrônicos atuais, notamos o surgimento de certas tendências impostas pela sua indústria. Tendências que buscam evidenciar a construção de mundos virtuais, personagens e objetos cada vez mais primorosos e realistas tomam força no sentido de apreender cada vez mais usuários através da intensificação de prazeres explícitos em gráficos, sons e movimentos "emocionantes". Um fenômeno diferente ocorre quanto à evolução de novos gêneros e temas narrativos. Versões mais populares de jogos atualmente tendem a repetição de gêneros que já fizeram sucesso com o público voltando sempre para um contexto mais lúdico e cercado de ação e aventuras. Este aspecto abre um importante tema para reflexão sobre o uso de jogos através de possibilidades cada vez mais potencializadas de Imersão, Agenciamento e Transformação.

Parece bastante natural que sob tais circunstâncias, o trabalho de arte digital jogue um olhar crítico e questionador sobre os jogos eletrônicos tentando explorar seus paradigmas em contextos diferentes aos atuais na tentativa de tornar explícito ou apenas discutível aquilo que não percebemos através dos padrões estéticos impostos pela indústria de jogos.

A exemplo de trabalhos artísticos já discutidos, abre-se aqui um possível caminho para a gamearte no sentido de explorar os prazeres como forma de questionar a produção comercial dos jogos e a refletir sobre como estes podem nos envolver através de suas narrativas, conduzindo talvez os usuários mais atentos por uma viagem mais proveitosa. Acreditamos que algumas respostas que conseguimos através desta pesquisa, possam servir como ponto de partida para novos projetos poéticos que venham a explorar questões relacionadas à estética interdisciplinar dos jogos eletrônicos construídos no sentido de envolver seus usuários além das possibilidades lúdicas. É interessante notar que, diferente de jogos mais comuns, este tipo de exploração pode não possuir um 
objetivo definido na sua concepção, subvertendo de início este paradigma básico dos jogos eletrônicos.

Até que ponto podemos esperar que o poder sedutor dos jogos nos conduzam para experiências focadas na satisfação de prazeres que se fecham em seu caráter lúdico? Muito distante hoje de suas origens mais remotas, os jogos eletrônicos podem transcender limites delineados em seu caráter lúdico para novas possibilidades engendradas em sua própria estética. Mesmo que a realização de nossos prazeres e fantasias através dos jogos não ajude a lidar com situações reais, poderia ao menos oferecer um treinamento seguro e experiências construtivas em áreas que possuem um valor prático. Neste sentido, artistas, cientistas e filósofos poderiam, através dos jogos, tentar abrir novas possibilidade para discussões e experimentação em áreas ainda pouco desbravadas pelo conhecimento. 


\section{REFERÊNCAS BIBLIOGRÁFICAS}

ALMONT, Jacques. A Imagem. Campinas: Papirus Editora, 1993.

ASCOTT, Roy. "Photography at the Interface." Electronic Culture: Technology and Visual Representation. Ed. Timothy Druckrey. New York: Aperture, 1996.

. Turning on Technology. Disponível em : <http://www.cooper.edu/art/techno/ essays/ascott.html>. Acesso em dez. de 2003.

BAUDRILLARD, Jean. Cultura y Simulacro. Barcelona: Kairós, 1987.

BETHKE, Erik. Game development and production. Los Rios Boulevard, Texas. 2003.

CAMPBELL, Jeremy. Grammatical Man. New York: Simon\&Schuster, 1982.

COUCHOT, Edmond. A segunda interatividade. Em direção a novas práticas artísticas, in: DOMINGUES, Diana (org.). A arte no século XXI: Tecnologia, ciência e criatividade. São Paulo: Ed. UNESP, 2003. p. 27-38.

COUCHOT, Edmond. Da representação à Simulação: Evolução das Técnicas e das Artes da Figuração, in: PARENTE, André (org.). Imagem-máquina: a era das tecnologias do virtual. Rio de Janeiro: Editora 34, 1993, p. 37-48.

DELEUZE, Gilles. Cinema 1: a Imagem-Movimento. São Paulo: Brasiliense, 1985. . Cinema 2: A Imagem-Tempo. São Paulo: Brasiliense, 1985.

DELEUZE, Gilles e GUATTARI, Felix. O Anti-Édipo: Capitalismo e Esquizofrenia. Lisboa: Assírio e Alvim s/d, 1972.

FOLEY, James D. Computer Graphics, Principles and Practice. 2.ed. in C. Massachusetts: Addison-Wesley, 1997. 
LAURENTIZ, Sílvia. Imagens Animadas, Tese de Doutorado, COS-PUC/SP.1999.

. Processos computacionais evolutivos na Arte. Ars - Revista do Departamento de Artes Plásticas ECA/USP - Vol.1, n.2 (2. semestre). São Paulo:Editora 34, 2003. p. 4555 .

. Sobre "O design da narrativa como simulação imersiva" de Renata Correia Lima Ferreira Gomes. Relato Crítico - Encontro da Compôs 2005 / GT Criação e poéticas digitais (manuscrito).

LEÃO, Lucia. Cultura de jogos, gamearte e os exercícios da webmatilha. 2005. Disponível em: < http://www.sescsp.org.br/sesc/hotsites/game_cultura/texto_lucialeao.doc>. Acesso em: 12 dez. 2006.

LUCERNA JUNIOR, Alberto. Arte da Animação. São Paulo: Senac, 2002.

MACHADO, Arlindo. Máquina e Imaginário: O Desafio das Poéticas Tecnológicas. São Paulo: EDUSP,1993.

. Regimes de Imersão e Modos de Agenciamento, in: MEDEIROS, Maria Beatriz de (org.). Arte Pesquisa. Brasília: Unb, ANPAP, 2003. p. 173-181.

MITCHELL, W. J. T. The Reconfigured Eye: visual truth in the post-photographic era. Massachusetts: MIT, 1992.

MOLES, Abraham. Arte e Computador. Lisboa: Afrontamento, 1991.

MURRAY, Janet H. Hamlet no Holodeck: o futuro da narrativa no ciberespaço. São Paulo: Itaú Cultural- Unesp. 2003.

PARENTE, André. Imagem-máquina: a era das tecnologias do virtual. Rio de Janeiro: Editora 34, 1993.

PAUL, Christiane. Digital Art. London: Thames \& Hudson, 2003.

PLAZA, Júlio. A imagem digital. Tese (Livre-docência em Artes Plásticas) - Faculdade de Comunicações e Artes, Universidade de São Paulo, São Paulo.1991. 
. Arte e interatividade: autor-obra-recepção. 2000. Disponível em: < www.cap.eca. usp.br/ars2/arteeinteratividade.pdf >. Acesso em: 01 fev. 2007.

PLAZA, Julio e TAVARES, Mônica. Processos Criativos com Meios Eletrônicos: Poéticas Digitais. São Paulo: Editora Hucitec, 1998.

PRADO, Gilberto. Desertesejo: um projeto de ambiente virtual multiusuário na Web. 2000. Disponnível em: <http://www.cap.eca.usp.br/wawrwt/ ambvirtuais.html>. Acesso em: 23 out. 2005.

PRADO, Gilberto e LAURENTIZ, Silvia. Uma Leitura Poética de Ambientes Virtuais Multiusuário. Ars - Revista do Departamento de Artes Plásticas ECA/USP - Vol. 1, n.3 (1. semestre). São Paulo: Editora 34, 2004. p. 23-34.

POPPER, Frank. Art of the Electronic Age. London: Thames \& Hudson, 1997.

QUEAU, PHILLIPE. O Tempo Virtual, in: PARENTE, André (org.). Imagem-máquina: a era das tecnologias do virtual, Rio de Janeiro: Editora 34, 1993.

RUSH, Michael. New Media in Late 20th Century. London: Thames and Hudson, 1999.

SANTAELlA, Lucia. Imagem - Coignição, Semiótica, Mídia. São Paulo: Editora lluminuras, 2001. . Games e Comunidades Virtuais. 2004. Disponível em: <http://www. canalcontemporaneo.art.br/tecnopoliticas/archives/000334.html>. Acesso em: $12 \mathrm{dez}$. 2006.

SILVA, Adriana de Souza. Arte, Interfaces e gráficas e espaços virtuais. Ars - Revista do Departamento de Artes Plástica da ECA/USP - n.4. São Paulo, 2004. p. 80-86.

WILSON, Stephen. Informaton arts: intersections of art, science, and technology. Cambridge: MIT Press (Leonardo), 2002. 
ANEXOS 


\section{ANEXO 1. FONTES ADICIONAIS DE CONSULTA}

A seguir apresentamos o quadro sinóptico contendo fontes adicionais de consulta utilizada no tema pesquisado:

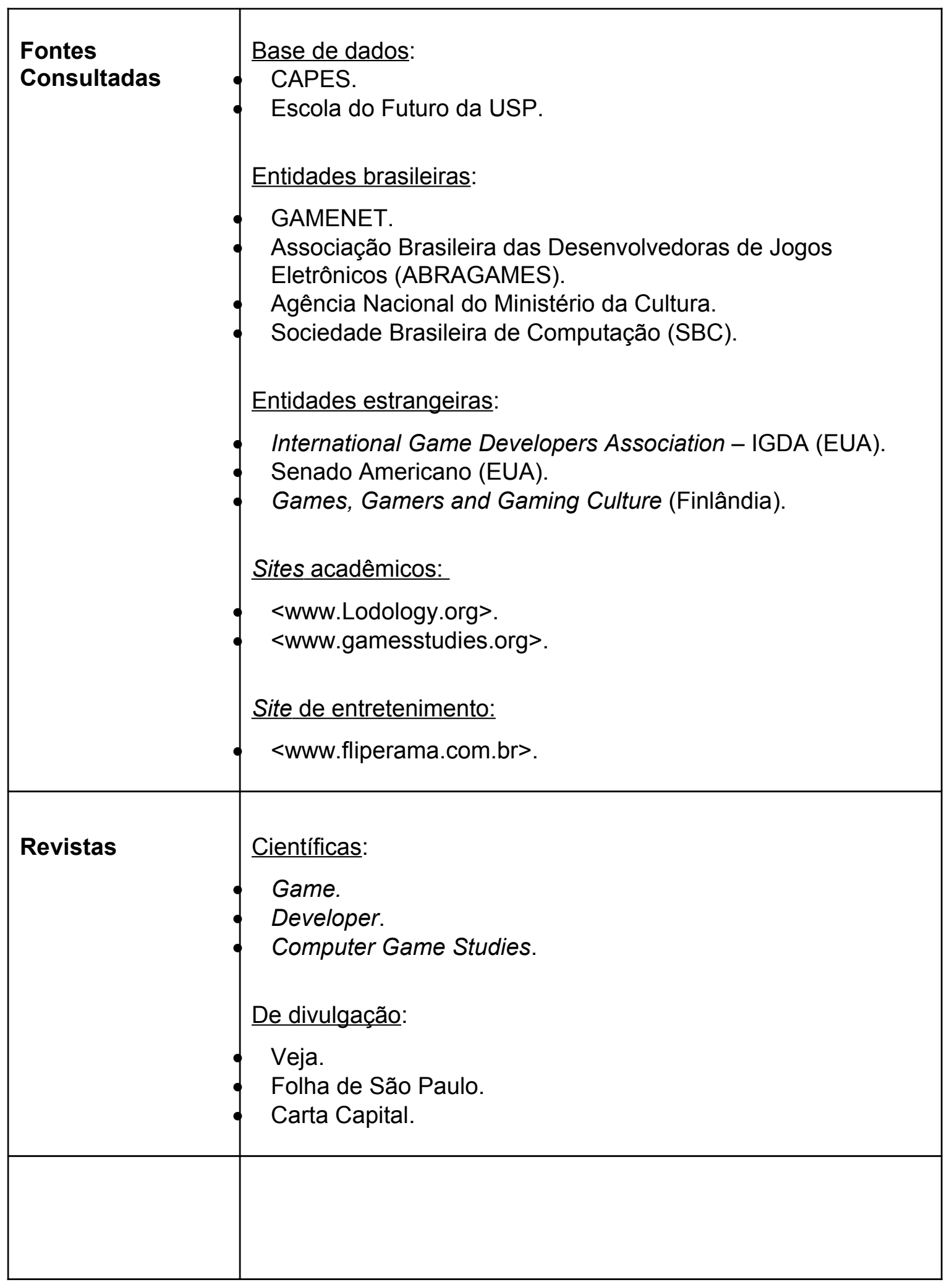




\begin{tabular}{|c|c|}
\hline $\begin{array}{l}\text { Temas } \\
\text { Identificados } \\
\text { (Teses) }\end{array}$ & $\begin{array}{l}\text { Educação: } \\
\text { "As emoções no processo de aprendizagem". } \\
\text { "Desejo e saber". } \\
\text { "Novas cartografias cognitivas: uma análise do uso das } \\
\text { tecnologias intelectuais por crianças da rede pública em } \\
\text { Salvador". } \\
\text { "Pitfallf and promises - using internet for education in a third } \\
\text { world environment". } \\
\text { Comunicação: } \\
\text { "As reinvenções do lúdico". } \\
\text { "Condições técnicas e fruição da imagem digital". } \\
\text { "Matéria digital". } \\
\text { "Narrativa e eficácia: estereótipo na cultura contemporânea". } \\
\text { "Quem conta um conto aumenta um ponto... Um estudo sobre } \\
\text { o design no audiovisual interativo". } \\
\text { "Signos visuais como mediadores tecnológicos em ambientes } \\
\text { educacionais virtuais". } \\
\text { Psicologia: } \\
\text { "Cartografia da sala de aula: O aprendizado transformador". } \\
\text { "Despertar de um desejo". } \\
\text { "Estratégias do desejo em pessoa". } \\
\text { "O usiano de metáforas na computação". } \\
\text { "Técnicas básicas para geração de imagens em jogos } \\
\text { Ambientados em labirintos". } \\
\text { Sociologia: }\end{array}$ \\
\hline $\begin{array}{l}\text { Centos } \\
\text { Universitários } \\
\text { Nacionais com } \\
\text { Competências em } \\
\text { Jogos Eletrônicos }\end{array}$ & $\begin{array}{l}\text { Universidade Federal do Rio de Janeiro - UFRJ - Rio de } \\
\text { Janeiro - RJ. } \\
\text { Universidade Federal do Rio Grande do Sul - CEI-UFRGS - } \\
\text { Porto Alegre - RS. } \\
\text { PUC Rio -ICADGames - Rio de Janeiro - RJ. } \\
\text { Universidade Federal do Pernambuco - UFPE - Recife - PE. } \\
\text { Unisinos - São Leopoldo - RS. } \\
\text { Centro Univ. Metodista - UniBennett.- Rio de Janeiro - RJ. } \\
\text { Centro Universitário Positivo - Unicenp - Paraná - PR. } \\
\text { Univ. Anhembi Morumbi - São Paulo - SP. } \\
\text { Laboratório de Tecnologias Interativas - Interlab - /POLI/USP } \\
\text { - São Paulo - SP. }\end{array}$ \\
\hline
\end{tabular}




\begin{tabular}{|c|c|}
\hline Congressos & $\begin{array}{l}\text { Nacionais: } \\
\text { Wjogos. } \\
\text { Sibgrapi. } \\
\text { I Workshop Brasileiro de Jogos e Entretenimento digital - } \\
\text { Wjogos. } \\
1^{\text {a. }} \text { Congerência de Desenvolvedores de Games do Estado - } \\
\text { CDG. } \\
\text { Internacionais: } \\
\text { Electronic Game Show - EGS. } \\
\text { World Cyber Games Brasil. } \\
\text { Brasilian Workshop on Games and Digital Entertainment II } \\
\text { Congresso Internacional de Tecnologia e Inovação em Jogos } \\
\text { para Computadores (IN2 Games). } \\
\text { Application and Development of Computer Games - ADCOG. } \\
\text { International Conference on Computers and Games - CG. } \\
\text { International Conference on Entertainment Computing - ICEC. }\end{array}$ \\
\hline
\end{tabular}




\section{ANEXO 2. ATIVIDADES REALIZADAS NA PESQUISA DE CAMPO}

Em linha com a metodologia do projeto foram definidas e cumpridas as seguintes atividades de campo no projeto Conexões Científicas:

- Desenho dos testes:

- Análise da adequação dos procedimentos e metodologia escolhida;

- Desenvolvimento dos questionários;

- Definição dos questionários.

- Fase pré-teste

- Aplicação de entrevistas virtuais como pré-teste;

- Recebimento das entrevistas pré-teste;

- Análise das entrevistas pré-teste;

- Re-elaboração das entrevistas virtuais;

- Definição das entrevistas virtuais.

- Fase de aplicação

- Aplicação das entrevistas virtuais (síncronas e assíncronas);

- Análise e relatório parcial das entrevistas virtuais;

- Discussão do relatório;

- Entrega do relatório parcial das entrevistas;

- Discussão e validação dos primeiros resultados com os entrevistados.

- Elaboração do relatório da pesquisa

- Análise dos resultados do relatório parcial e final;

- Elaboração do relatório final;

- Discussão do relatório com as coordenadoras;

- Entrega do relatório final da pesquisa;

- Elaboração de artigos;

- Entrega de artigos. 


\section{Cronograma da pesquisa de campo}

\begin{tabular}{|l|r|r|}
\hline \multicolumn{1}{|c|}{ Cronograma do Projeto } & \multicolumn{1}{c|}{ Iníco } & \multicolumn{1}{c|}{ Término } \\
\cline { 2 - 3 } & $\mathbf{9 / 1 / 2 0 0 4}$ & $\mathbf{4 / 3 0 / 2 0 0 5}$ \\
\hline 1) Fase do Desenho & $\mathbf{9 / 1 / 2 0 0 4}$ & $\mathbf{1 0 / 3 1 / 2 0 0 4}$ \\
\hline Análise da adequação dos procedimentos e metodologia escolhidos & $9 / 1 / 2004$ & $9 / 30 / 2004$ \\
\hline Desenvolvimento dos questionários & $10 / 1 / 2004$ & $10 / 20 / 2004$ \\
\hline Definição dos questionários & $10 / 21 / 2004$ & $10 / 31 / 2004$ \\
\hline 2) Fase Pré teste & $\mathbf{1 1 / 1 / 2 0 0 4}$ & $\mathbf{1 2 / 1 / 2 0 0 5}$ \\
\hline Aplicação de entrevistas virtuais como pré-teste & $11 / 1 / 2004$ & $11 / 5 / 2004$ \\
\hline Recebimento das entrevistas pré-teste & $11 / 8 / 2004$ & $11 / 12 / 2004$ \\
\hline Análise das entrevistas pré-teste & $11 / 16 / 2004$ & $11 / 19 / 2004$ \\
\hline Re-elaboração das entrevistas virtuais & $11 / 22 / 2004$ & $11 / 26 / 2004$ \\
\hline Definição das entrevistas virtuais & $11 / 29 / 2004$ & $12 / 1 / 2004$ \\
\hline 3) Fase da Aplicação & $\mathbf{1 2 / 2 / 2 0 0 4}$ & $\mathbf{1 / 3 1 / 2 0 0 5}$ \\
\hline Aplicação das entrevistas virtuais (síncronas e assíncronas) & $12 / 2 / 2004$ & $12 / 17 / 2004$ \\
\hline Análise e relatório parcial das entrevistas virtuais & $12 / 20 / 2004$ & $1 / 5 / 2005$ \\
\hline Discussão do relatório & $1 / 5 / 2005$ & $1 / 5 / 2005$ \\
\hline Entrega do relatório parcial das entrevistas & $1 / 12 / 2005$ & $1 / 12 / 2005$ \\
\hline Discussão e validação dos primeiros resultados com os entrevistados & $1 / 13 / 2005$ & $1 / 21 / 2005$ \\
\hline 4) Elaboração do Relatório de Pesquisa & $1 / 22 / 2005$ & $4 / 30 / 2005$ \\
\hline Análise dos resultados do relatório parcial e final & $1 / 22 / 2005$ & $2 / 4 / 2005$ \\
\hline Elaboração do relatório final & $2 / 5 / 2005$ & $3 / 4 / 2005$ \\
\hline Discussão do relatório com as coordenadoras & $3 / 7 / 2005$ & $3 / 16 / 2005$ \\
\hline Entrega do relatório final da pesquisa & $3 / 16 / 2005$ & $3 / 31 / 2005$ \\
\hline Elaboração de artigos & $4 / 1 / 2005$ & $4 / 15 / 2005$ \\
\hline Entrega de artigos & $4 / 16 / 2005$ & $4 / 30 / 2005$ \\
\hline
\end{tabular}

\begin{tabular}{|c|c|c|c|c|c|c|}
\hline \multirow{2}{*}{ Cronograma do Projeto } & \multirow{2}{*}{\begin{tabular}{l|r|r|l|l|}
\multicolumn{3}{|c}{ Novembro } \\
1 & 8 & 15 & 22 & 29
\end{tabular}} & \multirow{2}{*}{\begin{tabular}{|l|l|l|l|}
\multicolumn{4}{|c|}{ Dezembro } \\
6 & 13 & 20 & 27 \\
\end{tabular}} & Janeiro & Fevereiro & Março & \multirow{2}{*}{\begin{tabular}{l|l|l|l}
\multicolumn{3}{c}{ Abril } \\
4 & 11 & 18 & 25
\end{tabular}} \\
\hline & & & \begin{tabular}{|l|l|l|l|}
3 & 10 & 17 & 24 \\
\end{tabular} & \begin{tabular}{l|l|l|l|l|}
7 & 7 & 14 & 212 \\
\end{tabular} & \begin{tabular}{|l|l|l|l|}
4 & 14 & 21 & 28 \\
\end{tabular} & \\
\hline & & & & & & \\
\hline 1) Fase do Desenho & & & & & & \\
\hline Anál. Adeq. dos proced & & & 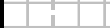 & & & \\
\hline Desenv. dos quest. & & & 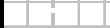 & & & \\
\hline Def. dos quest. & & & - & & & \\
\hline 2) Fase Pré teste & & & $\|$ & & & \\
\hline Confirmar Lan-house & & | & I & & & \\
\hline Confirmar colégio & & & 1 & & & \\
\hline Aplic. de entrev. Virt. pré-teste & & & I & & & \\
\hline Receb. Entrev. pré-teste & & & 1 & & & \\
\hline Anál. Entrev. pré-teste & & & 1 & & & \\
\hline Re-elab. Entrev. virtuais & & & 1 & & & \\
\hline Defin. Entrev. virtuais & & & 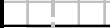 & & & \\
\hline 3) Fase da Aplicação & & & & & & \\
\hline Aplic. das entrev. virtuais & & & . & & & \\
\hline Anál. e relat. parcial das entrev. & & & & & & \\
\hline Disc. do relatório & & & 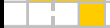 & & & \\
\hline Entrega do relat. Parcial & & & 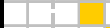 & & & \\
\hline Disc. e valid. dos 1os. Result. & & & - & & & \\
\hline 4) Elab. do Relatório de Pesquisa & & $\|$ & i & & & \\
\hline Anál. Result. do relat. parcial e final & & t & 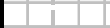 & & & \\
\hline Elab. do relat. final & & 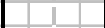 & 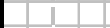 & & & \\
\hline Disc. do relat. com as coordenadoras & & & i & & & \\
\hline Entrega do relatório final da pesquisa & & & 1 & & & \\
\hline Elaboração de artigos & & I & 1 & & & \\
\hline Entrega de artigos & & $\pi$ & 7 & & & \\
\hline
\end{tabular}




\section{ANEXO 3. QUESTIONÁRIO ON-LINE}

Versão integral do questionário on-line aplicado:

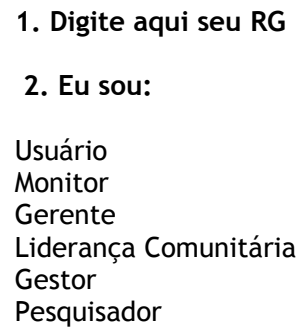

2. Eu sou:

Usuário

Monitor

Gerente

Liderança Comunitária

Gestor

Pesquisador

3. Sexo

Masculino Feminino

4. Ano em que nasceu

5. Cor - Etnia (auto atribuição segundo classificação IBGE)

Branco

Preto

Pardo

Amarelo

Indígena

6. Escolaridade

Analfabeto

Educação Infantil/Pré escola

Ensino Fundamental $1^{\mathrm{a}}$ a $4^{\mathrm{a}}$

Ensino Fundamental $5^{\mathrm{a}}$ a $8^{\mathrm{a}}$

Ensino Médio

Curso Profissionalizante

Ensino Superior

Pós graduação

Supletivo

7. Situação Ocupacional

7.1 Estuda?

Sim

Não

7.2 Trabalha?

Sim

Não

8. Qual é sua renda familiar? - renda familiar é a soma de todos os rendimentos das pessoas que moram com você e pertencem a sua família - pai, mãe, irmãos, marido, mulher, avós, tios e/ou sobrinhos (SM = salário mínimo).

menos de $1 \mathrm{SM}$

mais de $1 S M$ e até $2 S M$

mais de 2 SM e até $4 S M$

mais de 4 SM e até 6 SM

mais de 6 SM e até $8 S M$

mais de 8 SM e até 10 SM

mais de $10 \mathrm{SM}$ 


\section{Quantas pessoas formam a sua família?}

2

4

5

6

7

10

mais de 10

\section{Identificação do Infocentro/Escola/Lan-House}

10.1 Região

São Paulo Capital - Região Norte

São Paulo Capital - Região Sul

São Paulo Capital - Região Leste

São Paulo Capital - Região Oeste

São Paulo Capital - Região Centro

Interior

Litoral

11. Queremos, através deste questionário conhecer o que faz os jogos eletrônicos interessantes e estimulantes para você.

Considere que não há uma resposta certa ou errada. 0 que nos interessa neste questionário é saber o que você pensa e gosta.

Para isso você deverá indicar o quanto cada uma das situações listadas abaixo é interessante, numa escala de 0 a 10 , sendo que 0 representa algo completamente sem interesse e 10 algo muito interessante e prazeroso. Se você não tiver opinião sobre alguma das situações, marque a opção "Não tenho opinião".

Neste primeiro bloco vamos avaliar o que o computador oferece.

Como você se sente durante o jogo com relação a:

11.1 Imagens, sons e textos aparecendo ao mesmo tempo durante o jogo.

$\begin{array}{llllllllllll}0 & 1 & 2 & 3 & 4 & 5 & 6 & 7 & 8 & 9 & 10 & \text { Não tenho opinião }\end{array}$

11.2 Imagens, sons e textos emocionantes.

$\begin{array}{llllllllllll}0 & 1 & 2 & 3 & 4 & 5 & 6 & 7 & 8 & 9 & 10 & \text { Não tenho opinião }\end{array}$

11.3 Possibilidade de utilizar o mesmo jogo em outros computadores.
0
12
4
$\begin{array}{lll}5 & 6 & 7\end{array}$
89
10 Não tenho opinião

11.4 Macetes com o teclado, mouse, joystick, fones de ouvido, e outros dispositivos que podem melhorar o seu desempenho no jogo.

11.5 Quando os personagens e objetos de um jogo (plantas, animais, água, nuvens etc) tem vida própria e se mexem sozinhos, sem precisar que você clique em nada.

$\begin{array}{llllllllllll}0 & 1 & 2 & 3 & 4 & 5 & 6 & 7 & 8 & 9 & 10 & \text { Não tenho opinião }\end{array}$

11.6 A possibilidade de salvar o jogo para continuar jogando depois.

$\begin{array}{llllllllllll}0 & 1 & 2 & 3 & 4 & 5 & 6 & 7 & 8 & 9 & 10 & \text { Não tenho opinião }\end{array}$ 
11.7 A possibilidade de jogar tanto em computadores como em videogames, na televisão, telefones celulares etc...

$\begin{array}{llllllllllll}0 & 1 & 2 & 3 & 4 & 5 & 6 & 7 & 8 & 9 & 10 & \text { Não tenho opinião }\end{array}$

11.8 Possibilidade do jogo ser atualizado e ampliado em outras versões mais avançadas do mesmo jogo.

$\begin{array}{llllllllllll}0 & 1 & 2 & 3 & 4 & 5 & 6 & 7 & 8 & 9 & 10 & \text { Não tenho opinião }\end{array}$

11.9 A possibilidade de jogar individualmente contra o computador.

$\begin{array}{llllllllllll}0 & 1 & 2 & 3 & 4 & 5 & 6 & 7 & 8 & 9 & 10 & \text { Não tenho opinião }\end{array}$

11.10 A possibilidade de jogar com outras pessoas via Internet/computadores em rede.

$\begin{array}{llllllllllll}0 & 1 & 2 & 3 & 4 & 5 & 6 & 7 & 8 & 9 & 10 & \text { Não tenho opinião }\end{array}$

11.11 A possibilidade de escolher jogar individualmente contra o computador e/ou com outras pessoas.

$\begin{array}{llllllllllll}0 & 1 & 2 & 3 & 4 & 5 & 6 & 7 & 8 & 9 & 10 & \text { Não tenho opinião }\end{array}$

11.12 O fato de poder saltar de um lugar para o outro ao redor do mundo quando se joga pela Internet.

$\begin{array}{llllllllllll}0 & 1 & 2 & 3 & 4 & 5 & 6 & 7 & 8 & 9 & 10 & \text { Não tenho opinião }\end{array}$

11.13 Cenários de vários lugares ao redor do mundo por onde podemos passar durante o jogo.

$\begin{array}{llllllllllll}0 & 1 & 2 & 3 & 4 & 5 & 6 & 7 & 8 & 9 & 10 & \text { Não tenho opinião }\end{array}$

11.14 Poder jogar com gente de qualquer parte do mundo pela internet.

$\begin{array}{llllllllllll}0 & 1 & 2 & 3 & 4 & 5 & 6 & 7 & 8 & 9 & 10 & \text { Não tenho opinião }\end{array}$

12. Quanto à história do jogo (narrativas digitais) .

Agora gostaríamos de saber como você se sente com relação ao prazer de acompanhar a história do jogo.

Para isso você deverá indicar o quanto cada uma das situações listadas abaixo é interessante, numa escala de 0 a 10 , sendo que 0 representa algo completamente sem interesse e 10 algo muito interessante e prazeroso. Se você não tiver opinião sobre alguma das situações, marque a opção "Não tenho opinião".

12.1 Jogar num lugar virtual onde podemos usar nossa imaginação e viver nossas fantasias.

$\begin{array}{llllllllllll}0 & 1 & 2 & 3 & 4 & 5 & 6 & 7 & 8 & 9 & 10 & \text { Não tenho opinião }\end{array}$

12.2 Sensação de ser transportado para um lugar virtual onde desejamos estar.

$\begin{array}{llllllllllll}0 & 1 & 2 & 3 & 4 & 5 & 6 & 7 & 8 & 9 & 10 & \text { Não tenho opinião }\end{array}$

12.3 Experimentar na tela do computador imagens e sons de qualidade que dão a impressão de estar no mundo real.

$\begin{array}{llllllllllll}0 & 1 & 2 & 3 & 4 & 5 & 6 & 7 & 8 & 9 & 10 & \text { Não tenho opinião }\end{array}$

12.4 Assumir o papel de um personagem do jogo mostrado na tela do computador, como se você fosse o próprio sujeito. Por exemplo, no jogo Counter-Strike.

$\begin{array}{llllllllllll}0 & 1 & 2 & 3 & 4 & 5 & 6 & 7 & 8 & 9 & 10 & \text { Não tenho opinião }\end{array}$

12. Assumir o papel de um personagem do jogo podendo acompanhar como se fosse outra pessoa olhando para ele. Por exemplo, no jogo The Sims. 
$\begin{array}{llllllllllll}0 & 1 & 2 & 3 & 4 & 5 & 6 & 7 & 8 & 9 & 10 & \text { Não tenho opinião }\end{array}$

12.6 Possibilidade de não revelarmos nossa verdadeira identidade quando jogamos pela Internet.

$\begin{array}{llllllllllll}0 & 1 & 2 & 3 & 4 & 5 & 6 & 7 & 8 & 9 & 10 & \text { Não tenho opinião }\end{array}$

12.7 Efeito de sentir-se parte do universo virtual do jogo mantendo sua integridade no mundo real. Como exemplo, você pode morrer no jogo mas não na vida real.

$\begin{array}{llllllllllll}0 & 1 & 2 & 3 & 4 & 5 & 6 & 7 & 8 & 9 & 10 & \text { Não tenho opinião }\end{array}$

12.8 A possibilidade de ter algum tipo de troca on-line com outros participantes dos jogos. Por exemplo, compartilhar informações importantes para a evolução do jogo.

$\begin{array}{llllllllllll}0 & 1 & 2 & 3 & 4 & 5 & 6 & 7 & 8 & 9 & 10 & \text { Não tenho opinião }\end{array}$

13. Agora vamos olhar como você se sente em relação a quanto você pode interferir no andamento do jogo.

Para isso você deverá indicar o quanto cada uma das situações listadas abaixo é interessante, numa escala de 0 a 10 , sendo que 0 representa algo completamente sem interesse e 10 algo muito interessante e prazeroso. Se você não tiver opinião sobre alguma das situações, marque a opção "Não tenho opinião".

13.1 A possibilidade de escolha e decisão permitidas pelo jogo.

$\begin{array}{llllllllllll}0 & 1 & 2 & 3 & 4 & 5 & 6 & 7 & 8 & 9 & 10 & \text { Não tenho opinião }\end{array}$

13.2 Passar por caminhos surpreendentes.

$\begin{array}{llllllllllll}0 & 1 & 2 & 3 & 4 & 5 & 6 & 7 & 8 & 9 & 10 & \text { Não tenho opinião }\end{array}$

13.3 A qualidade dos efeitos especiais (explosões, tiros, chutes ao gol etc) dando realismo a suas ações no jogo.

$\begin{array}{llllllllllll}0 & 1 & 2 & 3 & 4 & 5 & 6 & 7 & 8 & 9 & 10 & \text { Não tenho opinião }\end{array}$

13.4 Percorrer um labirinto envolvendo a situação de ter que encontrar uma saída com o risco de se deparar com algo inesperado, assustador e desconhecido.

$\begin{array}{llllllllllll}0 & 1 & 2 & 3 & 4 & 5 & 6 & 7 & 8 & 9 & 10 & \text { Não tenho opinião }\end{array}$

13.5 Sentir que a história do jogo está evoluindo.

$\begin{array}{llllllllllll}0 & 1 & 2 & 3 & 4 & 5 & 6 & 7 & 8 & 9 & 10 & \text { Não tenho opinião }\end{array}$

13.6 Encontrar soluções para situações sem saída.

$\begin{array}{llllllllllll}0 & 1 & 2 & 3 & 4 & 5 & 6 & 7 & 8 & 9 & 10 & \text { Não tenho opinião }\end{array}$

13.7 Poder aplicar o raciocínio do mundo real no mundo virtual para resolução de quebra-cabeça.

$\begin{array}{llllllllllll}0 & 1 & 2 & 3 & 4 & 5 & 6 & 7 & 8 & 9 & 10 & \text { Não tenho opinião }\end{array}$

13.8 Viver uma experiência parecida com a do dia-a-dia descobrindo um enigma/lógica.

$\begin{array}{llllllllllll}0 & 1 & 2 & 3 & 4 & 5 & 6 & 7 & 8 & 9 & 10 & \text { Não tenho opinião }\end{array}$

13.9 Viver uma experiência parecida com a do dia-a-dia reconstruindo uma história.

$\begin{array}{llllllllllll}0 & 1 & 2 & 3 & 4 & 5 & 6 & 7 & 8 & 9 & 10 & \text { Não tenho opinião }\end{array}$

13.10 Viver uma experiência parecida com a do dia-a-dia recebendo uma recompensa pela minha coragem. 
\begin{tabular}{|llllllllllll}
\hline 0 & 1 & 2 & 3 & 4 & 5 & 6 & 7 & 8 & 9 & 10 & Não tenho opinião
\end{tabular}

13.11 Viver uma experiência parecida com a do dia-a-dia triunfando sobre um forte oponente.

$\begin{array}{llllllllllll}0 & 1 & 2 & 3 & 4 & 5 & 6 & 7 & 8 & 9 & 10 & \text { Não tenho opinião }\end{array}$

13.12 Viver uma experiência parecida com a do dia-a-dia ganhando bens valiosos ou eliminando bens indesejáveis.

$\begin{array}{llllllllllll}0 & 1 & 2 & 3 & 4 & 5 & 6 & 7 & 8 & 9 & 10 & \text { Não tenho opinião }\end{array}$

13.13 Vencer um obstáculo.

$\begin{array}{llllllllllll}0 & 1 & 2 & 3 & 4 & 5 & 6 & 7 & 8 & 9 & 10 & \text { Não tenho opinião }\end{array}$

13.14 Sobreviver a uma derrota inevitável.

$\begin{array}{llllllllllll}0 & 1 & 2 & 3 & 4 & 5 & 6 & 7 & 8 & 9 & 10 & \text { Não tenho opinião }\end{array}$

13.15 Escolher e modificar o cenário do jogo. Por exemplo, o mesmo jogo pode ser jogado em uma floresta, um deserto ou uma montanha.

$\begin{array}{llllllllllll}0 & 1 & 2 & 3 & 4 & 5 & 6 & 7 & 8 & 9 & 10 & \text { Não tenho opinião }\end{array}$

13.16 Dominar uma situação complicada. Por exemplo, simuladores de vôos e submarinos.

$\begin{array}{llllllllllll}0 & 1 & 2 & 3 & 4 & 5 & 6 & 7 & 8 & 9 & 10 & \text { Não tenho opinião }\end{array}$

13.17 Dar vida a objetos imaginários.

$\begin{array}{llllllllllll}0 & 1 & 2 & 3 & 4 & 5 & 6 & 7 & 8 & 9 & 10 & \text { Não tenho opinião }\end{array}$

13.18 Enfatizar ou simular alguns limites. Por exemplo, dirigir a velocidades extremas na neve.

$\begin{array}{llllllllllll}0 & 1 & 2 & 3 & 4 & 5 & 6 & 7 & 8 & 9 & 10 & \text { Não tenho opinião }\end{array}$

13.19 Construir e manter situações de poder e controle sobre outros personagens. Por exemplo, ser o prefeito ou uma autoridade num jogo em uma cidade.

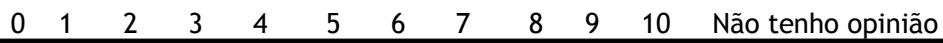

14. Nesta última etapa, vamos olhar como você se sente com relação à sensação de fazer parte da história do jogo ao invés de apenas assisti-la.

Para isso você deverá indicar o quanto é interessante cada uma das situações listadas abaixo, numa escala de 0 a 10 , sendo que 0 representa algo completamente sem interesse e 10 algo muito interessante e prazeroso. Se você não tiver opinião sobre alguma das situações, marque a opção "Não tenho opinião".

14.1 Interferir na história do jogo ao invés de simplesmenteacompanhá-la.

$\begin{array}{lllllllllll}0 & 1 & 2 & 3 & 4 & 5 & 6 & 7 & 8 & 9 & 10\end{array}$ Não tenho opinião

14.2 Poder experimentar uma mesma situação de jogo de formas diferentes. Como exemplo, nos jogos de luta podemos ser um lutador diferente a cada vez que reiniciamos o jogo (forte, fraco, homem, mulher etc).

$\begin{array}{llllllllllll}0 & 1 & 2 & 3 & 4 & 5 & 6 & 7 & 8 & 9 & 10 & \text { Não tenho opinião }\end{array}$

14.3 Sentir a experiência do jogo como se fosse uma experiência pessoal. Por exemplo, podemos sentir o prazer da vitória do personagem como conquista pessoal.

$\begin{array}{llllllllllll}0 & 1 & 2 & 3 & 4 & 5 & 6 & 7 & 8 & 9 & 10 & \text { Não tenho opinião }\end{array}$ 
14.4 Poder adquirir novas habilidades como o aprendizado de línguas, tomada de decisões, simuladores de vôos etc.

$\begin{array}{llllllllllll}0 & 1 & 2 & 3 & 4 & 5 & 6 & 7 & 8 & 9 & 10 & \text { Não tenho opinião }\end{array}$

14.5 Aprender formas de estar no mundo, por exemplo, como resolver conflitos, como ter sucesso na busca por um emprego, como educar bem os filhos, como ser melhor pai ou como se relacionar melhor com os amigos.

$\begin{array}{llllllllllll}0 & 1 & 2 & 3 & 4 & 5 & 6 & 7 & 8 & 9 & 10 & \text { Não tenho opinião }\end{array}$

14.6 Compreender melhor temas polêmicos e injustiças sociais como preconceitos e políticas internacionais.

$\begin{array}{llllllllllll}0 & 1 & 2 & 3 & 4 & 5 & 6 & 7 & 8 & 9 & 10 & \text { Não tenho opinião }\end{array}$

14.7 Estar sempre à procura por informações secretas e recompensas difíceis de serem conseguidas.

$\begin{array}{llllllllllll}0 & 1 & 2 & 3 & 4 & 5 & 6 & 7 & 8 & 9 & 10 & \text { Não tenho opinião }\end{array}$

14.8 Vivenciar uma visão profundamente divertida da vida.

$\begin{array}{llllllllllll}0 & 1 & 2 & 3 & 4 & 5 & 6 & 7 & 8 & 9 & 10 & \text { Não tenho opinião }\end{array}$

14.9 Poder experimentar várias situações de erros até encontrar uma solução satisfatória na história do jogo.

$\begin{array}{llllllllllll}0 & 1 & 2 & 3 & 4 & 5 & 6 & 7 & 8 & 9 & 10 & \text { Não tenho opinião }\end{array}$

14.10 Poder anular a morte. Por exemplo, o nosso personagem morre numa determinada fase do jogo e nós reiniciamos o mesmo jogo em uma fase anterior.

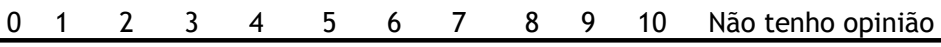

15. Agora, gostaríamos que você comentasse qualquer outro aspecto não mencionado no questionário que você julga como sendo um fator importante também.

16. Este espaço é para que você comente livremente o tema desta pesquisa - Jogos, Prazeres e Narrativas Interativas. Suas experiências, impressões e sugestões são importantes para que possamos conhecer e melhorar nossos serviços. 